
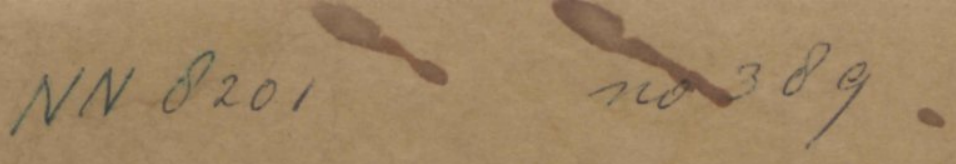

;

An analysis of actual evapotranspiration

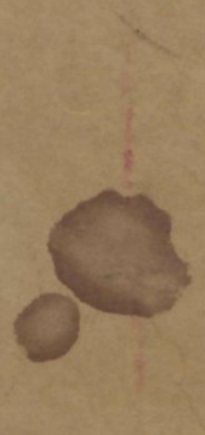

P. E. RIJTEMA

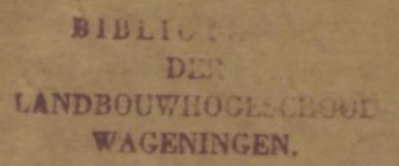


An analysis of actual evapotranspiration 
Dit proefschrift met stellingen van Peter Emile Rijtema landbouwkundig ingenieur, geboren te Hoorn, 19 december 1929, is goedgekeurd door de promotor ir. F. Hellinga

hoogleraar in de cultuurtechniek

De Rector Magnificus van de Landbouwhogeschool W. F. EIJSVOOGEL

Wageningen, 13 mei 1965 


\section{An analysis of actual evapotranspiration}

\section{PROEFSCHRIFT}

TER VERKRIJGING VAN DE GRAAD

VAN DOCTOR IN DE LANDBOUWKUNDE

OP GEZAG VAN DE RECTOR MAGNIFICUS IR. W. F. EIJSVOOGEL, HOOGLERAAR IN DE HYDRAULICA, DE BEVLOEIING, DE WEG- EN WATERBOUWKUNDE EN DE BOSBOUWARCHITECTUUR,

TE VERDEDIGEN TEGEN DE BEDENKINGEN

VAN EEN COMMISSIE UIT DE SENAAT

VAN DE LANDBOUWHOGESCHOOL TE WAGENINGEN

OP WOENSDAG, 30 JUNI 1965 TE 16 UUR

DOOR

P. E. RIJTEMA

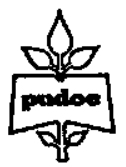

Centrum voor landbouwpublikaties en landbouwdocumentatie Wageningen 1965 
Aan mijn ouders Aan mijn vrouw 
De modelproeven van TING en Loomis mogen niet worden gebruikt voor de berekening van het effect van de gedeeltelijke sluiting van de huidmondjes op de reductie van de verdamping, wegens de grote variatie in de diffusieweerstand voor het damptransport tussen het verdampend oppervlak en de geperforeerde plaat in de opeenvolgende proeven.

TING, I. P. and W. E. Looms, 1963. Diffusion through stomates. Am. J. Bot. 50: 866-872.

De invloed van het randeffect op de verdamping uit lysimeters wordt door MAKKINK overschat, omdat bij de berekening van de extra ontvangen straling het gewas niet als een volkomen gesloten voor licht ondoorlatend oppervlak mag worden beschouwd.

Makxnnx, G. F., 1957. Testing the Penman formula by means of lysimeters. J. Inst. Water Eng. 11: 277-288.

\section{III}

De betekenis van de capillaire opstijging in zandgrond in verband met de vochtvoorziening van gewassen wordt vaak onderschat.

WInd, G. P. and A. P. HidDing, 1961. The soil physical basis of the improvement of clay cover soils. Neth. J. Agric. Sci. 9: 281-292.

\section{IV}

De juistheid van de door DE WIr gegeven relaties tussen verdamping en opbrengst moet ernstig in twijfel worden getrokken.

WIT, C. T. DE, 1958. Transpiration and crop yields. Versl. Landbouwk. Onderz. 64.6.

\section{V}

De door GaASTRA gevolgde berekeningswijze voor te bepaling van de diffusieweerstand voor $\mathrm{CO}_{2}$-transport in het blad leidt tot te hoge waarden van deze weerstand.

GaAstra, P., 1959 Photosynthesis of crop plants as influenced by light, carbon dioxide, temperature and stomatal diffusion resistance. Med. Landbouwhogeschool 59.13. 
Het door VAN DUIN en door WESSELING op grond van literatuurgegevens aangenomen lineaire verband tussen de diffusiecoëfficiënt voor gas en het met lucht gevulde poriënvolume in de grond is aanvechtbaar.

Duin, R. H. A. vaN, 1956. Over de invloed van grondbewerking op het transport van warmte, lucht en water in de grond. Versl. Landbouwk. Onderz. 62.7.

Wesseling, J., 1962. Some solutions of the steady state diffusion of carbon dioxide through soils. Neth. J. Agric. Sci. 10: 109-117.

\section{VII}

De door HoffMaN en SchwaB voorgestelde methode voor het bepalen van de drainafstand uit de gemeten drainafvoeren met behulp van drie drains in een overigens niet gedraineerd gebied is voor de praktijk niet toepasbaar.

Hofrman, G. J. and G. O. SchwaB, 1964. Tile spacing prediction based on drain outflow. Trans. Am. Soc. Agric. Eng. 7: 444-447.

\section{VIII}

Ten onrechte wordt bij het ontwerpen van waterlopen uitgegaan van de veronderstelling dat de formule van MANNING onder alle omstandigheden mag worden toegepast.

WERKGROeP WATERLOPEN, 1958. Richtlijnen voor het ontwerpen van open waterlopen en van sommige bijbehorende kunstwerken.

Engelund, F., 1964. Flow resistance and hydraulic radius. Acta Polytechn. Scandinavia series 24.

\section{IX}

De opbrengstdepressie tengevolge van vochttekorten wordt onder de Nederlandse klimatologische omstandigheden in droge jaren, bij vergelijking met de opbrengst in ,normale" jaren, onderschat.

Verslag over de landbouw in Nederland over 1959. Versl. en Meded. Min. L.V, 1961 no. I BERG, C. VAN DEN, 1962. Enige landbouwkundige aspecten van de droogte in 1959. Versl. en Meded. Comm. Hydr. Onderz. T.N.O. 7: 107-126.

\section{$\mathbf{X}$}

De opbrengstdepressie van grasland tengevolge van optredende vochttekorten moet naast de sluiting van de huidmondjes in belangrijke mate worden toegeschreven aan de vertraging in de lengtegroei van het gewas. 
Het is onjuist bij de berekening van de verdamping van een vrij wateroppervlak en van gewassen met behulp van een gecombineerde methode gebruik te maken van de gemiddelde overdag-waarden van temperatuur en luchtvochtigheid.

\section{XII}

Als standaard verdampingspan moet aan de ondiepe ingegraven pan de voorkeur worden gegeven boven de U.S. Weather Bureau Class A pan.

\section{XIII}

Voor degenen, die geboren zijn tussen 1 oktober en 31 december en die een akademische studie gaan volgen, is de thans geldende regeling voor uitstel van eerste oefening in militaire dienst veel ongunstiger dan voor hen, die geboren zijn tussen 1 januari en 30 september. De in deze regeling gestelde tijdgrenzen dienen, ter vermijding van onbillijkheid, in overeenstemming te worden gebracht met de geldende tijdgrens voor de leerplicht van het lager onderwijs.

Proefschrift P. E. Rutema

Wageningen, 30 juni 1965. 


\section{Voorwoord}

Bij het afsluiten van dit proefschrift neem ik gaarne de gelegenheid te baat mijn dank uit te spreken aan allen die tot de voltooiing hiervan hebben bijgedragen.

Hooggeleerde Hellinga, hooggeachte promotor, $U$ in het bijzonder ben ik dank verschuldigd, Uw belangstelling voor dit onderzoek is een grote stimulans geweest. Uw kricische opmerkingen hebben mede de vorm en de inhoud van dit proefschrift bepaald.

Hooggeleerde VAN WiJK, $U$ dank ik voor de waardevolle discussie die ik tijdens de voltooiing van dit proefschrift met $U$ mocht hebben.

Hooggeleerde VAN DEN BERG, weledelgestrenge VISSER, ik dank U, dat U als directeur en als adjunct-directeur van het Instituut voor Cultuurtechniek en Waterhuishouding mij in de gelegenheid hebt gesteld dit onderzoek met een grote mate van vrijheid te verrichten.

Waarde PANKow, waarde RYhINeR en waarde SchWARZ, onder degenen die aan het verzamelen en uitwerken van de gegevens hebben medegewerkt, mogen Uw namen niet onvermeld blijven. Ik ben $U$ zeer veel dank verschuldigd voor Uw enthousiaste medewerking en $\mathrm{Uw}$ waardevolle steun bij de uitvoering van de metingen en de berekeningen.

Waarde BIERHUIZEN, waarde WesseLING, jullie kritische opmerkingen en waardevolle adviezen zijn voor mij een grote steun geweest bij de voltooiing van dit proefschrift.

Waarde VAN 'T LEVEN, ik ben je zeer erkentelijk voor het beschikbaar stellen van gegevens uit Tunesië.

Waarde SCHIERBEEK, ik ben je zeer veel dank verschuldigd voor de wijze waarop je de Engelse tekst hebt willen corrigeren. Je waardevolle hulp bij de redactie van het manuscript en de figuren heeft in belangrijke mate een stempel gezet op de uitvoering van dit proefschrift.

Zeer geachte heer KLAASSEN, zeer geachte heer KüHN, zeer geachte heer ARIESE, gaarne wil ik mijn dank uitspreken voor de voortreffelijke uitvoering van de figuren.

De leden van de Werkgroep Lysimeters T.N.O. en van de Werkcommissie voor Verdampingsonderzoek dank ik voor de prettige samenwerking, die ik met hen in de afgelopen jaren mocht hebben. Ik hoop dat dit proefschrift een bijdrage mag zijn tot ons gezamenlijk onderzoek.

Weledelgestrenge Maltha, $U$, als directeur van het Centrum voor Landbouwpublicaties en Landbouwdocumentatie, dank ik voor het opnemen van mijn proefschrift in de Verslagen van Landbouwkundige Onderzoekingen.

De Heer M. J. M. Osse van dit Centrum ben ik erkentelijk voor zijn typografische adviezen. 
This thesis is also published as Agricultural Research Reports 659 


\section{Contents}

$\begin{array}{ll}\text { I. INTRODUCTION } & 1\end{array}$

II. INSTRUMENTS AND OBSERVATIONS 4

1. Lysimeters 4

2. Precipitation 5

3. Pan evaporation 6

4. Meterological observations 7

5. Crop height $\quad 7$

6. Moisture content $\quad 7$

7. Soil temperature $\quad 8$

8. Interception 9

Summary 9

III. METEOROLOGICAL ASPECTS OF EVAPOTRANSPIRATION 10

1. Turbulent vapour transport $\quad 10$

2. Energy balance 15

2.1. Shortwave radiation 15

2.2. Reflection coefficient 16

2.3 Net longwave radiation $\quad 17$

2.4. Sharing of net radiation 18

3. Combined aerodynamic and energy balance methods 22

3.1. Method of Penman 22

3.2. Method of Mcllroy 23

3.3. Discussion of the combined methods 24

4. Comparison of calculated evaporation from a free water surface with measured pan evaporation $\quad 25$

5. Influence of advection on evapotranspiration 27

$\begin{array}{ll}\text { Summary } & 29\end{array}$

IV. Plant physiological aspects OF eVAPOTRANSPIRATION 31

1. Water transport in plants

1.1. Resistance in the leaf tissue 32

1.2. Resistance in the root cells 32

2. Effect of stomatal opening on evapotranspiration 33

2.1. Effect of light intensity 34

2.2. Effect of leaf temperature 35 
3. Reduction factor of Penman 35

4. Effect of interception on evapotranspiration 39

Summary $\quad 42$

V. SOIL PHYSICAL ASPECTS OF EVAPOTRANSPIRATION 44

1. Capillary conductivity of soils 44

2. Extraction of water from the profile 51

2.1. Effect of suction and capillary conductivity on the extraction by uniform root systems 52

2.2. Effect of suction and capillary conductivity on the extraction by nonuniform root systems

3. Moisture extraction from the soil by grass 55

3.1. Moisture extraction from the root zone 56

3.2. Moisture extraction from below the root zone 59

4. Effect of soil factors on the apparent diffusion resistance of crops 65

Summary $\quad 69$

VI. ANALYSIS OF EVAPOTRANSPIRATION DATA 71

1. Procedure of the analysis 71

2. Determination of the unknown factors under conditions of optimum water supply $\quad 75$

2.1. Reflection coefficient 76

2.2. Roughness function 76

2.3. Apparent diffusion resistance of grass with optimum water supply 78

3. Influence of local advection on evapotranspiration 79

4. Effect of the water supply in the effective root zone on evapotranspiration 80

5. Calculation of crop factors in relation to evaporation 86

Summary $\quad 90$

$\begin{array}{lr}\text { SUMMARY } & 92\end{array}$

$\begin{array}{lr}\text { SAMENVATtING } & 94\end{array}$

$\begin{array}{lr}\text { LIST OF SYMBOLS } & 99\end{array}$

$\begin{array}{ll}\text { REFERENCES } & 102\end{array}$ 


\section{Introduction}

Evapotranspiration is the loss of water in vapour state from a cropped soil to the atmosphere. This water loss includes the vaporization from the upper soil layers (evaporation) and the vaporization of water taken from the soil by plants (transpiration). For the vaporization of intercepted precipitation (or sprinkling water) and dew from plant surfaces the term evaporation is also applied, just as for the vaporization of water from free water surfaces.

The evaporation from free water surfaces is dependent only on meteorological factors as radiation, temperature, relative humidity and wind velocity. The evapotranspiration from a cropped soil is not only dependent on these meteorological factors but also on factors related to the crop and to the available amount of moisture in the soil. For this reason the concept of potential evapotranspiration has been introduced; it is defined as the rate of evapotranspiration dependent on weather conditions, from an extensive surface of a short green crop of uniform height, completely shading the soil and actively growing under conditions of optimum water supply (PENMAN, $1948 ; 1956)$. In order to calculate the evapotranspiration from a certain crop with other specifics, the potential value must be multiplied by a crop factor (MAKKINK, 1960; MAKKinK and VAN HeEmSt, 1962).

A number of methods have been evolved to calculate the potential evapotranspiration. Some of these methods are based on an empirical correlation with the mean monthly air temperature (ThorNTHWarte, 1948; BLANEY and CriddLe, 1950). MaKKINK (1955) has shown that the curve of the monthly values over the year based on the formula of Thornthwaite, only agrees under the conditions prevailing in the Netherlands with the observed potential evapotranspiration if a correction for a time lag and for the wind velocity is applied. No method based on monthly temperature alone, can be expected to give reliable results for climatologically different regions (VAN WIJK a.o., 1953).

It can also be expected that empirical formulae, as for example presented by TURC (1954; 1955), not related to the physical processes determining evapotranspiration, give unreliable results under conditions different from the ones they are based on. Penman (1948) evolved a method based on an approximation of the energy balance. Generally speaking this method gives better results than methods based on a correlation with mean monthly temperature.

Due to the development of the crop and to a possible lack of water, the evapotranspiration has under many conditions no direct relation with the evaporation from a free water surface. It is therefore necessary to take all the factors governing the 
real evapotranspiration into account. The most important factors determining the rate of evapotranspiration are:

a. the transport of water vapour from the air layers close to the evaporating surface to higher layers;

b. the amount of energy available for the vaporization of water;

c. the aperture of the stomata in connection with the diffusion of water vapour through them;

d. the rate of the supply of water to the evaporating surface.

The factors given under $a$ and $b$ are dependent on the meteorological conditions also governing the loss of water from a free water surface, although they differ for a crop since there is a difference in roughness and reflection of the evaporating surface. The factors $\mathrm{c}$ and $\mathrm{d}$ are plant physiological and soil physical ones.

Each of the mentioned factors may act as a limiting factor for the evapotranspiration. These factors are taken into account and related to each other in the present study, resulting in formulae for the calculation of actual evapotranspiration under the conditions prevailing.

In Chapter II a review will be given of the instruments and the observations used in the present study.

The climatological aspects of evapotranspiration are discussed in Chapter III. This Chapter also deals with the meaning of measured pan evaporation and the influence of local advection on evaporation.

In Chapter IV some plant physiological aspects will be treated. Aside from a discussion on the reduction factor of PENMAN (1948; 1956) attention will be given to the influence of light intensity on the stomatal opening in connection with transpiration. Also the effect of the interception of precipitation on evapotranspiration is dealt with.

Some soil physical aspects are discussed in Chapter V. Data on capillary conductivity are examined and a calculation model concerning the transport resistances in the root zone and in the plant is presented. Data on the capillary rise from a groundwater table are also given.

Finally, in Chapter VI the results of the analysis of the evapotranspiration data of lysimeters are presented in relation to the considerations given in the preceding chapters. Attention will also be given to the significance of crop factors in relation to the evaporation from a free water surface. The possibility to calculate these factors for different climatological conditions is discussed. 
The main instrument used, is an installation of lysimeters situated near Wageningen. The investigations with lysimeters in the Netherlands are coordinated in the Working Party on Lysimeters of the Committee on Hydrological Research T.N.O.. Part of the results of these investigations and a description of the lysimeters used in the Netherlands was given by WIND $(1958 ; 1960)$. The observations with the installation, used in the present study, were started in 1952 by MAKKINK (see for example 1962) of the former Central Institute for Agricultural Research. Since the reorganization in 1957 of agricultural research in the Netherlands, the present author became responsible for this installation. Although for this reason the data obtained from these lysimeters will be used in particular, the present study can be regarded as a contribution to the activities of the Working Party on Lysimeters. 


\section{Instruments and Observations}

\section{Lysimeters}

The evapotranspiration of grass was determined under various conditions of water management from water balances of 32 lysimeters in the neighbourhood of Wageningen, the Netherlands. The installation is situated in an extensive grass area, in general well supplied with water. A full description of the construction and the equipment of these lysimeters was given by MaKKINK $(1953 ; 1962)$.

The lysimeters contain undisturbed soil profiles, coming from areas with a heavy clay soil (12 lysimeters), respectively a peat soil (12 lysimeters) and a loamy sand (8 lysimeters). The soils can be regarded as representative for the grassland areas in the Netherlands. The soil moisture characteristics of the different layers in the profiles are presented in figure 1 .

Each lysimeter has an overflow (MARIOTTE-system) to ensure a constant water table as target-level. The real depth of the groundwater table varied within narrow limits around the target-level. The target-levels of the different lysimeters are given in table 1. The figures in brackets give the number of lysimeters with the same level.

Table 1. Target-levels of the groundwater table in the lysimeters in $\mathrm{cm}$ below surface

\begin{tabular}{ccc}
\hline Sand & Peat & Clay \\
$50(4)$ & $50(2)$ & $50(2)$ \\
$60(2)$ & $60(2)$ & $70(2)$ \\
$100(1)$ & $70(2)$ & $90(2)$ \\
$125(1)$ & $90(2)$ & $100(2)$ \\
& $100(2)$ & $125(2)$ \\
& $125(2)$ & $145(2)$ \\
\hline
\end{tabular}

Daily readings were made of the amount of drainage from each lysimeter. During dry periods water was supplied automatically from calibrated bottles to the lysimeters. All data were taken between 8.00 and $9.00 \mathrm{a} . \mathrm{m}$. The change in soil moisture was measured by periodically weighing the lysimeters. From April 1 to October 1 the lysimeters were weighed two times a week and during the winter half-year once a week. The weighings were performed directly after taking the other data, of which more below. 

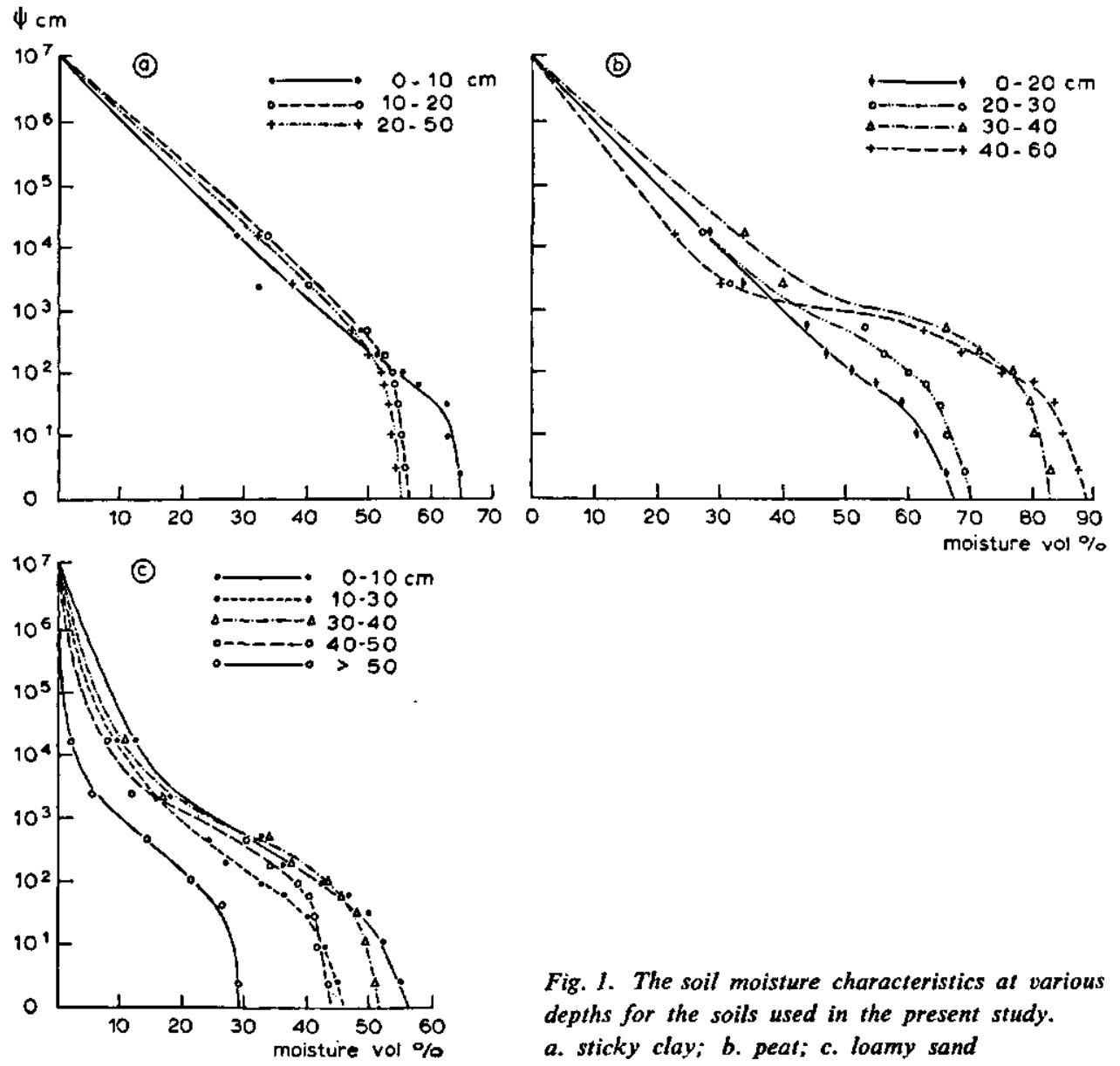

Fig. 1. The soil moisture characteristics at various depths for the soils used in the present study. a. sticky clay; b. peat; c. loamy sand

\section{Precipitation}

The precipitation in the preceding 24 hours was measured every day between 8.00 and $9.00 \mathrm{a} . \mathrm{m}$. Four rain gauges were installed at the lysimeter station. Two of them were exposed at $40 \mathrm{~cm}$ above soil surface (standard height in the Netherlands), while the others were placed with their rim at surface height. The measured amounts of precipitation did show systematic differences dependent on the height of exposure and on wind velocity. The ratio $P_{0} / P_{40}$ in relation to wind velocity is presented in figure 2. The data concern amounts of precipitation exceeding $3 \mathrm{~mm} \cdot$ day $^{-1}$. The diagram shows that with increasing wind velocity, the amounts of precipitation measured at the $40 \mathrm{~cm}$ level are smaller than the measured amounts at surface height. Similar results were reported by DE ZEEUW (1963) in a study concerning the measurement of precipitation. For this reason the amounts of rain measured at surface height were used when calculating evapotranspiration from water balances. In summer 
periods, under conditions of heavy rain and high wind velocity, the water balance of the lysimeters yielded negative values of evapotranspiration, even when the amounts of precipitation measured at surface height were used in the calculation.

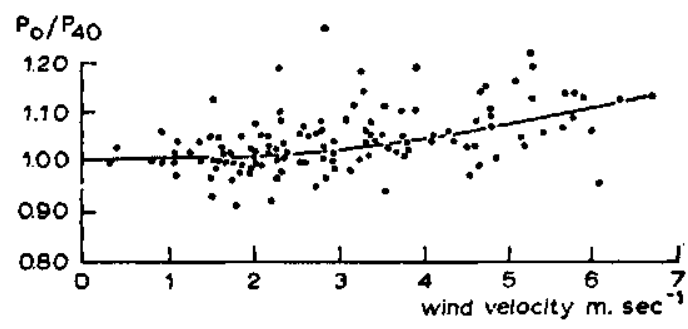

Fig. 2. Relation between the ratio $P_{0} / P_{40}$ and the wind velocity at $2 \mathrm{~m}$ height. The amounts of precipitation exceed $3 \mathrm{~mm}^{-d_{a y}-1}$

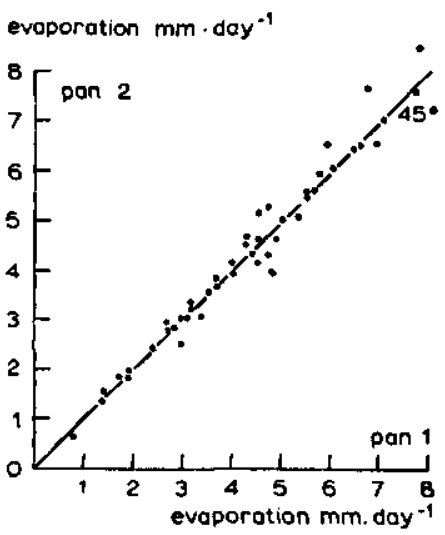

Fig. 3. Relation between evaporation measured from two sunken pans during 45 successive days in 1959. Pan 1 exposed in the field and pan 2 between the rails

This seems to indicate that, under these conditions, even the measured amounts at surface height may be too low.

\section{Pan evaporation}

The evaporation from a free water surface was measured with two sunken pans (diameter $50 \mathrm{~cm}$, depth $25 \mathrm{~cm}$ ). The water surface was kept $2.5 \mathrm{~cm}$ below the rim of

Table 2. Monthly evaporation in mm measured with two sunken pans during the summer half-year. Pan 1 exposed in the field, pan 2 exposed between the rails

\begin{tabular}{lccccccccc}
\hline & & & & & & & & \multicolumn{2}{c}{ Total } \\
\cline { 6 - 9 } Year & Pan & April & May & June & July & August & Sept. & pan 1 & pan 2 \\
1959 & 1 & 49.8 & 109.1 & 141.8 & 149.5 & 98.4 & 88.2 & 636.8 & \\
& 2 & 49.0 & 105.2 & 140.9 & 146.5 & 99.5 & 92.9 & & 634.0 \\
1960 & 1 & 66.8 & 103.0 & 120.6 & 78.5 & 70.9 & 46.9 & 486.7 & \\
& 2 & 68.9 & 106.0 & 119.7 & 80.6 & 70.8 & 45.7 & & 491.7 \\
1961 & 1 & 38.8 & 78.5 & 91.0 & 73.1 & 72.5 & 39.0 & 392.9 & \\
& 2 & 40.5 & 78.4 & 93.1 & 73.4 & 75.1 & 40.7 & & 401.2 \\
1962 & 1 & 52.9 & 64.9 & 98.7 & 87.6 & 87.0 & 62.4 & 453.5 & \\
& 2 & 50.2 & 64.1 & 97.7 & 87.8 & 87.5 & 61.9 & & 449.2 \\
1963 & 1 & 54.8 & 61.1 & 105.6 & 88.6 & 69.9 & 56.9 & 436.9 & \\
& 2 & 55.1 & 59.8 & 104.0 & 87.6 & 71.8 & 51.9 & & 430.2 \\
1964 & 1 & 48.9 & 87.3 & 115.9 & 122.2 & 89.1 & 65.0 & 528.5 & \\
& 2 & 49.8 & 83.8 & 114.0 & 121.4 & 89.7 & 60.5 & & 519.1 \\
\hline
\end{tabular}


the pan, the rim being at the same level as the soil surface. The pans were surrounded by grass cut short. One of the pans was exposed in the field and the other between the rails of the weighing-machine, close to the roof of the observation cellar. Despite the

difference in direct environment the agreement between the measured data, presented in figure 3, was satisfactory. MAKKINK (1957) did mention a similar result with the same outfit. Data of measured monthly pan evaporation during the summer halfyear are given in table 2.

\section{Meteorological observations}

Temperature and relative humidity were recorded with a thermohygrograph in a screen at two meters at the lysimeterstation. The instrument was checked daily by comparison with a ventilated psychrometer. Maximum and minimum temperatures were also measured.

The mean wind velocity was measured at a height of two meters with two totalizing cup-anemometers connected with mechanical counters.

In calculating evapotranspiration, data concerning solar radiation and the duration of bright sunshine were used that were measured by the Department of Physics and Meteorology of the Agricultural University at Wageningen. The meteorological observation field is situated at approximately $3 \mathrm{~km}$ from the lysimeter station.

\section{Crop height}

The height of the grass on the lysimeters was measured on the days that the containers were weighed. On each lysimeter, this height was measured at 12 spots. As crop height during the water balance period, the mean was taken of the measurements at the beginning and at the end of the period. Balance periods in which the grass was cut, were not taken into consideration, because of the discontinuity in height. The grass was cut once in five weeks.

\section{Moisture content}

During three years, the variation in moisture content was next to weighing of the lysimeters measured with nylon units at various depths. The results of the measurements with nylon units after rewetting of a dry profile were very poor, due to hysteresis effects. It was therefore impossible to measure the moisture distribution during the complete growing season. For a number of periods without precipitation, the loss of moisture from the profile measured with nylon units was practically equal to the loss determined by weighing. The variation in soil moisture determined by both methods during the summer of 1957 in a peat soil is presented in figure 4. During the 
first dry period both methods gave comparable results. Large discrepancies existed after rewetting of the soil. The data earlier presented by MakKINK (1962) gave a

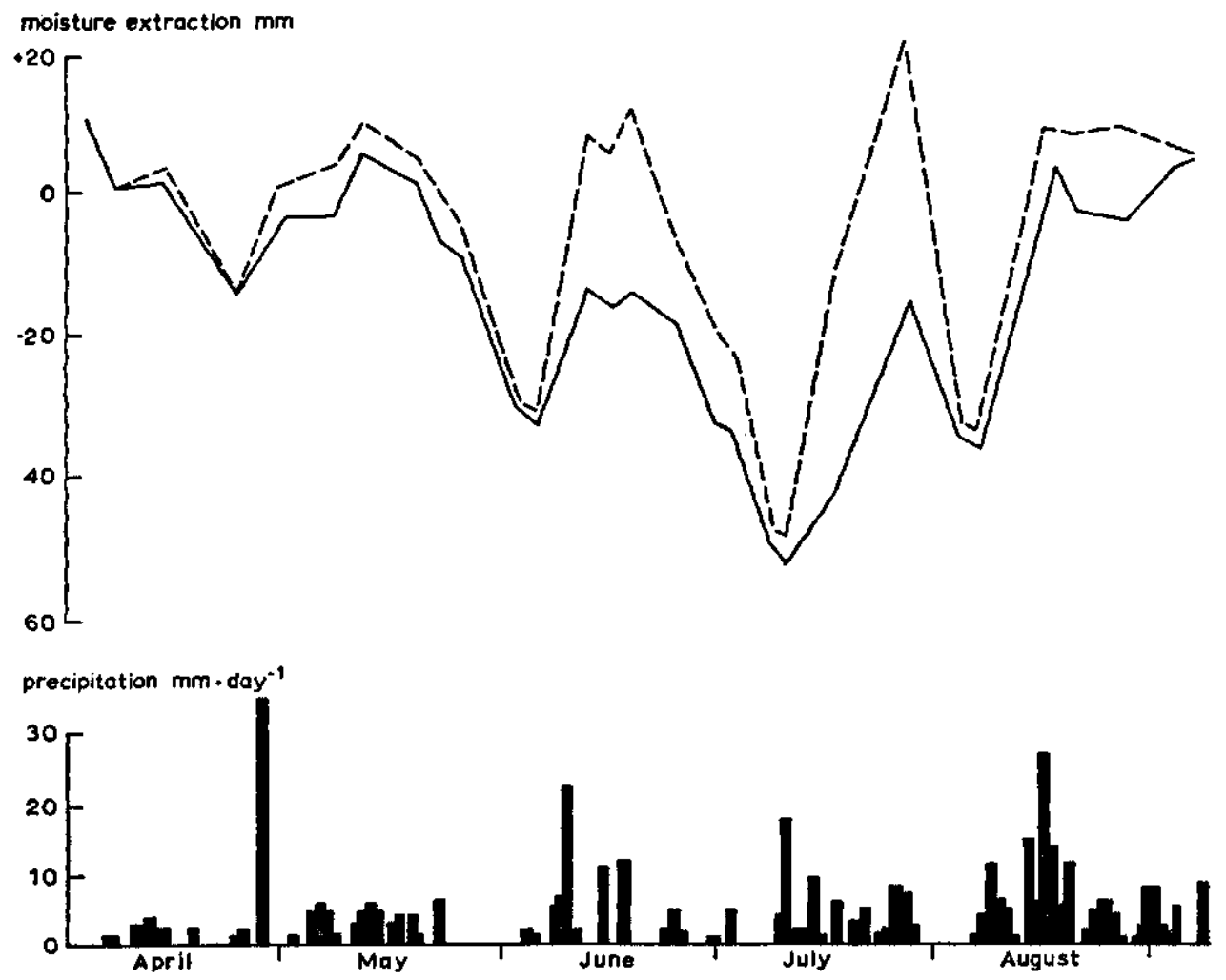

Fig. 4. Variation of total soil moisture in a peat soil measured with nylon units (-- - ) and by weighing of the lysimeter (_- 1957

similar picture. In spite of the difficulties with the nylon units it was possible, however, to draw important conclusions on the moisture distribution in the profile. Also, a number of measurements were used for the calculation of capillary conductivity of the soils.

\section{Soil temperature}

The temperature of the soil in the lysimeters was measured with calibrated thermistors. The data were used to correct for temperature the measurements of the nylon units. Part of the data was used in calculating the heat storage in the soil over the year. 


\section{Interception}

Measurements of the amount of water remaining on the leaf surface of the crop after precipitation, were performed using small containers $(30 \times 30 \times 10 \mathrm{~cm})$ covered with grass. The observations were carried out in the cellar of the lysimeter station in order to prevent evaporation losses as much as possible. After saturating the coarse sand in the containers, they were placed upon a quick-weighing balance. The crop was then given various amounts of water with a small sprinkler. The total amount of water applied was determined by measuring the amount of surface discharge from the soil and by measuring the increase in weight of the container. Under these circumstances, the amount of water intercepted by the crop equals the gain in weight of the container. The results of these experiments are given in Chapter IV.

\section{Summary}

A description is given of the instruments and observation methods used in the present study.

It appeared that the measurements of precipitation at surface level give more reliable data, than those measured at $40 \mathrm{~cm}$ above the surface, due to the turbulence effect of the wind. For this reason the data measured at surface height will be used in the calculation of evapotranspiration from the lysimeters.

In spite of the differences in exposure of the two sunken pans used, a satisfactory agreement between the measured evaporation data was found, indicating that the effect of the rails and the roof of the observation cellar of the lysimeters on evaporation was under the prevailing conditions of minor importance.

Measurements of soil moisture content, when using nylon units, gave, in comparison to weighing of the lysimeters only satisfactory results when no hysteresis effects were present. 


\section{Meteorological aspects of evapotranspiration}

\section{Turbulent vapour transport}

In air without movement or under conditions of laminar flow, the vertical transport of water vapour is determined by molecular diffusion. The layer of laminar flow is in the open under normal conditions very thin. The thickness of this layer is determined by the wind velocity and the roughness of the evaporating surface. Above this boundary layer the vapour transport does not only take place by molecular diffusion but is mainly governed by the irregular turbulent flow of air.

Temperature gradients existing in the air cause a transfer of sensible heat. In the turbulent moving air this transfer is mainly determined by the turbulent flow exchange of warm and colder air.

The turbulent flow of air is under field conditions characterized by a horizontal bulk movement with a mean direction of flow that tends to remain constant over periods longer than those that are to be considered. The velocity in this mean direction is usually symbolized by $\bar{u}$, and over a long period the mean side component $\bar{v}$ and the mean vertical component $\bar{w}$ will be zero. At any given time and place, however, the turbulence of the moving air can be expressed through the eddy-velocities $u^{\prime}, v^{\prime}$ and $w^{\prime}$, representing instantaneous departures from the mentioned means. The vertical eddy-velocities are particularly important for their effect on the vertical transfer of momentum, resulting in the establishment of a vertical profile of horizontal velocities with a zero value at the surface, a rapid increase with height $(z)$ over a short height range and then a more gradual increase.

Analogous to molecular- and other well known transfer processes, the basic equations of mean vertical transfer of momentum, heat and vapour can be written as follows:

$$
\begin{array}{ll}
\text { momentum: } & \tau=\rho K_{M} \frac{\partial u}{\partial z} \\
\text { sensible heat: } & K=-\rho c_{p} K_{H} \frac{\partial T}{\partial z} \\
\text { water vapour: } & E=-\rho K_{V} \frac{\partial q}{\partial z}
\end{array}
$$

where $\rho$ is the air density in $\mathrm{g} \cdot \mathrm{cm}^{-3}, c_{p}$ the specific heat of dry air at constant pressure $\left(0.242 \mathrm{cal} \cdot \mathrm{g}^{-1} \cdot\left({ }^{\circ} \mathrm{C}\right)^{-1}\right), T$ the temperature in ${ }^{\circ} \mathrm{C}$, and $q$ the specific humidity in gram of water vapour per gram of moist air. $K_{M}, K_{H}$ and $K_{V}$ are the eddy-transfer factors in 
$\mathrm{cm}^{2} \cdot \mathrm{sec}^{-1}$ of momentum, heat and water vapour respectively. The subscripts to the $K$-factors are written in these equations in recognition of the fact that the eddytransfer processes, although very similar, are not necessarily identical for each of the properries concerned.

Evapotranspiration can be calculated according to THORNTHWAITE and HolzMAN (1939; 1942) by assuming the following propositions:

a. the transfer factor for momentum is identical with that for water vapour;

b. the shearing stress is constant with height:

$$
\frac{\tau}{\rho}=\frac{\tau_{0}}{\rho}=K_{M} \frac{\partial u}{\partial z}
$$

c. the wind velocity $u_{z}$ at the height $z(z \geqq d)$ may be expressed as:

$$
u_{z}=\frac{1}{k}\left(\frac{\tau_{0}}{\rho}\right)^{\frac{t}{2}} \ln \left(\frac{z+z_{0}-d}{z_{0}}\right)
$$

where $k(\approx 0.4)$ is a turbulence constant originally introduced by Von KARMAN, $z_{0}$ a constant for each surface, known as the roughness length, and $d$ the displacement of the zero plane of wind velocity in relation to the earth surface.

The propositions mentioned before lead to the following equation for evapotranspiration:

$$
E=\frac{\rho k^{2}\left(u_{2}-u_{1}\right)\left(q_{1}-q_{2}\right)}{\left\{\ln \frac{\left(z_{2}+z_{0}-d\right)}{\left(z_{1}+z_{0}-d\right)}\right\}^{2}}
$$

The identity of the eddy-transfer factors of momentum and water vapour was the subject of experimental investigation by PASQUILL (1949a), RIDER and ROBINSON (1951), Rider (1954a), SHEPPARD (1958) and DEACON and Swinbank (1958) and the evidence for this appears to be fairly conclusive.

The constancy of shearing stress with height was first proved on a theoretical base by ERTEL (1933) and has been confirmed by CALDER (1939). According to this theory the deviation of shearing stress at a height of 25 meter should be smaller than $6 \%$ of the corresponding value at a height of 1.5 meter.

Experimental results reported by PASQuill (1950a) did show a greater variation in shearing stress, due to effects of buildings, trees and irregularities in the field at greater distance. The variation in shearing stress at 25 meter height appears, from experimental investigations reported by DEACON (1954), to be greater than at 1.5 meter height. A systematic deviation between the shearing stresses at both heights could, however, not be proved, due to the natural variation of the turbulent flow in the field

Deacon (1949), Pasquill (1949b, 1950b) and Rider (1954a, 1957) have demonstrated that the logarithmic wind function holds for wind flowing over natural surfaces in the open and near the ground, when the atmosphere is neutrally stratified.

DEACON (1949) proposed a power function for the wind profile under non-neutral 
conditions with the general equation:

$$
\frac{\partial u}{\partial z}=a z^{-\beta}
$$

where $\beta$ is a constant depending upon the stability of the atmosphere. DeAcoN presents for grass the following values of $\beta: 0.75$ to $1.0,1.0$ and 1.0 to 1.2 under respectively stable, neutral and unstable conditions of the atmosphere. This general equation for the wind profile leads to the following equation for the wind velocity:

$$
u_{z}=\frac{1}{k(1-\beta)}\left(\frac{\tau_{0}}{\rho}\right)^{\frac{1}{2}}\left[\left(\frac{z+z_{0}-d}{z_{0}}\right)^{1-\beta}-1\right]
$$

Expanding equation (8) in a Taylor series makes the relation to the logarithmic wind function clear:

$$
\begin{aligned}
u_{z}=\frac{1}{k}\left(\frac{\tau_{0}}{\rho}\right)^{\frac{t}{2}} \ln \left(\frac{z+z_{0}-d}{z_{0}}\right)\left\{1+\frac{(1-\beta)}{2 !} \ln \left(\frac{z+z_{0}-d}{z_{0}}\right)+\right. & \\
& \left.+\frac{(1-\beta)^{2}}{3 !} \ln ^{2}\left(\frac{z+z_{0}-d}{z_{0}}\right)+\ldots\right\}
\end{aligned}
$$

Values of $\beta$ are difficult to be exactly determined from measured data of wind velocity. RIDER (1954b) did show that small errors, in the order of $1 \%$, of the measured wind velocity have an enormous influence on the value of $\beta$. His data also make clear the necessity to know the experimentally determined values of $d$ and $z_{0}$ with an accuracy of a few $\mathrm{mm}$, before $\beta$ can be determined with any confidence.
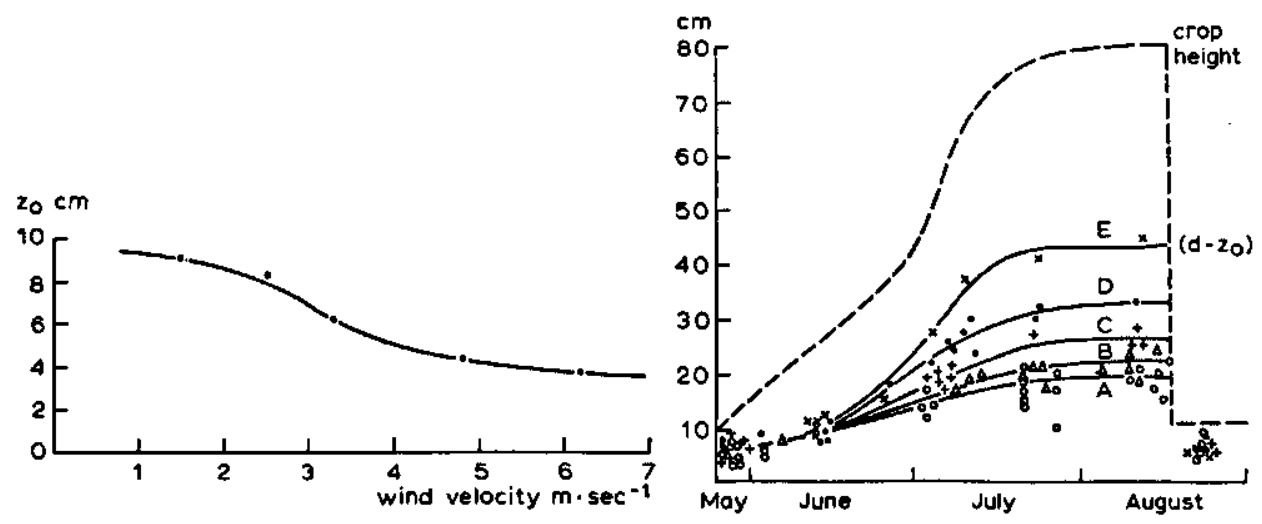

Fig. 5. Relation between the roughness length $\left(z_{0}\right)$ and the wind velocity at $2 \mathrm{~m}$ height for tall grass (60 to $70 \mathrm{~cm}$ ) with a zero-plane displacement (d) of $25 \mathrm{~cm}$ (DeACON, 1949)

Fig. 6. Variation in crop height of oats during the growing season (----) and values of $\left(d-z_{0}\right)(--)$ for various wind velocities at $2 \mathrm{~m}$ height according to RIDER (1954b)
A $u<J \mathrm{~m} \cdot \mathrm{sec}^{-1}$
B $\quad$ I $m \cdot \mathrm{sec}^{-1}<u<2 \mathrm{~m} \cdot \mathrm{sec}^{-1}$
D $3 \mathrm{~m} \cdot \mathrm{sec}^{-1}<u<4 \mathrm{~m} \cdot \mathrm{sec}^{-1}$
C $2 \mathrm{~m} \cdot \mathrm{sec}^{-1}<u<3 \mathrm{~m} \cdot \mathrm{sec}^{-1}$
E $\quad u>4 m \cdot \sec ^{-1}$ 
Both the value of the zero plane displacement $d$ and the value of the roughness length $z_{0}$ are dependent on the wind velocity, because of the bending of the crop. $\because \quad$ The relation between the roughness length of tall grass and wind velocity, from experimental data given by DEACON (1949), is presented in figure 5 , showing a decrease in roughness with increasing wind velocity. Data of $\left(d-z_{0}\right)$ concerning oats under neutral conditions of the atmosphere as reported by RIDER (1954b), also show an influence of wind velocity (figure 6).

Formally, equation (6) only holds under neutral conditions of the atmosphere. Under other conditions a correction will have to be applied. Use of equation (8) yields the following equation for evapotranspiration:

$$
E=\frac{\rho k^{2}(1-\beta)^{2} z_{0}^{2(1-\beta)}\left(u_{2}-u_{1}\right)\left(q_{1}-q_{2}\right)}{\left[\left(z_{2}+z_{0}-d\right)^{1-\beta}-\left(z_{1}+z_{0}-d\right)^{1-\beta}\right]^{2}}
$$

The deviation between the evapotranspiration, as calculated by both methods, becomes smaller when the measurements are performed closer to the evaporating surface. In that case, however, both zero level difficulties and sampling variations are introduced. PASQUILL (1949b) found when measuring during clear spring weather at $50 \mathrm{~cm}$ height above a surface of grass cut short, a systematic deviation of approximately $10 \%$ in the form of an underestimation of evapotranspiration under unstable conditions and of an overestimation under stable conditions. Data of RIDER (1954b) in experiments with oats, show an error of the same magnitude. Data of evapotranspiration in the Rottegatspolder (WERKCOMMISSIE VOOR VERDAMPINGSONDER-

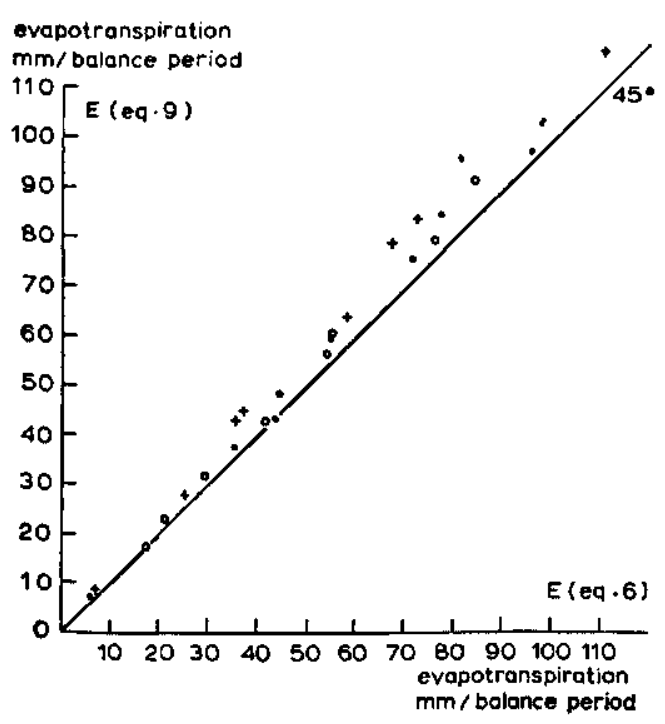

Fig. 7. The relation between the evapotranspiration calculated with equation (6) and with equation (9) for periods of approximately 30 days in the Rottegatspolder (WERKCOMMISSIE VOORVERDAMPINGSONDERZOEK, 1958-1960)

- summer wheat (1958); + flax (1959); - grass (1960)

zOEK, 1958-1960), presented in figure 7, calculated through with both formulae over periods of about a month, show a maximum deviation of $15 \%$. These data taken from literature show, that when calculating evapotranspiration with equation (6) 
the values have generally a deviation smaller than $15 \%$. Equation (9) offers possibilities for a more accurate calculation of evapotranspiration. Practical application is difficult, however, due to the uncertainties arising in exactly determining the value of $\beta$. A calculated first estimate of the roughness function based on equation (6) will therefore be used in the analysis of the evapotranspiration data measured with the lysimeters.

Neglecting the zero plane displacement when calculating the evaporation from a free water surface and the evapotranspiration from a surface covered with grass, assuming an air pressure of $76 \mathrm{~cm} \mathrm{Hg}$ and an air temperature of $20^{\circ} \mathrm{C}$, subject to the boundary conditions:

$$
\begin{array}{lll}
z_{2}=200 & u_{2}=u & e_{2}=e_{a} \\
z_{1}=0 & u_{1}=0 & e_{1}=e_{s}
\end{array}
$$

transforms equation (6) into:

$$
E=\frac{13.65}{\left(\ln \frac{200+z_{0}}{z_{0}}\right)^{2}} u\left(e_{s}-e_{a}\right)
$$

where $u$ is the wind velocity measured at 2 meter height in $\mathrm{m} \cdot \mathrm{sec}^{-1}, e_{s}$ and $e_{a}$ the vapour pressure in $\mathrm{mm} \mathrm{Hg}$ respectively at the surface and at $2 \mathrm{~m}$ height.

Data published by SUTTON (1953) of the roughness length of meadow grass at a wind velocity of $5 \mathrm{~m} \cdot \mathrm{sec}^{-1}$ at $2 \mathrm{~m}$ height are given in table 3 . The corresponding values of the calculated roughness function in equation (10) are also given.

Table 3. The roughness length and roughness function of meadow grass according to data of SUTTON (1953)

$\begin{array}{ccc}\text { Crop height } & \text { Roughness length } & \begin{array}{c}\text { Roughness function } \\ (\mathrm{cm})\end{array} \\ 1 & (\mathrm{~cm}) & \left(\left(\mathrm{mmH}_{2} \mathrm{O}\right) \text { day }^{-1} \mathrm{~m}^{-1} \mathrm{sec}(\mathrm{mmH})^{-1}\right) \\ 10 & 0.1 & 0.236 \\ 50 & 2.3 & 0.679 \\ & 9 & 1.38\end{array}$

Equation (10) is very similar to the empirical Dalton equation. This equation utilizes a relationship which considers the overall transfer process from surface to bulk air, and relates the corresponding transfer factor only to the prevailing wind velocity. The equation can be written as follows:

$$
E=f(\bar{u})\left(e_{s}-e_{a}\right)
$$

where $f(\bar{u})$ is an empirically derived function of wind velocity, commonly given in the form:

$$
f(\bar{u})=a(1+b \bar{u})
$$

or:

$$
f(\bar{u})=c \bar{u}
$$


where $\bar{u}$ is the time averaged wind velocity measured at standard height and $a, b$ and $c$ are constants to be determined experimentally.

The Dalton equation is particularly applied to calculate the evaporation from free water surfaces. Measurements of the water temperature at 1 or $2 \mathrm{~cm}$ below the surface are sufficiently accurate to determine the saturated vapour pressure at the surface. This method is in principle, with a modification of the constants, also applicable for other evaporating surfaces. Difficulties arise, however, in the determination of the vapour pressure at the evaporating surface of cropped soils. For this reason the Dalton equation has not been applied to cropped surfaces.

\section{Energy balance}

Evaporation is a change in state, demanding a supply of energy as latent heat of vaporization. The problem in the energy balance approach is to measure all other sources and sinks for energy, leaving evaporation as the only unknown. Neglecting the amount of energy used for photosynthesis and for the moment not considering the supply of advective energy, the energy balance can be written as follows:

$$
(1-r) H_{s h}-{ }^{n t} H_{l o}=L E+K+S+G
$$

where $H_{s h}$ is the global shortwave radiation, ${ }^{n t} H_{l o}$ the net longwave radiation, $L E$ the latent heat flux density of evaporation, $K$ the sensible heat flux density to the atmosphere, $S$ the sensible heat flux density in the soil, $G$ the storage of heat in the crop, $r$ the reflection coefficient of the surface and $L$ the heat of vaporization.

\subsection{Shortwave radiation}

The shortwave radiation can be measured with reasonable ease and accuracy using solarimeters. The number of places at which it is measured, however, is rather small. For practical purposes it is necessary therefore to fall back on an empirical relation of the form:

$$
H_{s h}=(a+b n / N) H_{a}
$$

where $H_{a}$ is the theoretical maximum incoming radiation if there was no atmosphere, the ratio $n / N$ the actual duration of bright sunshine as a fraction of the maximum possible duration for a cloudless sky, while $a$ and $b$ are empirically determined constants depending on the place on earth.

This relation can according to DE VRIES (1955) be changed under conditions prevailing in the Netherlands into:

$$
H_{s h}=\{\alpha+(1-\alpha) n / N\}^{\max } H_{s h}
$$

where ${ }^{\max } H_{s h}$ is the maximum amount of shortwave radiation reaching the earth 
surface on clear days. The constant $\alpha$ varies from 0.25 to 0.34 depending on the time of the year. De Vries proposed to give $\alpha$ for practical use a mean value of 0.29 . The accuracy reached in calculating incoming shortwave radiation during short periods from this empirical relation in comparison to the measured data is not high, as appears from data given by RiJTEma (1959) and presented in figure 8. The variation in the data indicates that equation (12a) is not to be used for the calculation of shortwave radiation over short periods. DEACON a.o. (1958) comparing measured and calculated data of shortwave radiation, give a variation of $15 \%$. This variation can be partly explained by instrumental errors of the sunshine recorder. The recorder is not registrating when thin clouds are present, nor in conditions of low radiation intensity on clear days just after sunrise and before sunset. The amount of shortwave radiation reaching the earth surface is strongly dependent on the type of clouds and the time of the day that cloudiness is present. It is well known that on days with a partly clouded

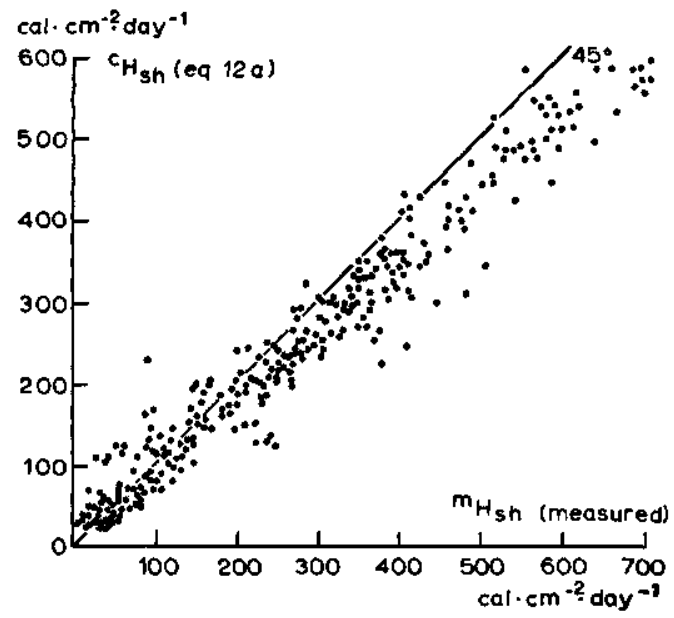

Fig. 8. Relation between measured incoming shortwave radiation $\left({ }^{m} H_{s k}\right)$ and data calculated with equation ( $12 a)\left({ }^{c} H_{m k}\right)$ in 1957 at Wageningen (RIJTEM, 1959)

sky, when the sun is visible through a gap between the clouds, reflection from their sides can in effect add to the intensity and can increase the solar radiation that is received.

It is therefore preferable, if possible, to use measured data of shortwave radiation instead of calculated ones. In this study measured data have been used.

\subsection{Reflection coefficient}

Because the reflection coefficient depends on the angle of incidence, which in particular for the direct radiation varies with latitude, with season and time of day, as well as with the type of surface (ASHBURN and WELDON, 1956), the amount of total incident radiation that is reflected by a given surface is by no means constant. Mainly, only daily mean values of the reflection coefficients of various land surfaces 
are known. Reflection coefficients, concerning a grass crop, as reviewed from literature by SCHOLTE UBING (1959) cover a range from 0.16 to 0.33 , depending also on crop height and wetness of the surface. Measurements concerning the mean reflection from grass, with a crop height from 8 to $30 \mathrm{~cm}$ performed at Wageningen (SCHOLTE UBING, 1959) gave a value from 0.19 to 0.21 for the coefficient. MoNTEITH (1959), measuring the mean reflection from various crops, short grass included, with a full cover of the soil, presents data varying from 0.24 to 0.26 .

WARTENA and BORGHORST (1961), measuring the reflection coefficient in shallow evaporation pans, present a mean value of 0.08 , also due to the reflection from the bottom of the pan. The pan used by these authors was filled with clear water and had a depth of $17.5 \mathrm{~cm}$. The $25 \mathrm{~cm}$ deep pans used in the present study were filled with groundwater taken from a shallow well. The water was not entirely clear, so the bottom of the pans was hardly visible. The influence of the bottom on the reflection coefficient is under these conditions very small. For this reason the, for the mean reflection coefficient of a free water surface, generally accepted value of 0.05 will be used in the calculations of evaporation.

In the analysis of the evapotranspiration data from the lysimeters the mean reflection coefficient of a crop is taken into account as an unknown constant because of the variation in the data presented in literature and in regard to the importance of this factor in the energy balance approach.

\subsection{Net longwave radiation}

The magnitude of the net longwave radiation depends on surface temperature, air temperature, atmospheric water vapour and cloudiness. Both the height of the effective radiating surface of a crop and the radiating surface temperature are generally difficult to determine. Equality of surface temperature and air temperature at $2 \mathrm{~m}$ height is usually assumed when calculating net longwave radiation for periods of more than one day. This proposition is not allowed when calculating short term net longwave radiation, because then important differences in surface and air temperature can exist (ROBInson, 1950; MONTEITH and SzEICZ, 1962). The highest surface temperatures occur generally in a short, open crop, which decreases strongly the movement of air near the surface (Broadbent 1950). Data reported by MoNTEITH and Szeicz (1962), given in table 4, indicate that the mean temperature during 24 hours, of various cropped surfaces and air temperature measured in the screen do not differ very much.

A full discussion, concerning the existing empirical relations used in the calculation of net longwave radiation, was given by ScHOLTE UBING (1959). The suitability of the different relations depends strongly on the atmospheric conditions. Some of these relations gave the best results under conditions of heavy cloudiness, while others gave the best fit under conditions of a clear sky. The relation originating from Penman (1948) was used in calculating net longwave radiation in this study, with the aid of tables published by Wesseling (1960). 
Table 4. Maximum, minimum and mean temperature in ${ }^{\circ} \mathrm{C}$ of air and of various surfaces on clear days, according to MONTEITH and SzEICZ (1962)

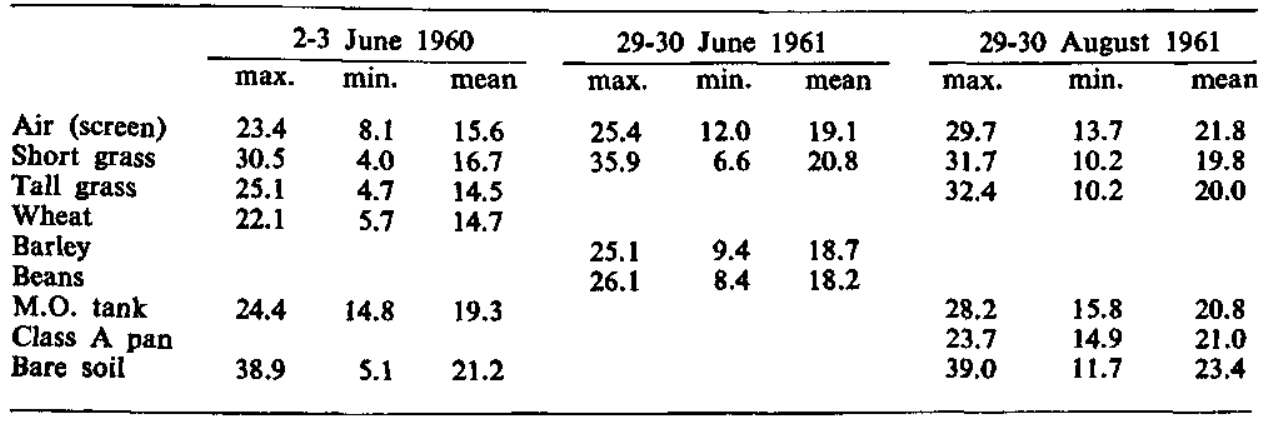

Net longwave radiation is calculated, assuming equality of air- and surface temperature, with the following equation:

$$
{ }^{n t} H_{\text {lo }}=\sigma\left(273+T_{0}\right)^{4}\left(0.56-0.092 \sqrt{ } e_{a}\right)(0.10+0.90 n / N)
$$

Where $\sigma$ is the constant of Boltzman $\left(118 \cdot 10^{-9} \mathrm{cal} \cdot \mathrm{cm}^{-2} \cdot\right.$ day $\left.^{-1} \cdot{ }^{\circ} \mathrm{K}^{-4}\right), T_{a}$ the air temperature in ${ }^{\circ} \mathrm{C}, e_{a}$ the vapour pressure in $\mathrm{mm} \mathrm{Hg}$ and $n / N$ the relative duration of bright sunshine.

A deviation of $10 \%$ between calculated and measured net longwave radiation can exist under clear sky conditions due to atmospheric irregularities (ROBINSON, 1950; Goss and BRoOKs, 1956). The deviation can increase considerably due to cloudiness. Net longwave radiation depends strongly on the type of clouds. Moreover a good correlation between cloudiness during the night and the relative duration of bright sunshine during daytime hours is necessary. Using equation (13), considerable differences may be expected over short periods between calculated and real net longwave radiation (SCHOLTE UBING, 1959; ABDEL-AzIZ a.o., 1964).

\subsection{Sharing of net radiation}

Net radiation on a horizontal plane surface can be calculated from the following expression:

$$
H_{n t}=(1-r) H_{s h}-{ }^{n t} H_{t_{0}}
$$

The main problem in the approach of the energy balance is the division of $H_{n t}$ between the other terms expending energy. The height and the density of the crop and the water supply to the crop have influence on the distribution of energy used for evapotranspiration, for sensible heat transfer to the air and for the transfer of heat to the soil. The storage of heat in the crop is generally small and may be neglected over periods longer than one day.

The amount of heat transfer to or from the soil is only a small component of the balance and is therefore often neglected. During short periods, however, this short 
term transfer may become more important. MONTEITH (1958), measuring the storage of heat in the soil beneath various crops (wheat, potatoes and grass) concludes that the neglect of this term in balance periods of some days, does not lead to serious errors. This storage term amounts to $10 \%$ of the net radiation during some periods of clear weather. TANNER and Pelton (1960) report a storage of heat in the soil beneath just moved alfalfa of $9 \%$ of the net radiation. The absolute mean ratio $|S| H_{n t} \mid$ was 0.05 during the period from July to September, while the arithmic mean amounts to -0.03 .
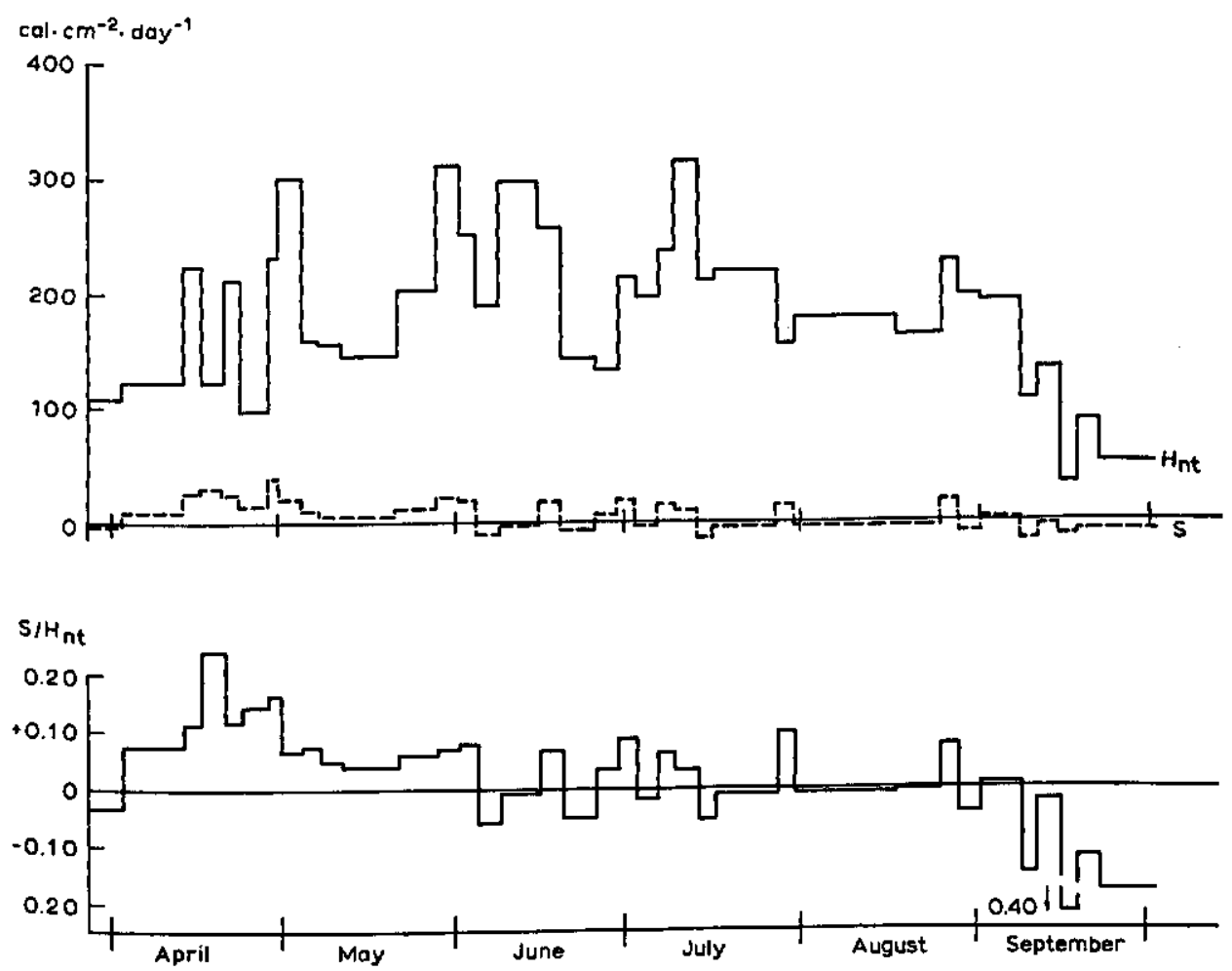

Fig. 9. The course of $H_{n t}$ ), $S(---)$ as well as $S / H_{n t}$ in 1958 calculated for loamy sand in a lysimeter with the groundwater table at $125 \mathrm{~cm}$ below the surface

The storage of heat in the lysimeters was calculated from changes in the temperature profile of the soil, combined with estimates of the heat capacity of the soil, using a simple formula, varying mainly with soil moisture content. The additivity of specific heat leads to an additivity in volumetric heat capacity in those cases when volume changes due to moisture changes can be ignored. Under these conditions the volumetric heat capacity of the soil can be calculated with the following expression (see also DE VRIES, 1953):

$$
C_{s}=0.46 x_{m}+0.60 x_{o}+x_{w}
$$


Where $C_{s}$ is the volumetric heat capacity of the soil in cal $\cdot \mathrm{cm}^{-3} \cdot\left({ }^{\circ} \mathrm{C}\right)^{-1}$ and $x_{m}$, $x_{0}$ and $x_{w}$ are the volume fractions of mineral and organic material, and water respectively. The soil moisture content of the various layers was measured with the aid of nylon units.

The distribution of $H_{m}$ and $S$ in a lysimeter filled with loamy sand during the growing season of 1958 is presented in figure 9, as well as the ratio $S / H_{n t}$. The heat storage in spring and in autumn seems to be somewhat larger than should appear from the data to be found in literature. This is mainly due to the open connection of the walls of the lysimeters used in the present study, via the observation cellar, with the outside air, which causes an additional flux of heat into and out of the deep layers of the soil. Soil temperatures measured at a depth of $1 \mathrm{~m}$ in the loamy sand are presented in figure 10. Data of soil temperatures, published by the DEPARTMENT of Physics and Meteorulogy of the Agricultural UNIVERSITY (1958), measured in the field at a depth of $1 \mathrm{~m}$ are also given in this figure. The data measured in the lysimeter show more variation than those measured in the field. The general trend of the heat storage is, bowever, of the same order of magnitude as that of the data given in literature.

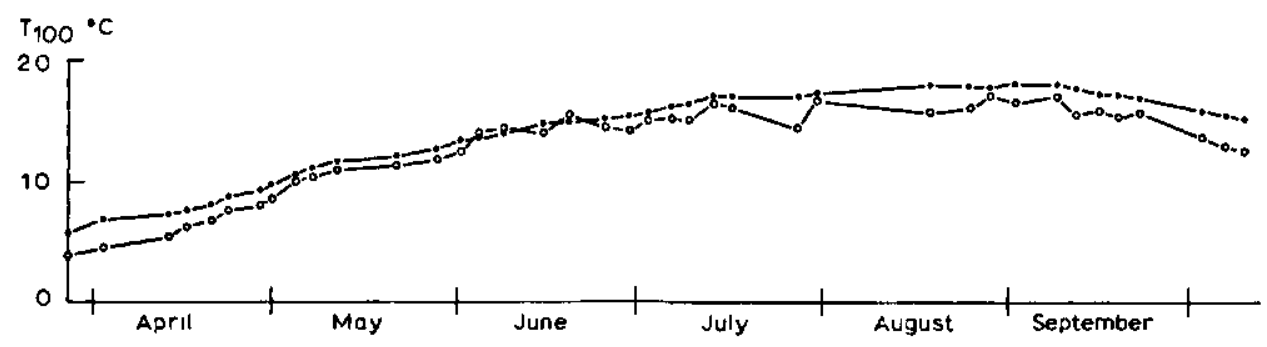

Fig. 10. The variation in soil temperature at $100 \mathrm{~cm}$ below the surface in 1958

- -0 loamy sand in a lysimeter

$\bullet-\bullet$ sand in natural conditions (Department of Physics AND Metrorology, 1958)

The errors resulting from the neglect of heat storage in the soil when calculating potential evapotranspiration, depend on the existing wind velocity and humidity of the air. MONTEITH (1958) reports, under conditions of clear summer weather in England that a neglect of a storage in the soil of $10 \%$ of the net radiation gives an error in the order of $7 \%$ in the calculated potential evapotranspiration.

The net heat flux density into the soil reaches its smallest value during the summer months, when the soil temperature comes near its maximum value. The largest errors in the calculated evapotranspiration arise, neglecting heat storage in the soil, in spring with increasing soil temperature and in autumn when a rather rapid cooling occurs.

Mostly, the storage of heat in the soil is neglected, when calculating potential evapotranspiration for periods of 10 days or longer. Net radiation has to be divided in that case only between evapotranspiration and sensible heat transfer to the 
atmosphere. Both terms can be separated using the Bowen ratio, which requires the time averaged measurements of the vertical temperature and vapour pressure gradients. The Bowen ratio can be written as follows:

$$
\beta=\frac{K}{L E}=\gamma\left(\frac{K_{H}}{K_{V}}\right)\left(\frac{T_{s}-T_{a}}{e_{s}-e_{a}}\right)
$$

where $\gamma$ is the psychrometer constant $\left(0.485 \mathrm{~mm} \mathrm{Hg} \cdot\left({ }^{\circ} \mathrm{C}^{-1}\right)\right.$ to keep consistent units, $T_{s}$ and $T_{a}$ are respectively the surface and air temperature, $e_{s}$ and $e_{a}$ the vapour pressure respectively at the surface and in the air and $K_{H}$ and $K_{V}$ the turbulent transfer factors of heat and water vapour.

On the identity of the turbulent transfer factors $K_{H}$ and $K_{V}$ some discussion exists in literature. The identity of both factors can, according to PASQuILL (1949a), only be shown under stable and neutral atmospheric conditions. It appears from these data that $K_{H}$ may exceed $K_{V}$ considerably in an unstable atmosphere. SwinbanK (1955) has shown that the ratio $K_{H} / K_{V}$ increases with increasing atmospheric instability. The scatter in these data is very large, however.

TAYLOR (1960), presenting a further analysis of the data given by SwINBANK (1955) and RiDER (1954a), concludes that both factors are identical. According to this author, some uncertainty only remains under very unstable atmospheric conditions. Rider and RoBINSON (1951) and SUOMI and TANNER (1958), when measuring the energy balance could not show a variation in the ratio $K_{H} / K_{V}$ under unstable atmospheric conditions. The method used by these authors is, however, generally not very sensitive to a variation in this ratio. Investigations under various conditions of atmospheric stability reported by CRAWFORD (1965) also show strong indications concerning the identity of both factors.

Identity of both transfer factors has been assumed, based on the considerations given before, in the analysis of the lysimeter data.

Combining the following equations:

$$
L E+K=H_{n t}-S
$$

and

$$
K=\beta L E
$$

gives the expression for the energy used for evapotranspiration:

$$
L E=\frac{H_{n t}-S}{1+\beta}
$$

As long as $\beta$ is not less (more negative) than -0.5 , an error in $E$ is significantly less than an error in $\beta$. The fact that the equation becomes indeterminate when $\beta$ approaches -1 seems at a first glance to be a serious failing. However, $\beta$ approaches -1 only during relatively unimportant periods when the heat exchange is low, for example at sunrise, sunset and occasionally during the night. 
The success of the energy balance estimate depends on the measurements of the surface temperature. In the aerodynamic equation the surface vapour pressure is needed. Both the vapour pressure and temperature at the surface of free water can be determined with reasonable accuracy measuring the temperature close below the surface. It is difficult, however, to measure these data at the evaporating surface of a crop.

Penman (1948) and McIlroy (Slatyer and McIlroy, 1961) evolved equations consisting of a combination of the energy balance and the empirical Dalton equation. These combination methods have the advantage that the calculated evapotranspiration becomes less sensitive to errors in the experimentally derived wind function in the Dalton equation.

\subsection{Method of Penman}

PENMAN (1948, 1956) assuming identity of heat and vapour transfer factors, neglecting storage of heat below the evaporating surface, combined the two simultaneous equations:

$$
L E=L f(u)\left(e_{s}-e_{a}\right)
$$

and

$$
H_{n t}=L E+K
$$

in order to evolve an equation for the calculation of evaporation from a free water surface.

Substituting (10d) in the Bowen ratio (16) yields the following equation for the sensible heat flux to the atmosphere:

$$
K=L \gamma f(u)\left(T_{s}-T_{a}\right)
$$

Equation (18), introducing a new variable $\Delta=\partial \varepsilon / \partial T$, the slope of the temperaturevapour pressure curve and assuming a saturated vapour pressure at the surface, can be transformed into:

$$
K=\frac{L \gamma}{\Delta} f(u)\left(\varepsilon_{s}-\varepsilon_{a}\right)
$$

where $\varepsilon_{s}$ and $\varepsilon_{a}$ are respectively the saturated vapour pressure at the surface and in the air at temperature $T_{a}$. The value of $\Delta$ can be approximated by the slope of the vapour pressure curve at air temperature, if the differences between the mean values of air Mand surface temperature are not too large.

Rearranging equation (18a) gives the following expression:

$$
K=\frac{L \gamma}{\Delta} f(u)\left(\varepsilon_{s}-e_{a}\right)-\frac{L \gamma}{\Delta} f(u)\left(\varepsilon_{a}-e_{a}\right)
$$


Substituting equation (10d) gives:

$$
K=\frac{L \gamma}{\Delta} E-\frac{L \gamma}{\Delta} E_{a}
$$

where $E_{a}$ in the equation (Penman, 1956) is given by:

$$
0.35\left(0.50+0.54 u_{200}\right)\left(\varepsilon_{a}-e_{a}\right)
$$

Combination of (1lb) and (18c) shows the well-known equation presented by Penman for the calculation of evaporation from a free water surface:

$$
E_{o}=\frac{\Delta H_{n} / L+\gamma E_{a}}{\Delta+\gamma}
$$

In order to calculate the potential evapotranspiration from a crop Penman introduced a reduction factor by which the calculated evaporation from a free water surface is to be multiplied. A full discussion on the reduction factor presented by Penman is given in Chapter IV.

\subsection{Method of Mcllroy}

Mcllroy (SLATYER and MCILROY, 1961) evolving a combination method, used the following basic equations:

$$
K=h\left(T_{s}-T_{z}\right)
$$

and

$$
L E=\frac{h}{\gamma}\left(e_{s}-e_{z}\right)
$$

where $h$ is a wind velocity dependent overall transfer factor between zero level and height $z$ of the Dalton type.

Using the psychrometric equation for fully ventilated thermometers:

$$
e=\varepsilon_{T_{w}}-\gamma\left(T-T_{w}\right)=\varepsilon_{T_{w}}-\gamma D
$$

where $\varepsilon_{T_{w}}$ is the saturated vapour pressure at wet bulb temperature $T_{w}$ and $D$ is the wet bulb depression $\left(T-T_{w}\right)$, the vapour pressure difference can be given by the expresssion:

$$
e_{s}-e_{z}=\left(\varepsilon_{T_{w z}}-\varepsilon_{T_{w z}}\right)-\gamma\left(D_{s}-D_{z}\right)
$$

Introducing the slope $s$ of the vapour pressure curve at the mean wet bulb temperature:

$$
s=\left[\frac{\partial \varepsilon_{T_{w}}}{\partial T_{w}}\right]_{T_{w a}}
$$


where $T_{w a}$ is $\left(T_{w s}+T_{w z}\right) / 2$ yields the following equation:

$$
e_{s}-e_{z}=s\left(T_{w s}-T_{w z}\right)-\gamma\left(D_{s}-D_{2}\right)
$$

With equation (23a) the expression (21) for evapotranspiration becomes:

$$
L E=\frac{h s}{\gamma}\left(T_{w s}-T_{w z}\right)-h\left(D_{s}-D_{z}\right)
$$

Expressing equation (20) in the same terms gives:

$$
K=h\left(T_{w s}-T_{w z}\right)+h\left(D_{s}-D_{z}\right)
$$

Substituting (20a) and (21a) in equation (11a) yields:

$$
H_{n t}-S=K+L E=h\left(T_{w s}-T_{w z}\right)\left(1+\frac{s}{\gamma}\right)
$$

In this expression $h\left(T_{w s}-T_{w z}\right)$ can be eliminated with equation (21a) giving the equation for evapotranspiration developed by McIlroy:

$$
E=\left(\frac{s}{s+\gamma}\right)\left(\frac{H_{n t}-S}{L}\right)+\frac{h}{L}\left(D_{z}-D_{s}\right)
$$

\subsection{Discussion of the combined methods}

It is mainly the neglect of the heat storage below the evaporating surface, as well as the neglect of the vapour pressure deficit at nonsaturated evaporating surfaces, which gives the equation proposed by Penman a limited applicability in calculating the evapotranspiration from a crop. Moreover fixed constants have been assumed in the function of wind velocity, irrespective of the type of surface and of the surface roughness. Further an empirically determined reduction factor has to be applied in order to compute evapotranspiration from the calculated evaporation from a free water surface. The difference in reflection of a crop and a free water surface is not taken into account in this type of calculations.

When using the equation presented by Mcliroy in particular all uncertainties in $h$ and $D_{s}$ have to be solved. The determination of $h$ and $s$, the latter being principally not similar to the corresponding factor $\Delta$ in the Penman equation, requires an iterative procedure with the aid of equation (11c). The necessity of this procedure, offers particularly in the case of crops with a highly varying surface roughness during the growing season, a predominant objection.

In the analysis of the evapotranspiration data from the lysimeters in this study a combined method is used, originating from the basic principles presented by Penman, taking into account the reflection, the roughness and the saturation deficit of the evaporating surface. A full discussion concerning the vapour pressure deficit at the surface is given in Chapter IV. 
4. Comparison of calculated evaporation from a free water surface with measured pan evaporation

Because of the simplicity of construction and operation, standardized evaporation pans have become widely used for the measurements of the evaporation. In reality they measure nothing more than a strictly local value of the evaporation from a pan of special size, shape and colour in a special type of surroundings. The measured evaporation data depend considerably on the construction and the exposure of the pan. A critical review concerning the suitability of pan data in the calculation of short period evapotranspiration, was given by VAN WIJK and DE WILDE (1962). These authors conclude that it is not possible to use fixed pan coefficients for crops under different conditions of climate and exposure.

The data are generally higher for above ground pans than for sunken ones (RAMDAs 1957). KOHLER a.o. (1955) and in particular WARTENA (1959) have made a full study concerning the energy balance of the U.S. Weather Bureau Class A pan, exposed above the ground. Wartena concludes concerning this type of exposure, that an evaporation pan can be used only as a simple indicator for the determination of the amount of water that has to be supplied into an irrigation area. He concludes that it is not possible to give panfactors for evaporating crops, which satisfy under all conditions.

Due to the absorption of radiation through the pan wall, as well as to a transfer of sensible heat between the air and the pan wall, the above ground pan receives an extra amount of energy, which results in a higher value of evaporation, than is calculated with the Penman method. Data, given by RYHINER and RIJTEMa (1963), showing the relation between measured and calculated evaporation are presented in

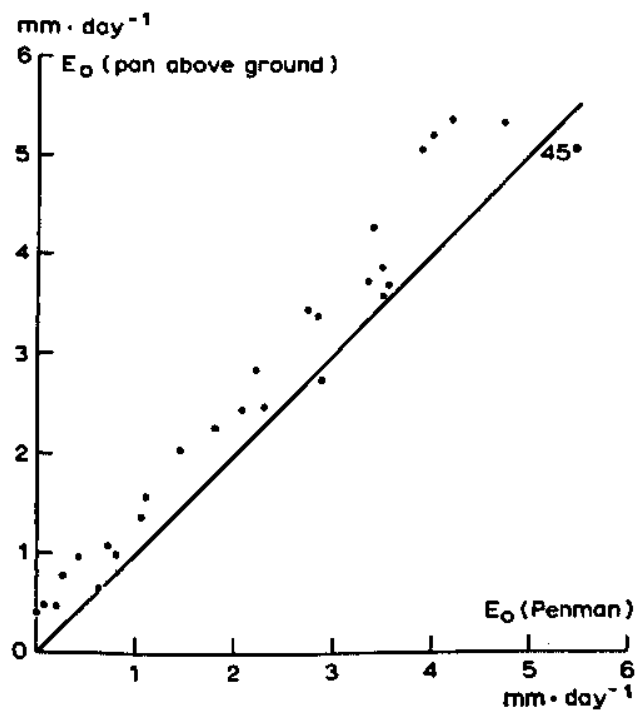

Fig. 11. Relation between the evaporation calculated with the Penman equation $\left(E_{0}\right)$ and data measured with a pan above ground according to RYHINER and RUTEMA (1963) 
figure 11. HounAM (1958) comparing measured and calculated evaporation data, indicates that the pan coefficient varies both with season and climate.

At a first glance it seems that more realistic data of evaporation are measured with sunken pans, because of the fact that the wall and the bottom of the pan are not influenced by radiation and heat transfer from the air. A number of other factors, however, affect the measured evaporation from sunken pans. The surface roughness of the immediate surroundings has a predominant effect, influencing the flow of air above a small pan. Investigations reported by BONYTHON (1950) show that a drop of $5 \mathrm{~cm}$ in the height of the water level reduces measured evaporation with $15 \%$. Moreover an existing temperature gradient between pan wall and surrounding soil can affect measured evaporation due to heat transfer between soil and pan. This fact results in a possible influence of preceding weather on the evaporation data. The direct surroundings of the pan must have a good water supply to ensure a potential evapotranspiration from the environment in order to prevent effects of local advection. Investigations, reported by RAMDAS (1957) seem to indicate that local advection has no influence when the surroundings have a good water supply to a distance of $6 \mathrm{~m}$.

The following requirements to the exposure of sunken pans, can now be given:

a. the absorption of radiation by the walls will have to be reduced to a minimum value,

b. the exchange of heat between pan and soil must be limited,

c. the surface roughness of the direct environment must be kept as small and constant as possible,

b. the surroundings of the pan must have a good water supply to ensure potential evapotranspiration from the direct environment,

e. the water in the pan has to be kept at a constant level,

f. the storage of heat in the pan will have to be small, which limits the depth of the pan,

g. the wind direction must not affect evaporation, which requires circularly shaped pans.

A good agreement exists between measured evaporation from sunken pans and the data calculated from climatological observations, when the proposed requirements are fulfilled as good as possible (BonYthon, 1950; StanHLL, 1958; RIJTEMA, 1959; Fleming, 1964; MCILroY and ANGUS, 1964). The evaporation calculated with the equation presented by Penman is generally somewhat higher than the data measured with sunken pans. This was also shown by MAKKINK (1957), calculating evaporation on a daily base. The main source causing the systematic deviation seems to be the wind function that is used in the Penman equation. The constants in this function were determined from a combination of Penman's own experiments and the results of the Lake Heffner study (see PENMan 1956). Because of both the size and exposure of the pan used in the present study, as well as the influence of the surroundings, the effect of the wind velocity may have been smaller than in the conditions under which 
the experiments reported by Penman were performed. A back solution was applied with the observed evaporation data in 1957 and 1958 averaged over 10 days periods, in order to obtain a correction for the effect of wind velocity on pan evaporation, using the expression:

$$
E_{p a n}-\frac{\Delta H_{n t} / L}{\Delta+\gamma}=c \frac{\gamma u\left(\varepsilon_{a}-e_{a}\right)}{\Delta+\gamma}
$$

It appeared from this back solution that a value of $c$ equal to 0.182 gave the best fit. A comparison between the measured pan evaporation and the calculated evaporation from a free water surface, using the modified wind function, is presented in figure 12.

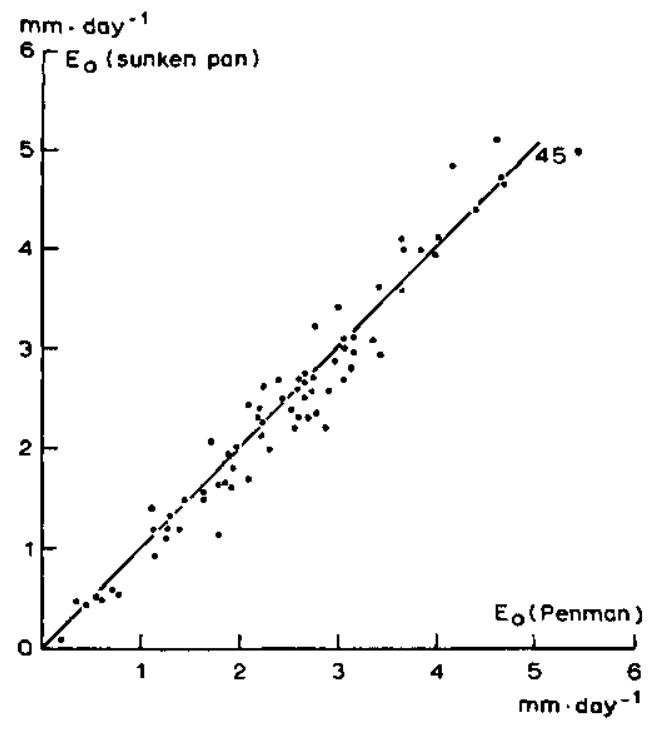

Fig. 12. Relation between the evaporation calculated after Penman with a modified wind function and data measured with sunken pans. Mean values for periods of 10 days from April to November in 1960, 1961, and 1962

The data give mean values for periods of 10 days, measured from April 1 to November 1 during the years 1960,1961 and 1962 . The remaining variation has to be accepted, because of the uncertainties in the calculated data, as well as in the measured ones, particularly when heavy rains were present.

\section{Influence of advection on evapotranspiration}

Relatively little is known about the effect of local advection on evapotranspiration. A supply of advective energy will generally be small over an extensive homogeneous surface. A large influence of advection exists under conditions of strong variation in water supply, when for example air flows from a dry area into an irrigated one (oasis effect). The advective term in the energy balance equation is neglected under many practical conditions because of the small values of the horizontal gradients. 
The neglect of advection may cause a considerable error when using lysimeters or small fields in evapotranspiration studies.

Two processes have to be taken into account in relation to local advection. When, besides vertical vapour pressure gradients, horizontal gradients exist, there is also a horizontal transport of vapour, which increases the evapotranspiration. Moreover, a supply of warm air above the evaporating surface increases by means of sensible heat transfer the energy available for evapotranspiration (TANNER and LEMON, 1961; RIDER a.o. 1963). DE VRIES (1962) proposed some theoretical considerations in order to calculate evapotranspiration in an irrigated area. HALSTEAD and CoveY (1957) give also indications for the calculation of the oasis effect. The possibilities for calculation are highly depending on the size of the oasis. For small surfaces as lysimeters, the required measurements of the horizontal gradients in temperature and vapour pressure cannot be made.

Comparisons, performed at Davis (U.S.A.) and Aspendale (Australia) (SLATYER and MCILroY, 1961; MCILroY and ANGUS, 1964) between evapotranspiration calculated with combined methods, and measured data from lysimeters show good agreement even on days with strong advection, if the direct surroundings were well supplied with water. The combined methods seem to satisfy under conditions of large-scale advection. The effects of small-scale advection, however, are more difficult to estimate. These effects seem to be eliminated over short distances, as was indicated by RAmDAS (1957), using evaporation pans. Data concerning the effect of local advection on the evapotranspiration rate from Ladino Clover, measured with small lysimeters at different distances downwind from a dry area, given by MILLAR (1964), are presented in table 5. These data also indicate that the effect of small-scale

Table 5. Distance downwind and evapotranspiration rate from Ladino Clover, according to MiLLAR (1964)

$\begin{array}{lllll}\text { Distance (meters) } & 0.14 & 1.67 & 4.72 & 13.87 \\ \text { Evapotranspiration } & 78.4 & 74.0 & 70.2 & 70.3 \\ \left(10^{-2} \text { mm hour }^{-1}\right) & & & & \end{array}$

advection is eliminated over a short distance. Similar results were obtained by McIlroY and ANGUS (1964). The possible effects of local advection have to be taken into account when comparing calculated evapotranspiration and measured data from lysimeter investigations, if the surroundings have a shortness of water. Experiments with Blue Grass, reported by DRINKWATER and JANES (1957) show a decrease of $23.2 \%$ in evapotranspiration from frequently irrigated lysimeters when the direct surroundings were as well supplied with water. LEMON a.o. (1957) showed that the short term evapotranspiration from cotton can exceed available net radiation by a factor 2.5, due to the oasis effect. According to TANNER (1960) it is not possible using the energy balance to calculate evapotranspiration from alfalfa succesfully, when the local advection highly affects the measured data. 
The influence of local advection was not considered in the comparison between calculated evaporation from a free water surface and measured pan evaporation. An eventual occurrence of short periods with lack of water in the environment could not be proved with any confidence during the majority of the years of observation.

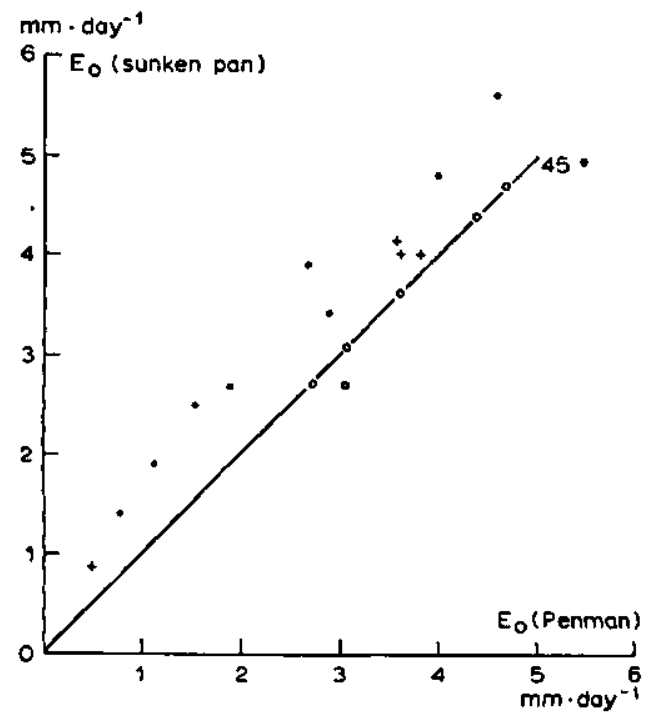

Fig. 13. Relation between the evaporation calculated with the modified Penman equation and data measured with sunken pans. Mean values for periods of 10 days in 1959

- environment dry

0 environment wet

+ environment during a part of the period wet

An exception must be made only for the dry summer of 1959 , when during periods in which the surroundings had a shortness of water, the measured pan evaporation exceeded considerably the calculated evaporation from a free water surface. The results of this comparison are presented in figure 13. The evapotranspiration from lysimeters, with a water supply deviating from the surroundings is increased in these periods due to the effect of local advection. A correction has to be applied under these conditions, in order to take this term into account. An approach to this effect in the data used in this study is discussed in Chapter VI.

\section{Summary}

A general discussion on the meteorological aspects determining the evapotranspiration from crops is presented.

The transport of water vapour from the evaporating surface to bulk air is mainly determined by the vapour pressure gradient, the turbulence of the moving air and the roughness of the evaporating surface. The vertical distribution of wind velocity under neutral atmospheric conditions can be given by a logarithmic function of the height above surface. In other atmospheric stratifications a power function of height gives better results. Difficulties arise, however, in determining with any confidence the exponent in the function. The error introduced, measuring close to the surface and 
using the logarithmic function, in the calculated evapotranspiration is in the order of 10 to $15 \%$. It appears that the roughness of the evaporating surface depends on the development of the crop, as well as on wind velocity.

Evapotranspiration can also be calculated from the energy balance. The accuracy reached, when using empirical relations in the calculation of net radiation, is not high over short periods. An error of 10 to $20 \%$ in net radiation will have to be expected over periods of a few days.

The storage of heat in the soil during periods of some days under field conditions amounts to a maximum value of $10 \%$ of net radiation. The heat transfer into the soil in the lysimeters appears to be somewhat higher in spring and in autumn, due to the exposure of the containers.

Dividing of the available energy between evapotranspiration and sensible heat transfer to the atmosphere is performed, with the use of the Bowen ratio, which requires the time averaged measurements of the vertical gradients of temperature and vapour pressure. In order to prevent the measurements of these gradients, combined methods have been introduced. It is necessary to take into account the properties of the evaporating surface when using such a method for the calculation of evapotranspiration from crops.

Comparison of measured pan evaporation and calculated evaporation from a free water surface did show a good agreement when sunken pans were used. The above ground pans give, related to their exposure, systematically too high values of evaporation. A number of requirements for the exposure of sunken pans was given.

There is some evidence from data reported in literature, that the combined methods also satisfy under conditions of strong large-scale advection. Small-scale local advection can highly affect evapotranspiration, when using lysimeters in a study on this subject. These small-scale effects are difficult to estimate. Some indications are present in literature that these effects are eliminated over short distances. A systematic influence of small-scale advection during the experiments reported in this study, could only be proved during the very dry summer of 1959. 


\section{Plant physiological aspects of evapotranspiration}

\section{Water transport in plants}

Absorption of water by plants is controlled primarily by transpiration. It is usually considered as a result of vaporization of water from the mesophyll cells in the leaves, tending to cause a decrease in turgor pressure and therefore a fall in cell water potential. The thus established potential gradient from the mesophyll cells to the leaf xylem traces, is implicitly transmitted through the intact water columns of the plant xylem across the root cortex to the soil. Water then moves from the soil surrounding the roots through the plant to the atmosphere, due to the potential gradient.

The uptake and flow of water through the plant is determined by a number of physical and physiological processes. The physical processes concern diffusion and possibly mass-flow through the root cells, mass-flow through the xylem vessels, diffusion and mass-flow through the leaf tissue and diffusion of water vapour from the intercellular cavities to the air outside. The physiological processes concern the variation in permeability of the root cells, the possible existence of a complex absorption mechanism and the control of siomatal aperture.

Root pressure determines the rate of moisture uptake under conditions of optimum water supply and a very low transpiration rate, because water is in that case taken up by means of osmotic diffusion from the soil due to the osmotic pressure in the xylem vessels (ARISZ a.o., 1951). A complex absorption mechanism in relation with water uptake has, according to KRAMER (1941), no predominant position because of the rapid reversibility of the direction of flow. It appears from a review of literature, presented by KRAMER (1945), that the root pressure of different crops is in the order of 0.5 to 2 atmosphere. An uptake of water is not possible by root systems of detopped plants when the soil moisture suction exceeds the root pressure. Complete plants, however, can still withdraw water from the soil when the soil suction amounts from 10 to 15 atmosphere. The amount of liquid secreted by detopped plants due to root pressure, is less than $5 \%$ of the amount of water used by the complete plants under conditions of high transpiration (KRAMER, 1939; WARNE, 1942). It appeared that under conditions of high transpiration a suction was present in the xylem vessels.

Water flow in plants through the various tissues, is determined by the existing potential gradients and transport resistances in the flow path. The total resistance for liquid flow in the plant is mainly determined by the largest resistance in the various parts of the transport path, when such a resistance considerably exceeds the other ones. Various investigations (BREWIG, 1937; KRAMER, 1938; WARNE, 1942; BROUWER, 
1954) show fairly conclusive that the flow resistance in the xylem vessels is relatively small. The main resistances in the plant are present when the transport of water goes from cell to cell, so in the leaf tissue and in the root cells.

\subsection{Resistance in the leaf tissue}

Two flow paths are possible when the water is transported from cell to cell. The flow can go through the cells, in which case the cell wall and the protoplasm act as media of resistance, as well as through the micropores in the cell wall. Generally both types of flow are present at the same time. The main transport, however, is along the flow path with the smallest resistance when a large difference in resistance exists. Levitr (1956) concludes on theoretical considerations that the flow in the leaf tissue cannot be explained by osmotic diffusion from cell to cell, but that a flow through the micropores has to be accepted as the main flow path. Investigations by CARR and GAFF (1961) show that the water in the cell walls of the leaf tissue is the main fraction of the total moisture present in the leaf. Experiments reported by WEATHERLY (1963) show that the resistance for osmotic diffusion through the cells is approximately 50 to 60 times the resistance for mass-flow through the micropores in the cell wall. LEvitT (1956) also concludes that the transport resistance in the cell walls is relatively small. The rapid restoration of wilted leaves by immersion in water (KRAMER 1938) also gives an indication of low transport resistances there.

\subsection{Resistance in the root cells}

Since the transport of water in the leaf cells is mainly located in the cell walls, such a flow path can generally be expected to exist in other parenchymatic tissues, and in particular in the root cells. The major resistance, however, seems to be present in the endodermis (ARISZ a.o., 1951). The flow of water through the cell walls of the endodermis is prevented by the Casparian strips, which locate the transport at this place through the living cells. MeEs and WeATHERLY (1957) show that about $75 \%$ of the flow is through the cells and only $25 \%$ of the transport occurs as mass-flow through the cell walls. The root is the only location where the transport of water is determined by the living cells, which means that at this place the resistance depends on metabolism. BROUWER (1954) and VAADIA a.o. (1961) also conclude that, when the root surface is abundantly supplied with water the major resistance to water uptake by the plants is in the root cells. Since the water transport in the root is mainly determined by the living cells, factors as soil temperature and aeration may affect the flow resistance.

Soil temperature affects the uptake of water by the roots in several ways. The viscosity of water increases with decreasing temperature. The viscosity of the protoplasm is also affected by temperature, causing a reduction in permeability of the living 
cells with decreasing soil temperature. Moreover, respiration is dependent on temperature, which also may affect the permeability of the root cells at low temperatures. When a constant potential gradient between root surface and xylem vessels is present, a reduction in flow will have to be expected with decreasing temperature. A reduction in transpiration, due to low soil temperatures has been observed by ABD EL RAHMAN a.o. (1959), Tew a.o. (1963) and EfrRLer (1963). The effects of low soil temperature on evapotranspiration vary widely for different crops, however, (KRAMER, 1956; KUIPER, 1964).

A poor aeration causes a reduction in the metabolic activity of the root cells and may reduce the permeability. The decrease in permeability can be related to lack of oxygen (MEEs and WEATHERLY, 1957; LETEY, a.o., 1961), as well as to high concentrations of carbon dioxyde (BROUWER, 1954). Both factors are present at the same time under field conditions with poor aeration. Reduction in evapotranspiration, due to poor aeration, has been observed by KUIPER and BIERHUIZEN (1958) and LETEY a.o. (1961).

The transport of water in the liquid phase in the plant, based on the considerations given above, may be described as a physical phenomenon, in which the highest flow resistance is present in the root cells. Low soil temperature and poor aeration affect the transport of water, but give in fact a similar reaction in reducing evapotranspiration as does a lack of water in the soil around the roots. In the first case, however, the reducing factor is located in the limiting permeability of the root cells. An approach to the evaluation of the total resistance for liquid flow in the plant is given in Chapter V.

\section{Effect of stomatal opening on evapotranspiration}

The significance of resistance to water movement in the root as compared with the rest of the plant has been evaluated by VAN DEN HONERT (1948) in his consideration of water transport as a catenary process. Applicated to the water movement from root medium to atmosphere, this consideration leads to the conclusion that the greatest source of resistance is in the vapour phase, from the sub-stomatal cavities to the free air. The vapour phase is the logical place for regulation of plant water loss, since control exercised elsewhere would result in dehydration of the plant between the leaf surface and the regulating resistance at an other place in the plant or even at the root surface. This implies that the flow rate through the stomata governs the total flow so the effects of other increased resistances on total flow act indirectly through their effect on the resistance in the vapour phase, instead of directly at their point of incidence.

The resistance in the vapour phase depends on stomatal opening, which in turn is related to light intensity, suction in the leaf tissue and possibly to leaf temperature. The effect of suction in the leaf tissue on stomatal resistance is discussed in Chapter V. 


\subsection{Effect of light intensity}

The aperture of the stomata is under conditions of optimum water supply determined by light intensity (STÅLFELT, 1956; KUIPER, 1961). This light sensitive reaction seems to be related essentially to photosynthesis. Reduction in stomatal opening when a shortness of water is present should be an osmotic reaction.

The increase in transpiration of tomatoes by raising of the light intensity has to be explained, according to ABD EL RAHMAN a.o. (1959), by a widening of the stomatal opening. Experiments reported by KUIPER and BIERHUIZEN (1958), performed under similar conditions show that the increase in transpiration due to the raising of leaf temperature amounts to only $14 \%$ of the transpiration in the dark. A linear relation between diffusion resistance and light intensity is present in the range of low light intensities used by these authors.

Data presented by KUIPER (1961), show that the maximum stomatal opening of bean leaves is reached at a light intensity of $7 \times 10^{4} \mathrm{erg} \cdot \mathrm{sec}^{-1} \cdot \mathrm{cm}^{-2}$, which is equivalent to a value of $0.1 \mathrm{cal} \cdot \mathrm{min}^{-1} \cdot \mathrm{cm}^{-2}$. The relation between light intensity and stomatal opening of bean leaves as given by Kuiper is presented in figure 14. Kuiper confirms moreover data reported elsewhere in literature that stomatal opening is not affected by radiation outside the range of visible light. The data of light intensity, presented by Kuiper, only refer to the visible light. The shortwave solar radiation, reaching the earth surface, contains only $40 \%$ radiation in the visible range. From this follows that bean leaves exposed to solar radiation have a maximum stomatal opening at a light intensity of $0.25 \mathrm{cal} \cdot \mathrm{min}^{-1} \cdot \mathrm{cm}^{-2}$. The relation between light intensity and diffusion resistance as derived from the data given by Kuiper, is presented in figure 15. This figure shows that the resistance decreases to a minimum value with increasing light intensity.

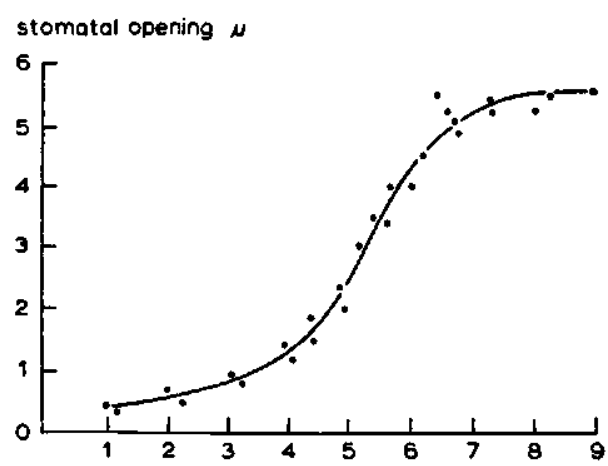

Fig. 14. Relation between stomatal opening and light intensity for a bean leaf according to KUIPER (196I)

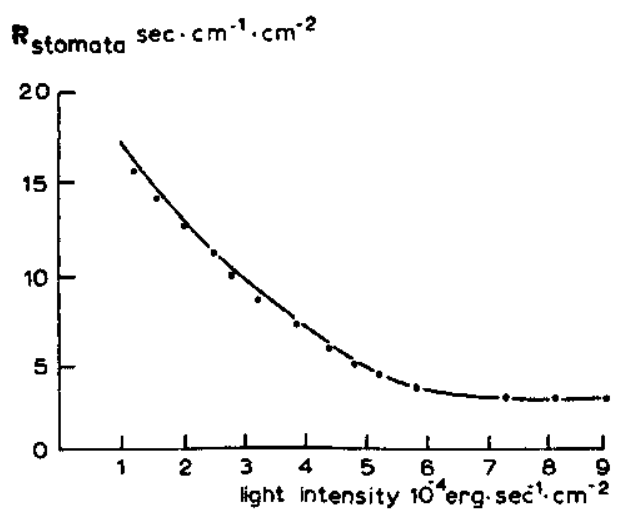

Fig. 15. Relation between light intensity and stomatal diffusion resistance for a bean leaf derived from data given by KUIPER (196I) 
Under field conditions, when using balance periods of some days, the mean light intensity during the period concerned can be introduced as a measure for the factor controlling the stomatal opening. The daily course in radiation is important because even on clear days the light intensity is during a part of the day, near sunrise and sunset below the value giving a maximum stomatal opening. During these periods on clear days, however, transpiration is low in comparison to the transpiration rate near noon. Low light intensities, especially in periods with much cloudiness during daytime, can cause a reduction in evapotranspiration due to a partial closure of the stomata. It will have to be expected, using the mean light intensity during a balance period, that this reduction is already present at higher values than $0.25 \mathrm{cal} \cdot \mathrm{min}^{-1}$. $\cdot \mathrm{cm}^{-2}$.

\subsection{Effect of leaf temperature}

The results obtained in investigations concerning the effect of temperature on stomatal opening differ widely as appears from a review on this subject presented by STÁlfelt (1956). The results seem to depend on both the type of crop used and the range in temperature applied. KUIPER (1961) concludes that stomatal opening under conditions of optimum water supply is independent of temperature. The stomata of beans and tomatoes in his experiments remained closed, however, irrespective of the light intensity applied, when the temperature was below $10^{\circ} \mathrm{C}$. Above $10^{\circ} \mathrm{C}$ no temperature reaction on stomatal opening was observed. It may be expected that for each crop a minimum temperature exists below which the stomata are closed. Under field conditions this situation can be present in spring and in autumn during part of the day. It is not possible, however, to separate in the present study eventual effects of soil temperature and leat temperature.

\section{Reduction factor of Penman}

Penman $(1948,1956)$ introduced an empirical reduction factor $f$ in order to determine from the calculated data of evaporation from a free water surface, the potential evapotranspiration from grass cut very short. The value of this reduction factor varies during the course of the year. Penman has presented the following values of $f$ :

$\begin{array}{ll}\text { from November to February } & 0.6 \\ \text { March, April, September, October } & 0.7 \\ \text { from May to August } & 0.8\end{array}$

Penman and Schofield (1951) have tried to give an equation for this reduction factor $f$ based on plant physiological and physical arguments. The authors proceed from the following propositions: 
a. The effective diffusion path for water vapour transport from the evaporating surface to bulk air $L_{a}$ is the same for both open water and a continuous crop cover, in spite of the difference in the nature of the surfaces.

b. The stomata are fully open from half an hour before sunrise to half an hour after sunset, so if the maximum possible duration of bright sunshine is $N$ hours then the day-length is $(N+1)$ hours.

c. The crop surface is regarded as a small part of an extremely large flat leaf. This is, according to Penman and Schofield, physically reasonable, since transpiration rates are mainly determined by the incoming energy supply per unit of horizontal surface area.

d. The saturation vapour pressure $\varepsilon_{s}$ of the water inside the leaf varies sinussoidally during the day with a midday maximum and a midnight minimum.

e. The vapour pressure of the air at a standard height remains constant during the day

f. The wind velocity remains constant during the day.

Penman and Schofield give, based on these propositions, the following equation for the ratio of the potential transpiration $\left(E_{\tau}\right)$ from a cropped surface to the evaporation from a free water surface $\left(E_{o}\right)$ :

$$
\frac{E_{T}}{E_{o}}=\frac{\bar{\varepsilon}_{s T}-e_{a}}{\bar{\varepsilon}_{s o}-e_{a}} \frac{L_{a}}{L_{a}+L_{s}}\left[\frac{N+1}{24}+\frac{a}{b \pi} \sin \left(\frac{N+1}{24} \pi\right)\right]
$$

where $\bar{\varepsilon}_{s T}$ is the mean saturated vapour pressure of water in the leaves, $\bar{\varepsilon}_{s o}$ is the corresponding value for the open water surface, $e_{\mathrm{a}}$ is the actual vapour pressure at standard height, $L_{a}$ is the effective path for diffusion from the evaporating surface to bulk air, $L_{s}$ is the corresponding value for diffusion through the stomata, $N$ is the maximum possible duration of bright sunshine in hours, $a$ is the amplitude of the daily variation in $\varepsilon_{s r}$ and $b$ is $\bar{\varepsilon}_{s T}-e_{a}$.

This ratio contains three factors. The first one is dependent on vapour pressure, generally exceeding unity. The introduction of this term is necessary because the daily temperature cycle of a crop differs from that of an open water surface under equal meteorological conditions. The second term is necessary due to the extra diffusion path through the stomata and the number of stomata per unit area of the surface. This second term is less than unity. The third term is depending on daylength, taking into account both the stomatal closure during the night and the effect of the variation in saturated vapour pressure. This third term is always less than unity.

Penman and Schofield have calculated values of this ratio that are of the same order as the experimentally determined values of the reduction factor $f$. Based on these calculations PeNMAN (1956) concludes that the reduction factor $f$ is mainly determined by the day-length factor.

The propositions, on which the theory given by Penman and Schofield is founded, are disputable at a number of points. Some of the considerations require a further discussion.

The length of the effective diffusion path $L_{a}$ in the laminar and turbulent air 
layers of the external atmosphere has been calculated from the function of wind velocity holding for a free water surface. Both the type of air movement and the laminar diffusion path within the crop may differ considerably from the corresponding factors above a free water surface.

The major part of the energy used for vaporization is available during day-time. The introduction of a day-length factor, based on stomatal closure during the night, as a predominant term in the reduction factor is very doubtful. Measurements of pan evaporation performed at the lysimeterstation between sunset and sunrise give very low values in comparison to the data over 24 hours. The ratio $E_{o-n i g h t} / E_{o-24 \text { hours }}$ amounted from 0.05 to 0.07 in a number of nights with a mean relative humidity of $80 \%$. This ratio, however, was considerably less in the majority of the observations when the relative humidity was at the normal value of $96 \%$. Small values of evapotranspiration from grass during night-time were observed by PASQUILL (1949), Rider (1954), Monteith (1956) and MCIlroy and ANGUS (1964). TANNER and Pelton (1960) observed with alfalfa a mean value of the ratio $E_{\text {night }} / E_{24 \text { hours }}$ of 0.02 during the period from July to September. ENGLand (1963) determined in lysimeter experiments a mean ratio of 0.05 for grass and clover and from 0.08 to 0.09 for corn, oats and alfalfa. Because of the very small amount of energy available for vaporization during the night under the climatological conditions in the Netherlands, the closure of the stomata during that period has only little influence on evapotranspiration.

Penman and Schofield considered the crop surface as a part of an extremely large horizontal flat leaf. Using this proposition, a deviation has been introduced to the real geometry of the diffusion process depending both on crop type and the selection of the height of the projection surface. For practical arguments it is advisable to have a coincidence of the projection surface and the apparent zero-plane of wind velocity somewhere in the crop. It is necessary, due to the modification in geometry, to introduce an apparent diffusion resistance $R_{c}$ of the crop. This factor is dependent on both stomatal opening and number of stomata, as well as on the type of crop and on the soil cover. There is some indication, however, presented by MARLATT (1961), that row crops covering more than $50 \%$ of the soil act as a full cover crop in relation to evapotranspiration, this being due to the interactions of the micro-climate within the rows. The evaluation of this apparent diffusion resistance has to be performed experimentally. An equation for evapotranspiration, taking into account the introduction of the apparent diffusion resistance, can be derived when starting from a hypothetical plane below the evaporating surface where always a saturated vapour pressure is present holding for the temperature at the evaporating surface. The equation for evapotranspiration can be expressed as:

$$
E=f\left(z_{0}, d\right) u\left(e_{s}-e_{a}\right)=\frac{e_{s}-e_{a}}{R_{a}}=\frac{\varepsilon_{\text {int }}-e_{s}}{R_{c}}=\frac{\varepsilon_{\text {int }}-e_{a}}{R_{a}+R_{c}}
$$

where $R_{a}$ is the diffusion resistance for transport from the evaporating surface to bulk air, $R_{c}$ is the corresponding value for vapour transport from the hypothetical plane 
to the evaporating surface, $e_{s}$ is the apparent vapour pressure at the evaporating surface, $\varepsilon_{i n t}$ is the saturated vapour pressure at the hypothetical plane at temperature $T_{s}$ and $e_{a}$ is the vapour pressure of the atmosphere at standard height.

From equation (27) the following expression for evapotranspiration can be written:

$$
E=\frac{f\left(z_{0}, d\right) u}{1+f\left(z_{0}, d\right) u R_{c}}\left\{\varepsilon_{i n t}-e_{a}\right\}
$$

Analogous to the procedure presented by Penman (1948), a combined equation for evapotranspiration can be derived from the equations (11b), (18) and (27a). Equation (18) is written as:

$$
K=L \gamma f\left(z_{0}, d\right) u\left(T_{s}-T_{a}\right)=\frac{L \gamma}{\Delta} f\left(z_{0}, d\right) u\left\{\varepsilon_{i n t}-\varepsilon_{a}\right\}
$$

From which follows:

$$
K=\frac{L \gamma}{\Delta} f\left(z_{0}, d\right) u\left\{\varepsilon_{i n t}-e_{a}\right\}-\frac{L \gamma}{\Delta} f\left(z_{0}, d\right) u\left\{\varepsilon_{a}-e_{a}\right\}
$$

Combination of this expression with (27a) gives:

$$
K=\frac{L \gamma}{\Delta}\left\{1+f\left(z_{0}, d\right) u R_{c}\right\} E-\frac{L \gamma}{\Delta} E_{a}^{\prime}
$$

Substitution of this equation in (1lb) expresses evapotranspiration as:

$$
E=\frac{\Delta H_{n t} / L+\gamma E_{a}^{\prime}}{\Delta+\gamma\left\{1+f\left(z_{0}, d\right) u R_{c}\right\}}
$$

where $H_{n t}$ has to be calculated using the reflection coefficient of the crop considered.

In order to explain the experimentally determined reduction tactors presented by Penman, it is necessary to give attention to the influence of the difference in reflection between a short grass surface and an open water surface, on evapotranspiration. The very short grass cover used in the experiments performed by Penman, has a surface roughness which is nearly equal to the corresponding value of a free water surface, so the same wind function can be used for both surfaces. In order to get an impression of the significance of the difference in reflection, the ratio $E_{p}^{\prime} / E_{o}$ was computed for monthly values using the Penman equation (19) for the calculation of evaporation from a free water surface, as well as for the calculation of the corresponding value from a freely evaporating surface $\left(E_{p}^{\prime}\right)$ with a reflection coefficient equal to the value for short grass $(r=0.20)$. The ratio $E_{p}^{\prime} / E_{o}$ in relation to $E_{o}$ is presented in figure 16. Assuming that under the climatological conditions in the Netherlands the mean values of $E_{0}$ are from November to February from 0 to $0.8 \mathrm{~mm}$. - day ${ }^{-1}$, during the months March, April, September and October from 0.8 to $2.0 \mathrm{~mm}$. $\cdot$ day $^{-1}$ and from May to August more than $2.0 \mathrm{~mm} \cdot$ day $^{-1}$, leads to the conclusion that the empirically determined reduction factor $f$ is mainly determined by the difference in reflection of the two surfaces. Possibly this difference in reflection also 
explains to some extent the variation in the reduction factor determined for short periods during the summer, as presented by Scholte Ubing (1959).

Moreover, it follows from figure 16 that the factor day-length has little influence on the value of the reduction factor, which agrees with the small amount of energy available for vaporization during the night.

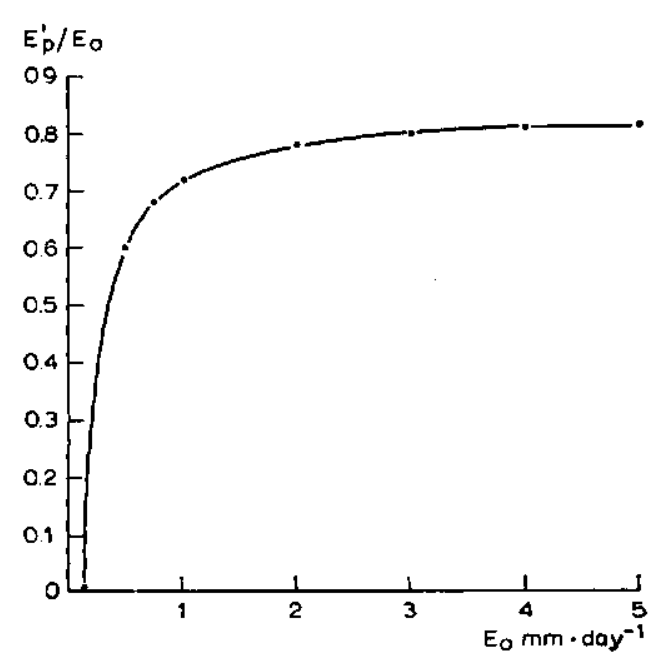

Fig. 16. Relation between the ratio $E_{\mathrm{p}}^{\prime} / E_{\mathrm{o}}$ and the calculated evaporation from a free water surface $\left(E_{o}\right)$

This calculation further indicates that the apparent diffusion resistance approaches to zero under conditions of optimum water supply, agreeing with the value 0.92 determined by BUSINGER (1956) for the term $\left(1+f\left(z_{0}, d\right) u R_{c}\right)$. Lysimeter experiments with grass under conditions of high light intensity and optimum water supply, performed by BuRGY and POMEROY (1958), in which the crop surface of one of the lysimeters was wetted continuously, do not show a systematic deviation in evapotranspiration from the data obtained from a lysimeter with a dry leaf surface. These results also indicate that the apparent diffusion resistance under these conditions has little effect on evapotranspiration. VAN BAVEL a.o. (1963) measuring evapotranspiration from Sudan Grass conclude that the evapotranspiration is an externally controlled process in which the stomatal resistance has no influence.

\section{Effect of interception on evapotranspiration}

A part of the precipitation remains on the leaf surface and does not reach the soil. Particularly under conditions when, due to both low light intensity and shortness of available moisture in the root zone, a strong reduction in evapotranspiration is present, the interception increases evapotranspiration in comparison with a dry crop under the same conditions. The amount of water remaining at the leaf surface highly depends on the amount of precipitation. The relation between interception and pre- 
cipitation, determined in the interception experiments described in Chapter II.8, is presented in figure 17. Data, reported by CLARK (1940), BURGY and POMEROY (1958) and BEARD (1962) are also presented in this figure. The generally higher values given by CLARK concern field experiments with prairy grasses. Possibly the type of the grasses, as well as the experimental conditions may have affected the data obtained in these experiments. In the analysis of the lysimeter data, the curve given in figure 17 is used for the calculation of the interception. No corrections are applied for effects of crop height and crop density in relation to interception.

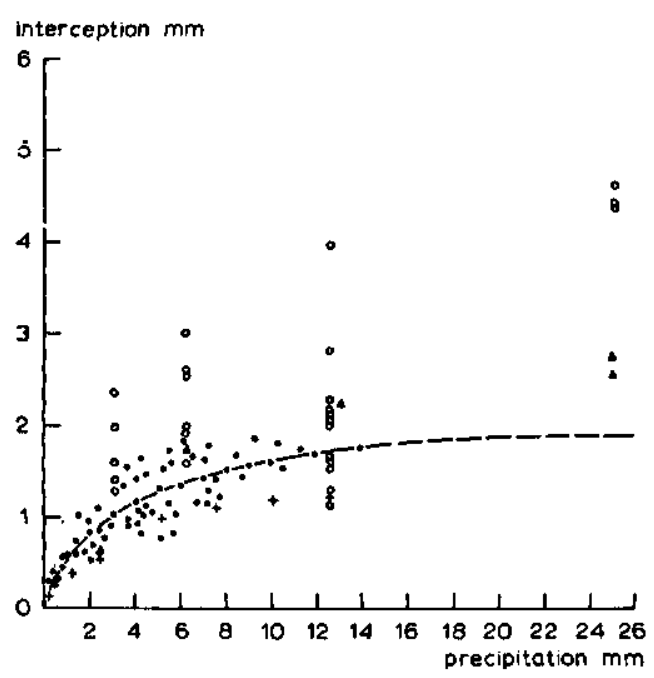

Fig. 17. Relation between interception and precipitation for grass. o ClARK (1940); $\triangle$ BEARD (1962); + BURGY and POMEROY (1958); • present measurements (grass height 16 to $20 \mathrm{~cm}$ )

It can be expected, under all conditions of evapotranspiration, that the transpiration from wet leaves is smaller than the corresponding value from dry leaves. The energy available for vaporization is partly used for evaporation of the intercepted precipitation which causes a reduction in the amount of energy available for transpiration from wet leaves this in contrast to the amount available for transpiration from dry leaves under the same conditions. Moreover, transpiration from wet leaves is reduced by the increased water vapour content in the micro-climate of the crop causing a reduction in the vapour pressure gradient between the sub-stomatal cavities and the leaf surface.

It is necessary in an analysis of the effects of environmental conditions on evapotranspiration to separate transpiration and evaporation. In separating both terms it will be assumed that under conditions of a good soil cover the evaporation coming directly from the soil surface can be ignored. This proposition is generally not correct for a very short crop in combination with wet conditions of the topsoil. Under these conditions the assumed evaporation is too low.

The effect of the intercepted precipitation on evapotranspiration can be calculated starting from the following equations: 


$$
E=E_{\mathrm{I}}+E_{\mathrm{T}}=\frac{e_{s}-e_{a}}{R_{a}}
$$

and

$$
E_{T}=\frac{\varepsilon_{i n t}-e_{s}}{R_{c}}
$$

where $E_{I}$ is the evaporation of the intercepted precipitation and $E_{T}$ is the transpiration from the crop. Combining both equations gives:

$$
E_{T}+\frac{R_{a} \cdot E_{I}}{R_{a}+R_{c}}=\frac{\varepsilon_{i n t}-e_{a}}{R_{a}+R_{c}}
$$

Combination of (28a) and (32) gives:

$$
K=\frac{L \gamma}{\Delta} E_{T}\left\{1+f\left(z_{0}, d\right) u R_{c}\right\}+\frac{L \gamma}{\Delta} E_{I}-\frac{L \gamma}{\Delta} E_{a}^{\prime}
$$

Substituting (33) in (11b) gives the following expression for transpiration:

$$
E_{T}=\frac{\Delta\left\{H_{n} / L-E_{\mathrm{I}}\right\}+\gamma\left\{E_{a}^{\prime}-E_{\mathrm{I}}\right\}}{\Delta+\gamma\left\{1+f\left(z_{0}, d\right) u R_{c}\right\}}
$$

The equation for evapotranspiration can be written as:

$$
E=E_{I}+E_{T}=\frac{\Delta H_{n t} / L+\gamma\left\{E_{a}^{\prime}+f\left(z_{0}, d\right) u R_{c} E_{I}\right\}}{\Delta+\gamma\left\{1+f\left(z_{0}, d\right) u R_{c}\right\}}
$$

It appears from equation (35) that the effect of interception on the increase of evapotranspiration depends on the roughness of the surface, on wind velocity and on the apparent diffusion resistance of the crop. The influence of interception grows when the reduction in transpiration due to other factors increases.

From experiments presented by Burgy and Pomeroy (1958) and MCMillan and BURGY (1962) it appears that evapotranspiration from wet grass equals the evapotranspiration from a dry grass surface. These experiments were performed at high light intensities and with optimum water supply. These results only agree with equation (35) when the apparent diffusion resistance is zero.

RYHINER and RUTEMA (1963) show in the analysis of data obtained from the lysimeters at Castricum that interception gives a considerable increase in evapotranspiration from pines. It appeared that the apparent diffusion resistance of this crop is not equal to zero, even under conditions of high light intensity and optimum water supply.

The distribution of the rain-showers has to be taken into account in the calculation of the mean interception during a balance period. Since only daily values of precipitation were measured the mean interception is calculated from these data.

VAN WIJK and DE VRIES (1954) proposed to calculate the evapotranspiration from a crop as a product of two factors given by the equation:

$$
E=A \cdot B
$$


In this equation $B$ represents the evaporation from a wet surface of similar shape and dimensions as the crop considered. This theoretical wet surface receives the same amount of energy as the crop. The factor $A$ is a reduction factor depending amongst other things on plant physiological properties and on the suction in the root zone. The authors do not present a further formulation of this factor. Based on the considerations given before, this factor $A$ can be expressed for periods without precipitation as:

$$
A=\frac{\Delta+\gamma}{\Delta+\gamma\left\{1+f\left(z_{0}, d\right) u R_{c}\right\}}
$$

Evapotranspiration from a crop increases due to interception when the apparent diffusion resistance is not equal to zero. The expression proposed by Van Wijk and De Vries has to be enlarged as follows under conditions of precipitation:

$$
E=A \cdot B+C
$$

The factor $C$ in this expression can be calculated from:

$$
C=\frac{\gamma f\left(z_{0}, d\right) u R_{c} E_{I}}{\Delta+\gamma\left\{1+f\left(z_{0}, d\right) u R_{c}\right\}}
$$

The evaporation term $E_{I}$ is difficult to determine exactly, particularly in periods with much precipitation, when the crop does not become dry between the successive showers. The estimated amount of interception is too high in that case. Since the factor $B$ is valid for the evaporation from a wet surface with the same properties as the crop considered, the evapotranspiration calculated with equation (38) may not exceed the factor $B$. This requirement can be expressed as:

$$
A \cdot B+C \leqq B
$$

\section{Summary}

The uptake of water by the plant is initiated and primarily controlled by transpiration. The flow of water can be described as a physical phenomenon mainly located in the xylem vessels and in the cell walls of the leaf tissue. Water has to flow through the living cells in the endodermis. Only in the roots the transport of water in the plant is depending on metabolic activity of the living cells. Both low root temperature and poor aeration can affect the water transport in the roots. These factors give in fact a similar reaction in reducing evapotranspiration as a lack of water in the soil around the roots does.

Considering water transport from the soil to the atmosphere as a catenary process leads to the conclusion that the greatest source of resistance exists in the vapour phase from the sub-stomatal cavities to the free air. The resistance in the vapour phase depends on stomatal opening, which in turn is related to light intensity, leaf temperature and suction in the leaf tissue. 
Light intensity is the main factor in regulating stomatal opening under conditions of optimum water supply. The mean light intensity during a balance period is introduced as a measure for the factor controlling stomatal opening under field conditions.

The results obtained in investigations concerning the effect of temperature on stomatal opening differ widely. There are indications, however, of existing minimum temperatures, depending on the type of crop, below which the stomata are closed.

The plant physiological and physical arguments presented by Penman and SchoFIELD (1951), do not explain the values of the experimentally determined reduction factor $f$ for short grass. The stomatal closure during the night has little effect on transpiration since the amount of energy available for vaporization is very small during this period. This argument leads to the conclusion that the factor day-length has little influence on the value of the reduction factor. It is shown that this factor is mainly determined by the difference in reflection between a short grass surface and an open water surface.

The apparent diffusion resistance of a crop is introduced in relation to the geometry of the evaporating surface as well as to the stomatal resistance. A combined equation for the calculation of evapotranspiration is derived taking this factor into account. Some indications are present that the apparent diffusion resistance for grass equals zero under conditions of high light intensity and optimum water supply.

Evaporation of intercepted precipitation has an increasing effect on evapotranspiration when the apparent diffusion resistance is not equal to zero. An approach to formulate this effect is presented assuming that evaporation from the soil surface beneath a full cover crop can be ignored. An equation is derived for the calculation of this effect on evapotranspiration. 


\section{Soil physical aspects of evapotranspiration}

The soil moisture content is changing during the course of the year under influence of precipitation, evapotranspiration and drainage. The amount of precipitation during the growing season is generally not sufficient to cover the water requirements of crops under the climatological conditions in the Netherlands. For this reason the water supply of crops depends for a major part on the availability of soil moisture, which in turn is related to the depth and intensity of the root system, the hydrological properties of the soil, particularly the flow velocity to the roots and the depth of the groundwater table. Moreover, this availability depends on the transpiration rate which causes the drying up of the root zone. Due to this uptake of water by the crop a potential gradient is established below the root zone causing a rise of water from the groundwater table to the root zone, which results in an additional supply of water.

\section{Capillary conductivity of soils}

GARDNER a.o. (1922) introduced the concept of moisture potential for the sum of all forces by which the water is held in the soil. The moisture potential is defined as the energy required to bring a unit volume of water from a level of zero potential to the place of which the potential is wanted. At a height of $h \mathrm{~cm}$ above the level of zero potential the moisture potential is $h \mathrm{~cm}$ under equilibrium conditions. This means that in a state of equilibrium, when no flow of water is present in the soil, the suction of the soil moisture equals at each height above the groundwater table the potential due to gravity.

According to RicHARDS (1931) the flow of water in unsaturated as well as saturated soils may be described by Darcy's law, which is written as:

$$
v=-k \frac{\partial \varphi}{\partial z}
$$

where $v$ is the volumetric flow velocity, $\varphi$ is the potential, $z$ is the direction of flow and $k$ is the capillary conductivity. The flow velocity is positive in the positive direction of $z$.

The hydraulic conductivity $k$ is in saturated media a constant depending on the type of soil. The capillary conductivity in unsaturated soils, however, strongly depends on soil moisture content, which in turn is related by the soil moisture characteristic to the suction. 
One of the methods for the determination of capillary conductivity is based on the measurements of suction or soil moisture at various heights in the profile when the flow velocity is known. This method is developed by MOORE (1939) and it has been also applied by RICHARDS and WeEks (1953) in laboratory experiments. WIND (1955) and TALSMA (1963) have applied this method under field conditions, using respectively nylon units and tensiometers for the measurements of the suction.

The data of soil moisture content, determined periodically with nylon units at various heights above the groundwater table are used in the present study for the determination of the capillary conductivity of the soils in the lysimeters. In the calculations only those periods are used of which the total withdrawal of moisture from the profile according to the measurements of the nylon units, was equal to the loss of water determined by weighing of the lysimeters. Moreover, periods in which precipitation was present were not taken into consideration. In this way it was possible to select periods of 3 and $\mathbf{4}$ days in which no hysteresis effects were present.

The suction at the various heights in the profile was determined from the data of soil moisture content using the soil moisture characteristics presented in figure 1 . In the calculations performed the flow velocity is not the same for all depths, but is the sum of the capillary rise $(c)$ from the groundwater and the amount of moisture $(m)$ extracted in unit time from below the depth concerned. For steady-state conditions and upward vertical flow equation (41) can be modified as follows:

$$
v=c+m=k\left(\frac{d \psi}{d z}-1\right)
$$

Using during short periods the mean moisture content and the suction corresponding with it does generally not lead to a serious error.

WIND (1955) and WESSELING (1957) give as the approximate relation between capillary conductivity and suction the empirical equation:

$$
k=a \psi^{-n}
$$

where $a$ is a constant, that is according to Visser (1959) related to the conductivity of nearly saturated soil. The exponent $n$ has a value from 1.5 to 2 in clay soils and has higher values in sandy soils. Equation (42), however, has the property that, when $\psi$ equals zero, the saturated conductivity becomes infinite. For this reason GARDNER (1958) proposed a somewhat modified equation expressing the relation between both factors as:

$$
k=\frac{a}{\psi^{n}+b}
$$

According to this equation the saturated conductivity equals $a / b$ at zero suction. The relation proposed by GARDNER requires, in order to be fulfilled, a small suction range near saturation in which the capillary conductivity does not alter considerably. TALSMA (1963) presenting a full discussion on equation (43) concludes that this relation holds only for a part of the data given. For other data it is shown that the 
conductivity decreases rapidly at low suctions and relationships intermediate between those given in the equations (42) and (43) are found.

In connection with the data of capillary conductivity available from literature as well as with those calculated in the present study a further examination of these data is necessary.

The data reported in literature concern in many cases measurements in samples or columns filled with artificially packed soils. The measurements mostly cover a limited range from saturation to a suction of 100 to $200 \mathrm{~cm}$ (RICHARDS and WILSON, 1936; WILSON and RiCHARDS, 1938; ChrISTENSEN, 1944; RICHARDS and MOORE, 1952; NiElSEN a.o. 1960; BUtun, 1961; TALSMA, 1963; Rubin a.o., 1964). It appears from the data presented by these authors that the relation between capillary conductivity and suction in this range can be expressed for many soils as:

$$
k=k_{0} e^{-\alpha \psi}
$$

The data given by TALSMA (1963) are presented in figure 18. He did show that the capillary conductivity decreases very rapidly in a number of soils in the range of very low suctions. The conductivity $k_{o}$ at saturation, obtained by extrapolation of the relationship given in (44), is not in all soils equal to the hydraulic conductivity $k_{s}$ determined under saturated conditions. The extent to which $k_{s}$ exceeds the value of $k_{0}$ depends on the existence of an apparent non-capillary pore space, such as rootholes and cracks losing water immediately when a very small suction is present. The systematic deviation between both factors present at very low suctions has little influence
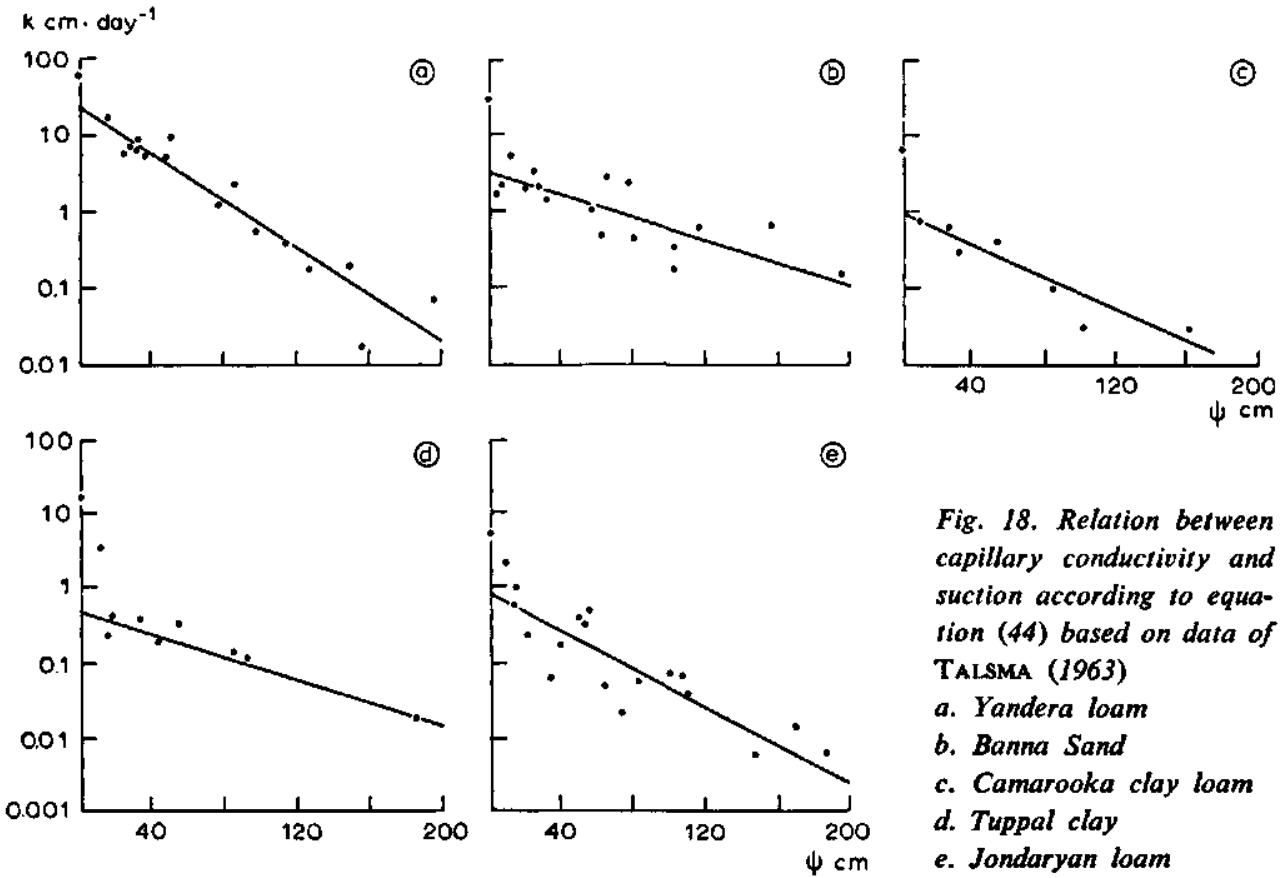

Fig. 18. Relation between capillary conductivity and suction according to equafion (44) based on data of TALSMA (1963)

a. Yandera loam

b. Banna Sand

c. Camarooka clay loam

d. Tuppal clay

e. Jondaryan loam 
$\log \alpha \cdot \log 0.434 \psi$

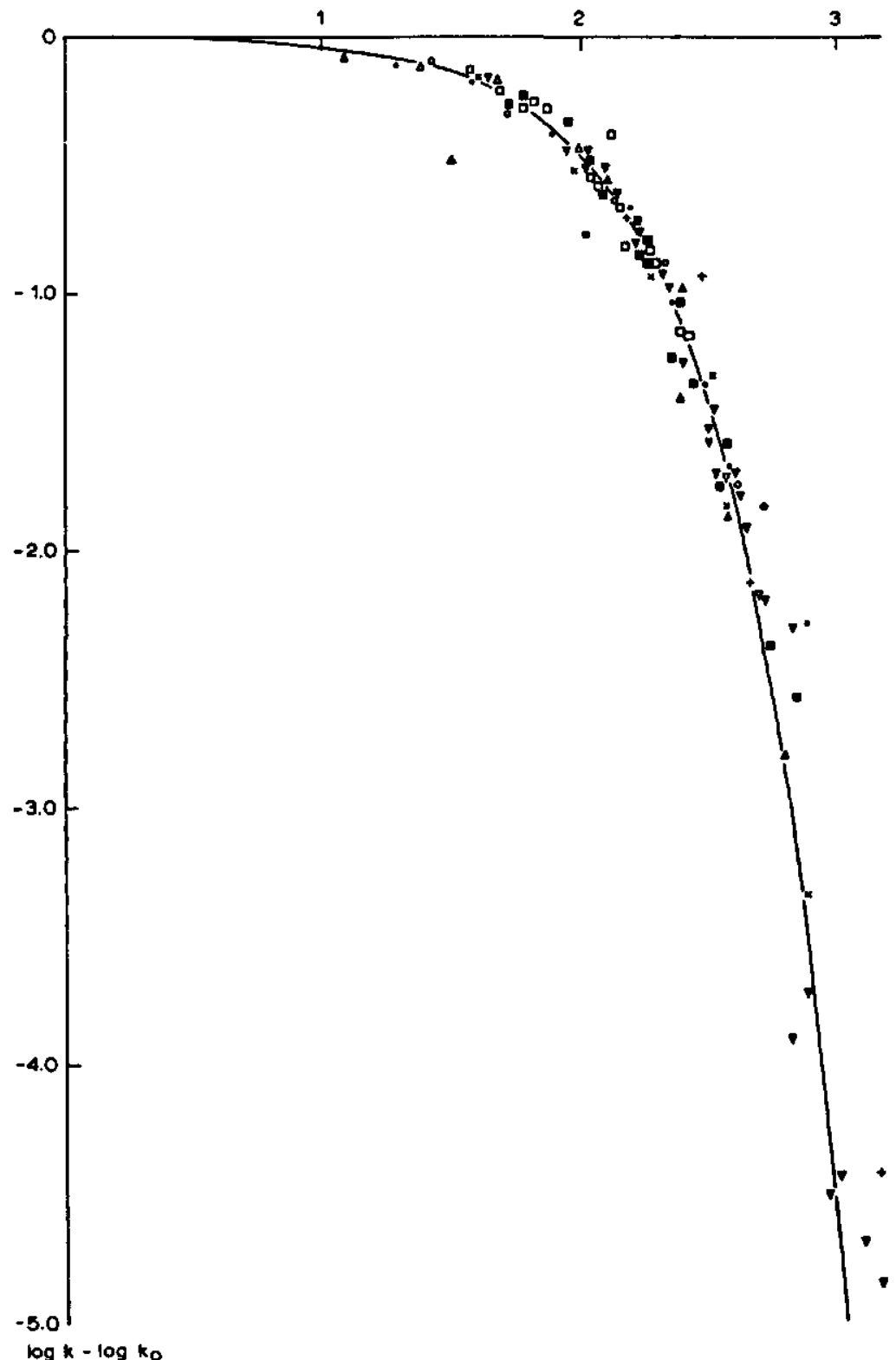

Fig. 19. Relation between capillary conductivity and suction for various soils. The curve is calculated with equation (44a)

RICHARDS and MOORE (1952)

- Preston clay

- Chino silty clay

$\triangle$ Millville silt loam

NiElsen a.o. (1960)

A Pachappa fine sandy loam

$x$ Coachella loamy fine sand

+ Superstition sand 
on the considerations concerning capillary rise, so the extrapolated values can be used in calculations on this subject.

Data concerning capillary conductivity, reported by RICHARDS and MOORE (1952) and NIELSEN a.o. (1960), in the unsaturated range to a suction of $100 \mathrm{~cm}$ are presented in figure 19 on dimensionless reduced scales. The curve given in this figure is calculated with the expression

$$
\log k / k_{0}=-0,00434 \psi
$$

Figure 19 shows that the relation, between capillary conductivity and suction, given in equation (44), holds well in the covered suction range.

It sometimes appears that the value of capillary conductivity in sandy soils and in artificially packed soil columns remains constant in a small suction range from saturation to a certain value of $\psi$. Above this suction the conductivity values decrease very rapidly with increasing suctions. VISSER (1963) introduced this point as the airentry value, defined as the suction at which air enters a sample of undisturbed soil and water is withdrawn from it. For soils in which this phenomenon is present equation (44) has to be replaced by the following expressions:

$$
\begin{array}{ll}
k=k_{0} & \psi \leqq \psi_{a} \\
k=k_{0} e^{-a\left(\psi-\psi_{a}\right)} & \psi>\psi_{a}
\end{array}
$$

where $\psi_{a}$ is the suction at the air-entry point.

Data on capillary conductivity in Rehovot sand, published by RUBIN a.o. (1964) are presented in figure 20 . The relations given in (45) satisfy to a suction of $80 \mathrm{~cm}$. The data on capillary conductivity and suction in sandy loam and dune sand given by BUTuN (1961) can also be described with (45).

Only a few data are available from literature concerning the relation between capillary conductivity and suction in the range from field capacity to wilting point. The relation between capillary conductivity and suction of two soils given by GARDNER and FIREMAN (1958) is presented in figure 21. In the low suction range these relations also agree with (45). The data deviate from this relationship, however, in the range of high suctions. In this range the relation can be described by equation (42). The data concerning river basin clay and medium coarse sand, reported by respectively WIND (1955) and WIND and HIDDING (1961), can also be described by (42) in the high suction range. No data are given by these authors at very low suctions, so a testing of the relations given in (44) and (45) cannot be performed with these data. However, the relation between capillary conductivity and suction in the suction range from 30 to $100 \mathrm{~cm}$ deviates, particularly in the medium coarse sand, from the corresponding relation in the range of high suctions.

The calculated values of capillary conductivity of the soils used in this study are presented in figure 22 , showing the relation between capillary conductivity and suction. It is necessary to make a distinction between the humous topsoil and the dense subsoil of the loamy sand. The data concerning the saturated conductivity were 


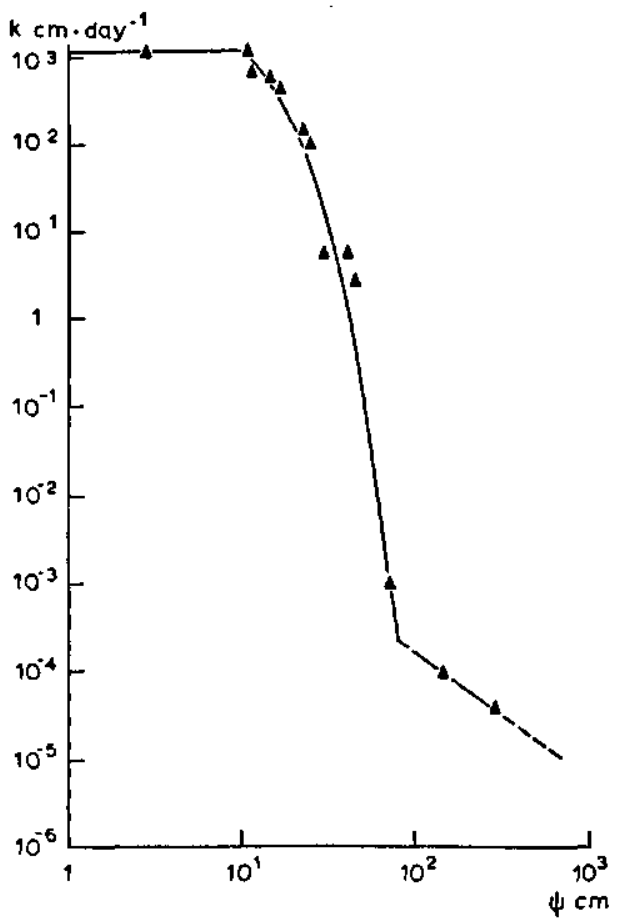

Fig. 20. Relation between capillary conductivity and suction for Rehovot sand according to data of RUBIN a.o. (1964). The curve is calculated to a suction of $80 \mathrm{~cm}$ with equation (45) with $k_{0}=$ $1120 \mathrm{~cm} \cdot$ day $^{-1}, \alpha=0.224 \mathrm{~cm}^{-1}$ and $\psi_{\mathrm{s}}=10 \mathrm{~cm}$

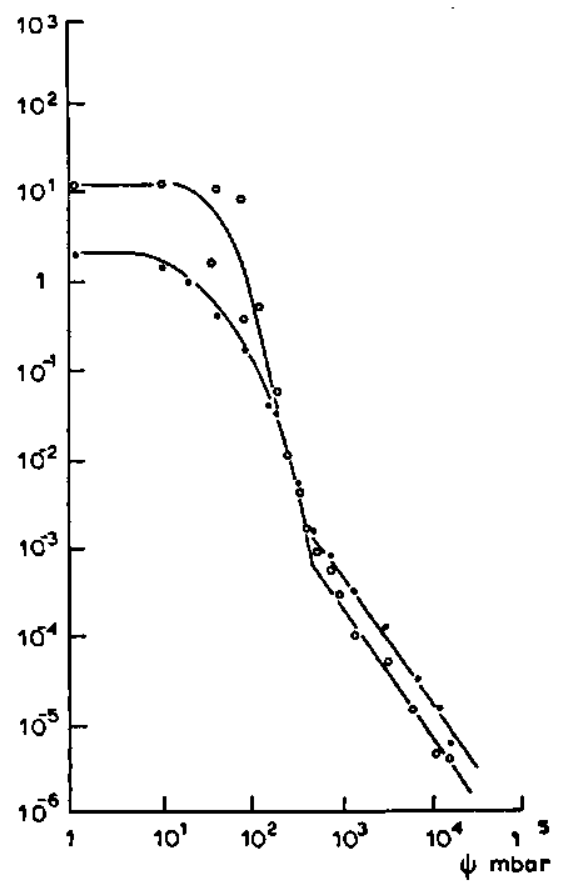

Fig. 21. Relation between capillary conductivity and suction according to data of GARDNER and FIREMAN (1958). The curve is calculased to a suction of 300 mbar with equation (45)

- Chino clay; $k_{0}=1.5 \mathrm{~cm} \cdot$ day $^{-1}, \alpha=0.0237$ $m b a r^{-1}, \psi_{s}=0$ mbar

- Pachappa fine sandy loam; $k_{0}=12.0 \mathrm{~cm}$. day $^{-1}, \alpha=0.0248 \mathrm{mbar}^{-1}, \psi_{\mathrm{a}}=10 \mathrm{mbar}$

determined in laboratory experiments, using undisturbed samples. It is not possible to derive the value of the air-entry point from these data because of the unavailability of data at very low suctions and of the scatter in the data of the saturated conductivity. In the low suction range the relation between both factors is described by equation (44). The constants in this relation for the different soils are presented in table 6 . This table gives also the maximum value of the suction $\psi_{\max }$ to which equation (44) holds.

The suction range in which equation (44) holds in the different types of soils varies strongly. This suction range depends possibly on the distribution and size of the soil particles. It appears from the available data that $\psi_{\max }$ increases with decreasing coarseness of the soil. The value of $\psi_{\max }$ is possibly again at a lower level in soils with a compound structure.

The relation between capillary conductivity and suction can in the high suction 
Table 6. Values of $k_{0}, \alpha$ and $\varphi_{\text {mas }}$ for the relation between capillary conductivity and suction according to equation (44)

\begin{tabular}{cccc}
\hline Soil type & $k_{0}\left(\mathrm{~cm} \cdot\right.$ day $\left.^{-1}\right)$ & $\alpha\left(\mathrm{cm}^{-1}\right)$ & $\psi_{\text {maa }}(\mathrm{cm})$ \\
Humous loamy sand (topsoil) & 1.0 & 0.0269 & 165 \\
Loamy sand (subsoil) & 0.36 & 0.0378 & $130 ?$ \\
Peat & 5.3 & 0.1045 & 50 \\
Sticky clay (knipklei) & 0.22 & 0.0380 & 80 \\
\hline
\end{tabular}
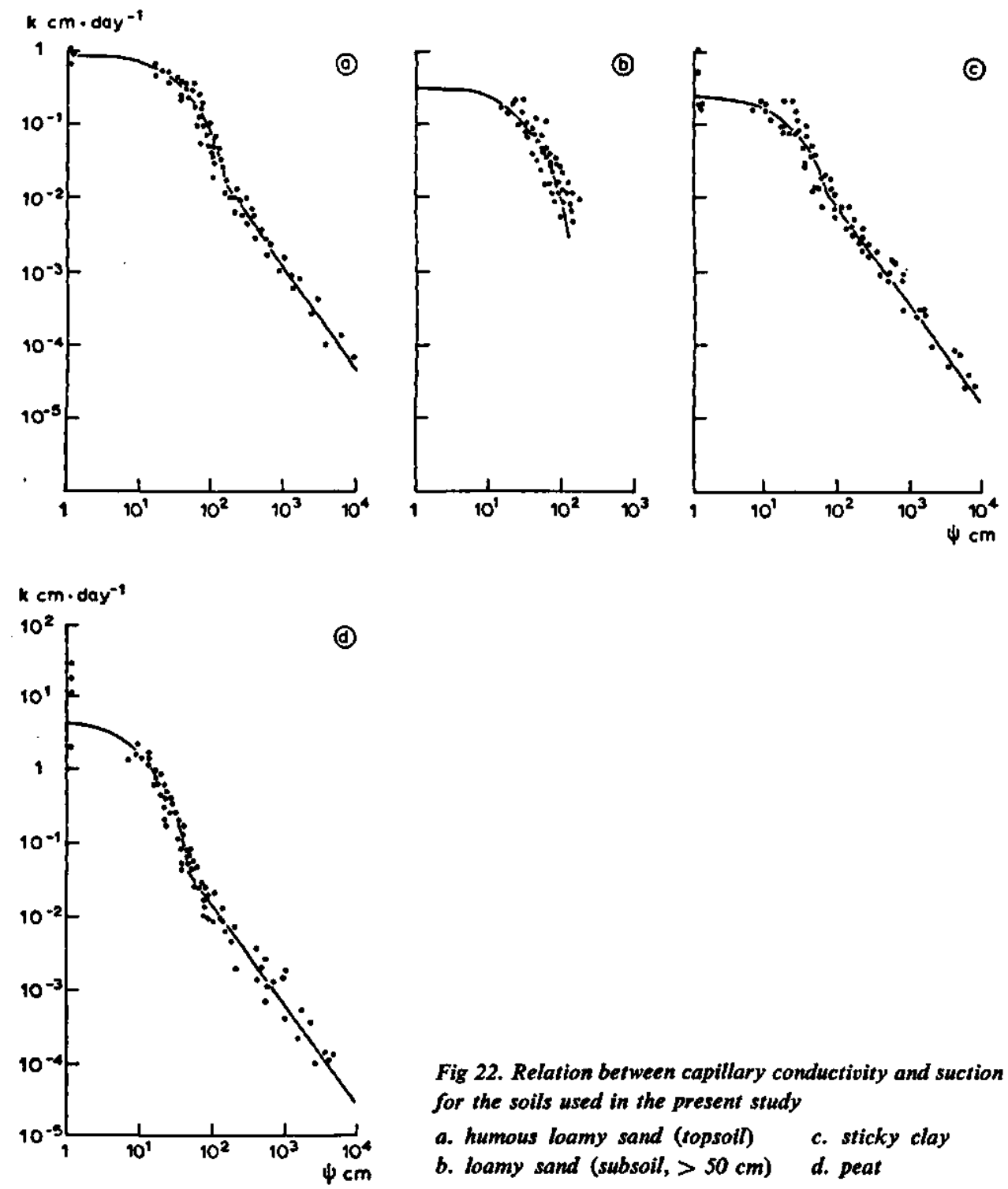

Fig 22. Relation between capillary conductivity and suction for the soils used in the present study
a. humous loamy sand (topsoll)
c. sticky clay
b. loamy sand (subsoil, $>50 \mathrm{~cm}$ )
d. peat 
range be expressed by equation (42). The values of $\log k$ determined according to this relation are presented in table 7 for suctions of $10^{2} \mathrm{~cm}$ and $10^{4} \mathrm{~cm}$. As far as the values of $\log k$ at $\psi$ is $100 \mathrm{~cm}$, are below the range in which (42) holds, the data are given between brackets. The values of the exponent $n$ are also given in this table.

Table 7. Values of $\log k_{102}, \log k_{104}$ and the exponent $n$ for different soil types

\begin{tabular}{|c|c|c|c|c|c|}
\hline Soil type & $\log k_{10^{2}}$ & $\log k_{10^{4}}$ & $n$ & $\begin{array}{l}\text { Experimental } \\
\text { conditions }\end{array}$ & Author \\
\hline $\begin{array}{l}\text { River basin clay } \\
\text { (komklei) }\end{array}$ & -1.68 & -4.38 & 1.35 & field experiment & Wind (1955) \\
\hline $\begin{array}{l}\text { Sticky clay } \\
\text { (knipklei) }\end{array}$ & -2.10 & -4.80 & 1.35 & field experiment & $\begin{array}{l}\text { Rijtema } \\
\text { (present study) }\end{array}$ \\
\hline $\begin{array}{l}\text { Chino silty clay } \\
\text { loam }\end{array}$ & $(-1.85)$ & -4.73 & 1.44 & disturbed sample & $\begin{array}{l}\text { Gardner and } \\
\text { Fireman (1958) }\end{array}$ \\
\hline $\begin{array}{l}\text { Pachappa fine } \\
\text { sandy loam }\end{array}$ & $(-2.18)$ & -5.10 & 1.46 & disturbed sample & $\begin{array}{l}\text { Gardner and } \\
\text { Fireman (1958) }\end{array}$ \\
\hline $\begin{array}{l}\text { Humous loamy } \\
\text { sand }\end{array}$ & $(-1.56)$ & -4.35 & 1.40 & field experiment & $\begin{array}{l}\text { Rijtema } \\
\text { (present study) }\end{array}$ \\
\hline $\begin{array}{l}\text { Medium coarse sand } \\
\text { (plaatzand) }\end{array}$ & -3.00 & -5.85 & 1.42 & $\begin{array}{l}\text { undisturbed } \\
\text { soil column }\end{array}$ & $\begin{array}{l}\text { Wind and } \\
\text { Hidding (1961) }\end{array}$ \\
\hline Peat & -1.84 & -4.60 & 1.38 & field experiment & $\begin{array}{l}\text { Rijtema } \\
\text { (present study) }\end{array}$ \\
\hline
\end{tabular}

The most striking result in table 7 is the fact that the exponent $\boldsymbol{n}$ for the different soil types as well as under the different experimental conditions has a nearly constant value of 1.4. This possibly indicates that the capillary conductivity in this range of high suctions is mainly determined by a film-flow on the surface of the soil particles, whereas the flow through capillaries predominates in the low suction range. STAPLE and LEHANE (1954) presenting data in the suction range from $200 \mathrm{~cm}$ to wilting point show that the capillary conductivity at constant soil moisture content increases with increasing density of the soil. This result seems also to indicate that the conductivity depends on the surface area of the soil particles per unit volume of soil.

\section{Extraction of water from the profile}

The extraction rate of moisture from the soil is often used in estimating the root distribution in the soil. Field observations show that water is withdrawn under conditions of a uniform moisture content with depth more rapidly from the shallow than from the deeper layers. VAZQUEZ and TAYLOR (1958) imitating root distribution with absorbers in laboratory experiments, show that the rate of uptake in the various layers depends on both the suction in the layer concerned, and the number of absorbers present. TAYLOR and HADDOCK (1957) conclude that under conditions of a uniform suction in the soil, the rate of moisture extraction by the roots is proportional to the root activity at the depth concerned. 
Exact values of root activity are, however, hardly to determine, since this factor varies in a complex way both in time and depth. VAN LiEsHOUt (1957) concludes from experiments that root weight and root length are not determining the root activity, but that generally a strong root activity coincides with a high root density.

2.1. Effect of suction and capillary conductivity on the extraction by uniform root systems

Physical considerations concerning the moisture extraction by a plant root are presented by PhiliP (1957), Gardner (1960), CoveY and BLOODWORTH (1962) and VISSER (1964). The extraction of water by the plant root is expressed by the following equation:

$$
\frac{\partial \theta}{\partial t}=\frac{1}{r} \frac{\partial}{\partial r} r k \frac{\partial \psi}{\partial r}
$$

where $\theta$ is the moisture content, $t$ is the time, $r$ is the radial distance from the root, $k$ is the capillary conductivity and $\psi$ is the suction in the soil.

Assuming a uniform distribution of moisture in the soil at time $t$ is zero the solution of equation (46) is subject to the following initial conditions:

$$
\theta=\theta_{0}, \psi=\psi_{0} \quad r>r_{1} \quad t=0
$$

At the root surface the flow rate per unit of area is constant, so the following boundary condition has to be fulfilled:

$$
2 \pi r_{1} k \frac{\partial \psi}{\partial r}=\frac{-E_{T}}{a z} \quad r=r_{1} \quad t>0
$$

where $E_{T}$ is the transpiration rate, $a$ is the root density in $\mathrm{cm}^{-2}$ (cm root length per $\mathrm{cm}^{3}$ soil), $z$ is the rooting depth in $\mathrm{cm}$ and $r_{1}$ is the radius of the root in $\mathrm{cm}$.

At the outer boundary of the sphere of root influence no flow of water is present, giving the following boundary condition:

$$
\frac{\partial \psi}{\partial r}=0 \quad r=r_{2} \quad t>0
$$

COVEY and BLOODWORTH (1962) propose a numerical approach of equation (46) starting from the relation:

$$
k \frac{\partial \psi}{\partial \theta}=\alpha e^{\beta \theta}
$$

Both GARDNER (1960) and VISSER (1964) proceed from the proposition of steadystate flow, in which holds:

$$
\frac{\partial \theta}{\partial t}=0
$$


In the considerations presented by Gardner, the solution of steady-state flow in a hollow cylinder has been introduced, in which the water participating in the flow comes from the outer boundary of the sphere of influence of each root. Moreover, it has been assumed that the capillary conductivity is a constant related to the mean suction in the root zone. Based on these propositions Gardner presents the following solution of equation (46):

$$
\left(\psi_{r_{2}}-\psi_{r_{1}}\right)=\frac{-E_{T}}{4 \pi k a z} \ln \left(\frac{r_{2}}{r_{1}}\right)^{2}
$$

Visser proceeds in his considerations from an extraction of moisture distributed proportionally over the content of the cylinder, while as relation between capillary conductivity and suction the function given in equation (42) is used. The arguments presented by VISSER lead to the following expression for the solution of equation (46):

$$
\frac{1}{n-1}\left\{k_{r_{2}} \psi_{r_{2}}-k_{r_{1}} \psi_{r_{1}}\right\}=\frac{-E_{T}}{4 \pi a z}\left\{\frac{r_{2}^{2}}{r_{2}^{2}-r_{1}^{2}} \ln \left(\frac{r_{2}}{r_{1}}\right)^{2}-1\right\}
$$

In the selection of the physical model used in this study, the following arguments are of importance:

a. The transpiration rate is considered as a constant during the balance periods, so neither the daily cycle in transpiration nor the redistribution of moisture in the root zone during night-time are taken into account.

b. The exact geometry of the root system as well as the distribution of the root activity with depth is unknown.

c. In measuring soil moisture contents or suctions in the root zone a certain average value of these factors is determined.

Based on these considerations it is pointless to use in the analysis of the lysimeter data the numerical approach presented by Covey and Bloodworth. With regard to the equation proposed by Visser it seems useful to introduce a weighted mean value of the capillary conductivity related to the suction measured in the root zone. Following GARDNER and EHLIG (1962) a factor $b$, depending on the geometry of the root system, the root activity and the rooting depth, can be introduced in the equation given by Gardner as well as in the solution presented by Visser. Both (52) and (53) lead to the following expression:

$$
E_{T}=\frac{\psi_{r}-\psi}{b / k}
$$

where $\psi$ is the suction measured in the root zone, $\psi_{r}$ is the mean suction at the root surface and $k$ is the capillary conductivity of the soil at suction $\psi$.

The liquid transport in the plant can be expressed as:

$$
E_{T}=\frac{\psi_{l}-\psi_{r}}{R_{p l}}
$$


where $\psi_{t}$ is the suction in the leaf tissue and $R_{p l}$ the total plant resistance for liquid flow from the root surface to the sub-stomatal cavities.

Combination of the equations (54) and (55) gives the relation presented by GARDNER and EHLIG (1962) for transpiration from crops in pot experiments. This relation is written as:

$$
E_{T}=\frac{\psi_{l}-\psi}{R_{p l}+b / k}
$$

2.2. Effect of suction and capillary conductivity on the extraction by nonuniform root systems

The analysis of the effects of capillary conductivity and suction on the moisture extraction from the soil by non-uniform root systems is much more difficult than the corresponding analysis of these effects on the extraction by uniform root systems in pot experiments. Both the suction and the rate of moisture uptake by the roots are not uniformly distributed throughout the root zone. After wetting of the soil the crop generally extracts the major part of the water required for transpiration from the top layers of the root zone, resulting in a more rapid drying up of these layers than of the deeper layers of the root zone.

Analysis of these effects is only possible if the root zone is divided in a number of layers (GARDNER, 1964; LipPS and Fox, 1964; VISSER, 1964). However, this type of study requires a detailed knowledge concerning the distribution of root density and root activity. A vertical suction gradient in the root zone arises from the moisture extraction. The vertical flow caused by the suction gradient is, however, too small to result in a uniform distribution of soil moisture in the root zone. This is due to the relatively low values of the capillary conductivity at high suctions. Particularly this vertical water transport through the soil in the root zone, highly complicates the description of moisture extraction by the plant.

GARDNER and EHLIG (1962) propose when approaching the process of water extraction by the plant to divide the root zone into two layers. The top layer contains a high concentration of roots, resulting in a more or less uniform drying up of this layer. The second layer of the root zone contains a smaller number of roots and the withdrawal of water is apparently less until the top layer becomes dry. In this second layer two path-ways are present for water transport, namely uptake and vertical transport by the roots and capillary rise through the soil to the top layers. The moisture extraction from the top layer can be described by equation (56), whereas the transport in the second layer can be considered as a flow through a porous medium with constant diffusivity when regarding the system of roots and soil as a compound porous medium. However, the suitability of this approach is strongly limited under field conditions since the thickness of the top layer varies during the growing season. This variation depends on the root development, on the change in the activity distribution as well as on the moisture content, suction and capillary conductivity in the root 
zone and on the periodical rewetting of this zone. Moreover, the moisture extraction from below the root zone has to be taken into account, in particular if the capillary rise from the groundwater table gives a non-negligeable term in the water supply. The water supply from the layers below the root zone can in principal be calculated using the steady-state solutions for capillary rise, in which the suction at the underside of the root zone affects the moisture transport.

Since the crop reaction depends on the water supply in the root zone it seems to be a better approach to introduce the mean suction in the main part of the root zone and the capillary conductivity related to it as the factors describing the availability of moisture to the plant. This main part of the root zone can be considered as the effective rooting depth, since the few roots present at greater depth do not contribute very much to the water uptake by the crop.

3. Moisture extraction from the soil by grass

The process of moisture extraction can be studied using the data of moisture content and suction derived from the measurements with nylon units. The relation between suction and height above the groundwater table is presented in figure 23 .

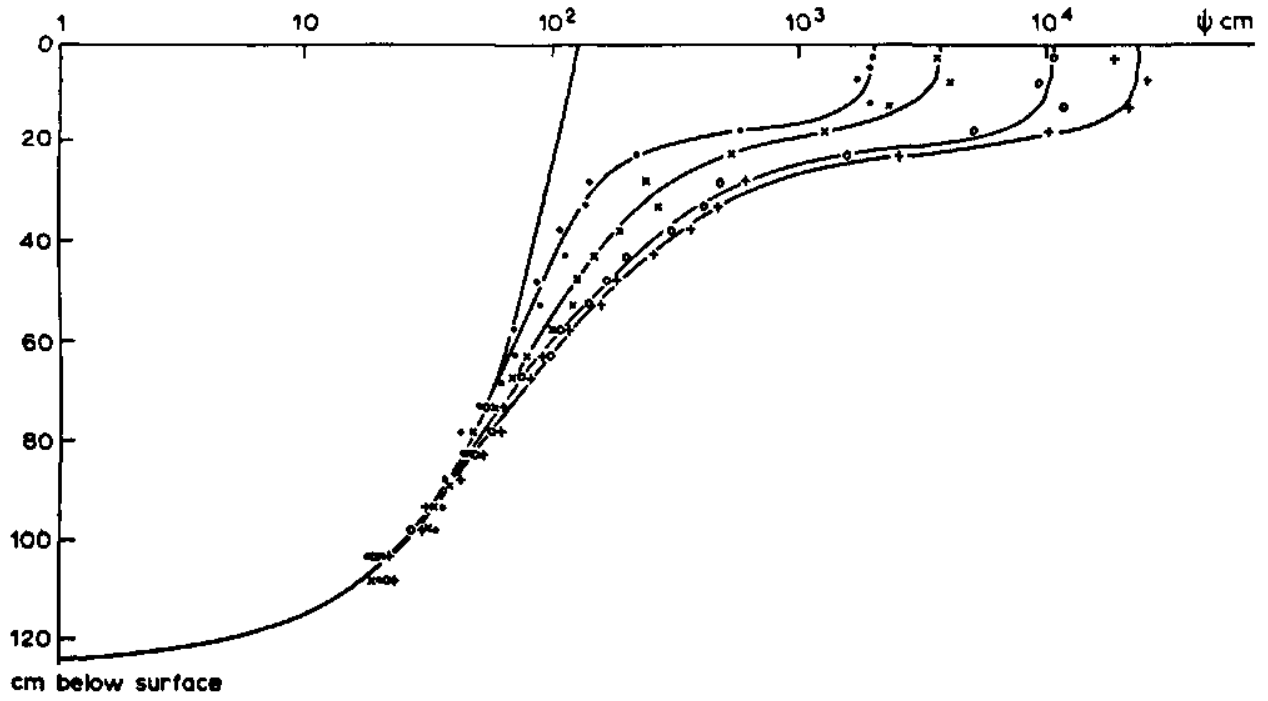

Fig. 23. Distribution of the suction in the profile of loamy sand with the groundwater table at a depth of $125 \mathrm{~cm}$
- $31 / 5$ to $3 / 6,1957$
- $4 / 7$ to $9 / 7,1957$
$\times 27 / 610 \mathrm{~J} / 7,1957$
$+9 / 7$ to $11 / 7,1957$

The curves give the mean suction during a few balance periods measured at various depths in the loamy sand when the profile is progressively drying up. The discussion 
on the moisture extraction from the soil is divided into the processes in the rooi zone and the processes below the root zone.

\subsection{Moisture extraction from the root zone}

The distribution of moisture flow, averaged over the balance periods, at different heights in the profile is presented in figure 24 . The curve for total flow is calculated from the change in moisture content, measured with the nylon units in the successive layers. The change in moisture storage in layers of $5 \mathrm{~cm}$ thickness was added to the total flow from below the depth concerned. From the suction profiles and the relation of capillary conductivity and suction, the vertical flow of water through the soil was
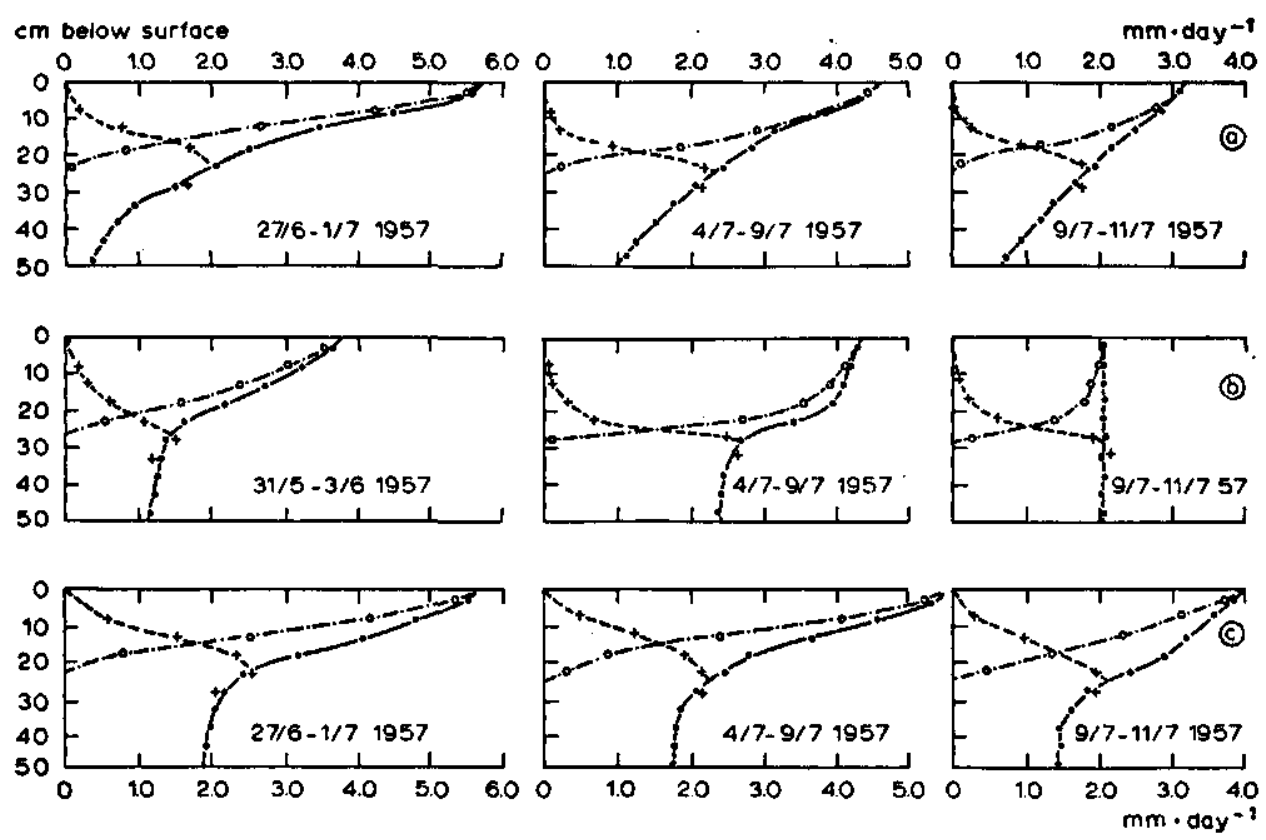

Fig. 24. Distribution of the flow velocity in the profile. a. loamy sand (water table at $125 \mathrm{~cm}$ ); b. sticky clay (water table at $50 \mathrm{~cm}$ ); $c$. peat (water table at $60 \mathrm{~cm}$ )

$\bullet-1$ total flow; $\times-\times$ vertical flow through the soil in the root zone; $0 \longrightarrow$ vertical flow through the plant roots

determined. The difference between the total flow and the calculated capillary rise gives the participation of the plant roots in the vertical transport as a function of depth. The slope of this function gives the radial flow through the soil to the roots as a function of depth below surface. The share of the grass roots in vertical transport seems to be limited to a depth of $25 \mathrm{~cm}$ in both the loamy sand and the peat soil. In the clay soil the roots affect the vertical transport to a depth of $30 \mathrm{~cm}$. These 
rooting depths have to be considered as the effective rooting depth, whereas roots present below this depth do apparently not contribute to the transport of water due to the low root intensity and a small root activity existing there. It appeared from the calculations that the capillary transport occurs in the whole root zone when low suctions are present, whereas at high suctions no capillary flow is present in the upper $15 \mathrm{~cm}$.

Equation (56) was presented for the calculation of transpiration from a crop with a uniform root system. Due to the variation in thickness of the layer without capillary rise, the mean suction in the effective root zone and the capillary conductivity related to it are introduced in the calculations performed with this equation. A rough estimate of the unknown terms $\psi_{l}, R_{p l}$ and $b$ can be obtained by using the data presented in the figures 23 and 24, dividing the root zone into a number of layers with a thickness of $5 \mathrm{~cm}$ and starting from the following propositions:

a. The suction $\psi_{l}$ in the leaf tissue is constant during a balance period.

b. The amount of water extracted from each layer by means of radial flow to the roots is transported to the leaf tissue by flow-paths that are mutually unconnected.

Based on these propositions, the transport from each layer can be expressed as:

$$
q_{n, t}=\frac{\psi_{l, \imath}-\psi_{n, t}}{r_{p l, n}+b_{n} / k_{n, t}}
$$

where $q_{n, t}$ is the radial flow to the roots of layer $n$ of $5 \mathrm{~cm}$ thickness at balance period $t, \psi_{t, t}$ is the mean suction in the leaf tissue during period $t, \psi_{n, t}$ is the mean suction in layer $n$ during period $t, r_{p l, n}$ is the apparent resistance in the plant for liquid flow from layer $n, b_{n}$ the factor related to the geometry and activity of the roots in layer $n$ and $k_{n, t}$ the capillary conductivity at suction $\psi_{n, t}$. A combination of 3 periods, covering the suction range from field capacity to wilting point, is necessary to estimate the unknown terms assuming that the values of $r_{p l, n}$ and $b_{n}$ for the grass cover are independent of time. An example of the basic data and the results obtained from the calculation is given in table 8 for a peat soil.

$R_{p l}$ can be calculated using the following expression:

$$
\frac{1}{R_{p l}}=\sum_{n=1}^{n} \frac{1}{r_{p l, n}}
$$

Moreover, $R_{p l}$ and $b$ can be calculated with equation (56), using the mean values of the suction in the effective root zone and the capillary conductivity $k$ related to it, combined with the estimated values of $\psi_{l}$.

The data of $r_{p l, n}$ and $b_{n}$ given in table 8 do not give much information concerning the distribution of both the root system and root activity in the successive layers of the root zone. It is possible that the calculations result in negative values of $r_{p h, n}$ or $b_{n}$ in the top layers, particularly when high suctions are present. This is due to the fact that the mean suction $\psi_{l}$ has a lower value than the suction in the top layers of the soil. The main reason that this situation can be present is the daily cycle in the value 


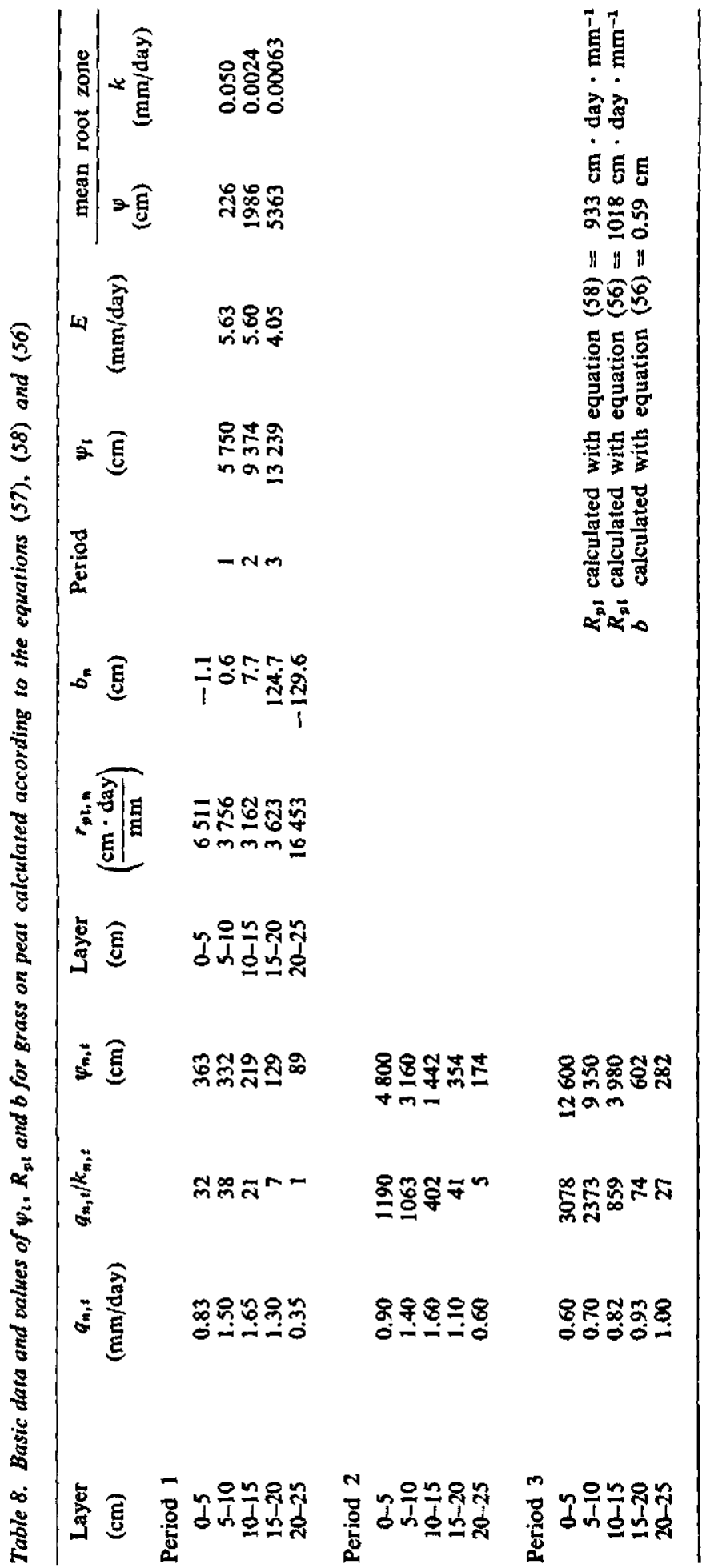


of the suction $\psi_{l}$, causing under these conditions only an uptake from these layers during the time that $\psi_{l}$ exceeds the suction in the soil, whereas no redistribution of moisture is present due to the very small values of capillary conductivity during conditions that $\psi_{l}$ is smaller than $\psi$. Moreover, the curves for capillary flow as presented in figure 24, suggest an apparent accuracy due to the low transport values in the top layers. Further the curves are very flat in the deeper layers of the root zone. The errors in the calculated capillary rise in the lower part of the root zone may in particular cause the negative value of $b_{n}$ calculated for the layer at a depth from 20 to $25 \mathrm{~cm}$ in the peat soil.

With regard to these considerations, the values of $R_{p l}$ and $b$ calculated with equation (56) are used in the analysis of the evapotranspiration data. The calculated values of $R_{p l}$ and $b$ for the three soil types are given in table 9.

Table 9. Values of $R_{p l}$ and $b$ calculated with equation (56)

\begin{tabular}{ccccc} 
& Loamy sand & Sticky clay & Peat & Mean \\
$R_{p 1}\left(\mathrm{~cm} \cdot\right.$ day $\left.\cdot \mathrm{mm}^{-1}\right)$ & 1044 & 1065 & 1018 & 1042 \\
$b$ & 0.44 & 0.37 & 0.59 & 0.47 \\
\hline
\end{tabular}

A comparison of the data given in table 9 with the data of $R_{p l}$ and $b$ for Birdsfoot Trefoil, respectively $11 \mathrm{bar} \cdot \mathrm{day} \cdot \mathrm{cm}^{-1}$ and $4 \cdot 10^{-5}$ bar, given by GARDNER and EhLIG (1963), show that the data of $R_{p l}$ agree reasonably well. The values of $b$ differ a factor 10 from each other. The main reason for this difference is, besides possible effects of the crops, due to the different experimental conditions. The calculations performed by Gardner and Ehlig concern data from pot experiments with a uniform distribution of the roots through the soil, whereas the data given in table 9 are calculated for a non-uniform root distribution in the root zone, using the mean suction and capillary conductivity.

\subsection{Moisture extraction from below the root zone}

The amount of moisture available for the crop in the layer between the underside of the effective root zone and the groundwater table can be calculated from the steadystate solutions of the capillary flow equation (41a). The integration of (41a) has to be performed in three steps when calculating the relation between suction and height above groundwater $z$, depending on the relation between suction and capillary conductivity. The following expression holds in the suction range in which $k$ remains constant:

$$
z=\frac{k_{0} \psi}{v+k_{0}} \quad \psi \leqq \psi_{a}
$$

The suction range in which the exponential function (45) holds, gives the following 
equation:

$$
z=1 / \alpha \ln \frac{v+k_{0}}{v+k_{0} e^{-a\left(\psi-\psi_{a}\right)}}+\frac{k_{0} \psi_{0}}{v+k_{0}} \quad \psi_{a} \leqq \psi \leqq \psi_{\max }
$$

The relation between $z$ and $\psi$ in the suction range above $\psi_{\max }$ has to be calculated by numerical integration.
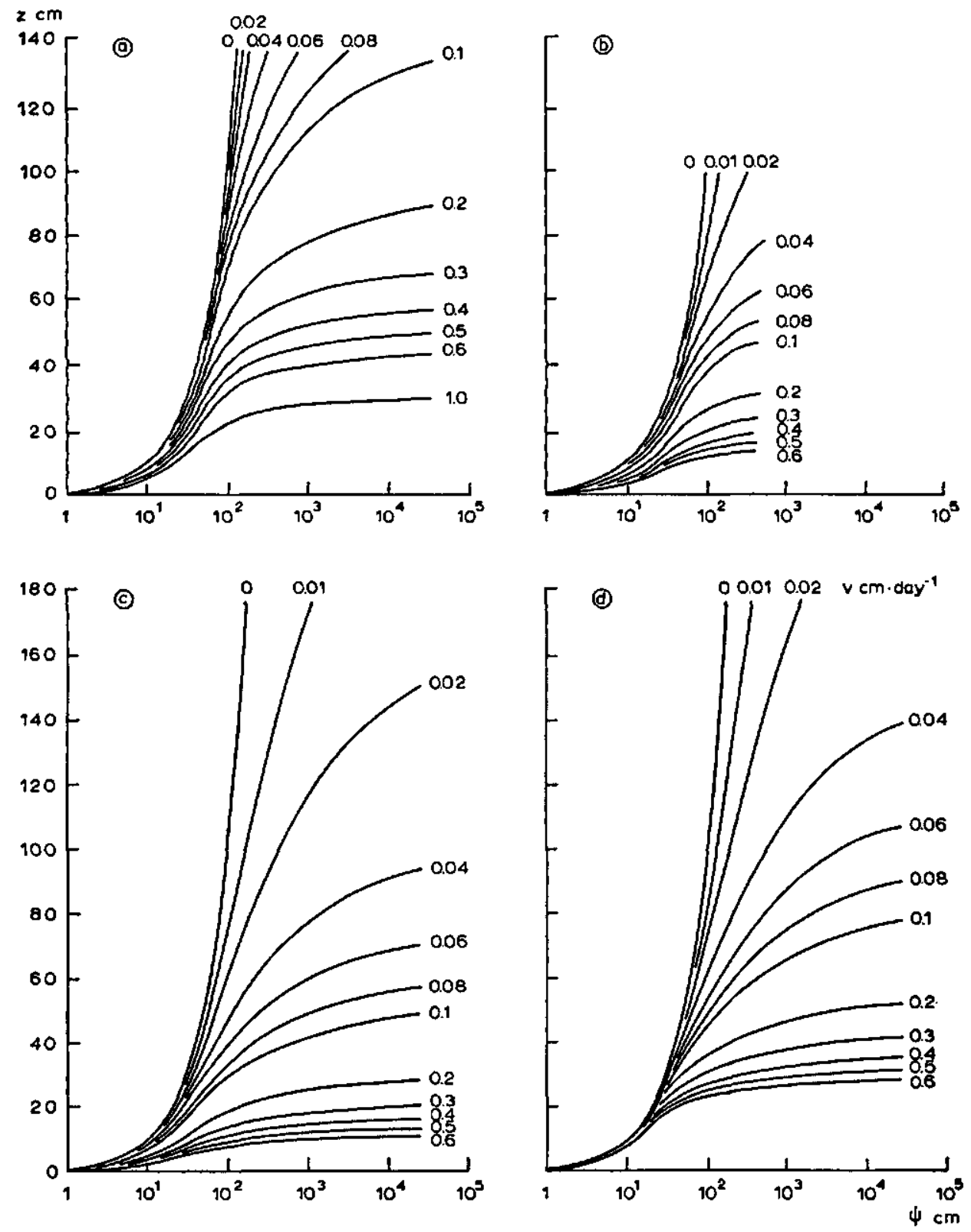

Fig. 25. The relation between the height above the water table and the suction for various oalues of capillary rise. a. humous loamy sand (topsoil); b. loamy sand (subsoil, $>50 \mathrm{~cm}$ ); c. sticky clay; d. peat 
The relations between suction and height above groundwater calculated for various flow rates are presented in figure 25. The curves of both the topsoil and the subsoil have to be combined in calculations of capillary rise in the loamy sand. The relation between flow velocity and the suction at the underside of the effective root zone for various values
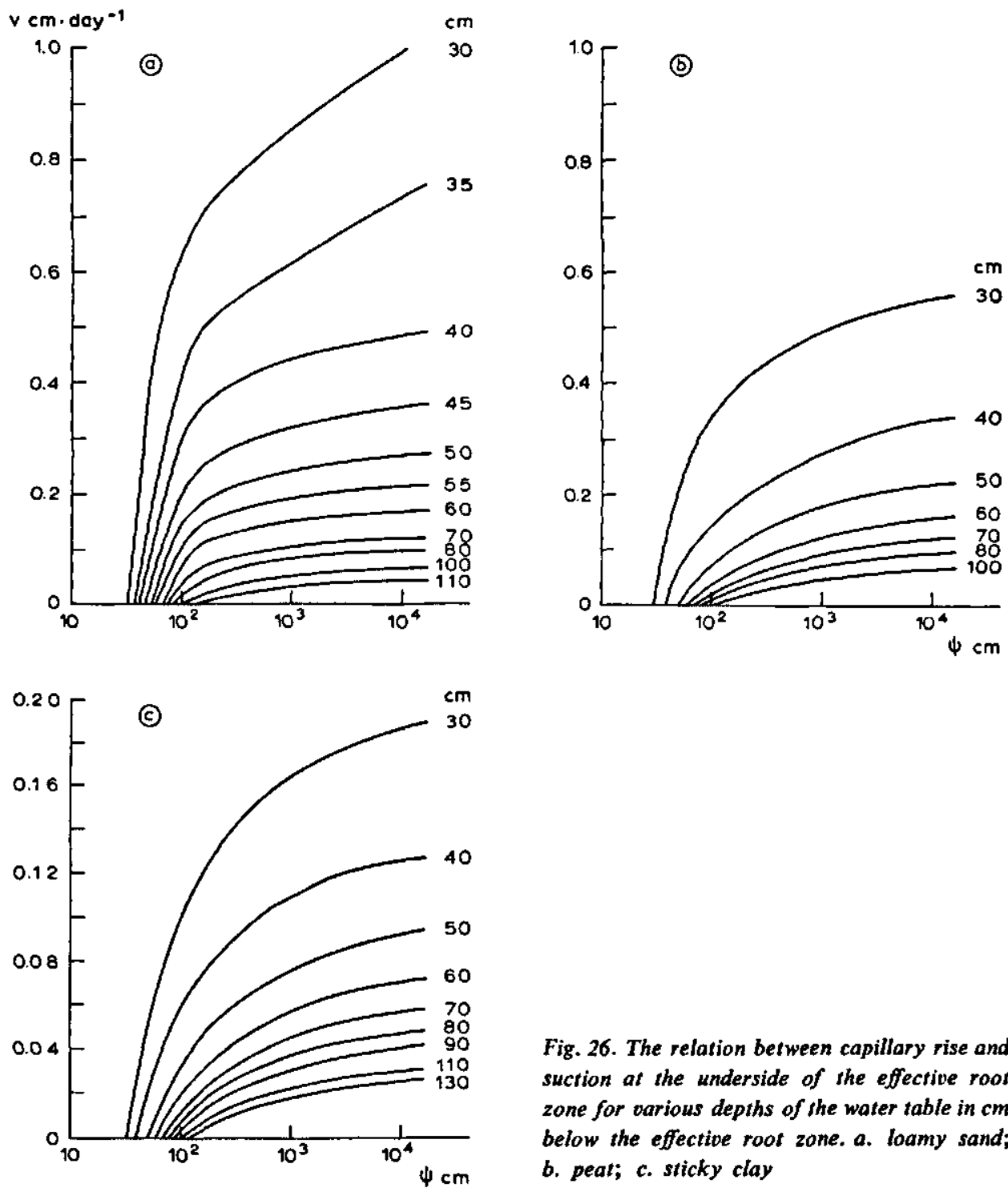

Fig. 26. The relation between capillary rise and suction at the underside of the effective root zone for various depths of the water table in $\mathrm{cm}$ below the effective root zone. a. loamy sand; b. peat; c. sticky clay

of the depth of the groundwater table expressed in $\mathrm{cm}$ below the root zone, is shown in figure 26 . The flow rate increases already strongly, particularly when high groundwater tables are present, at low suctions at the underside of the effective root zone, so the capillary supply from the groundwater can be considerable even at low suctions in 
the root zone. The capillary rise from the groundwater table depends to a great extent on transpiration when the moisture extraction between groundwater table and root zone at various flow rates is small. The transpiration rate partly determines the moisture uptake from the successive layers in the root zone. In considerations on capillary rise, it determines in particular the extraction from that layer, in which the capillary transport changes into a transport through the roots, which in turn determines the suction in the soil present in this layer. The amount of moisture extracted from below the root zone during daytime can be supplied again during the night when a relatively high capillary flow rate is present in this layer. The value of capillary rise from the groundwater is hardly affected by the drying up of the top layers of the root zone under these conditions. The relation between observed

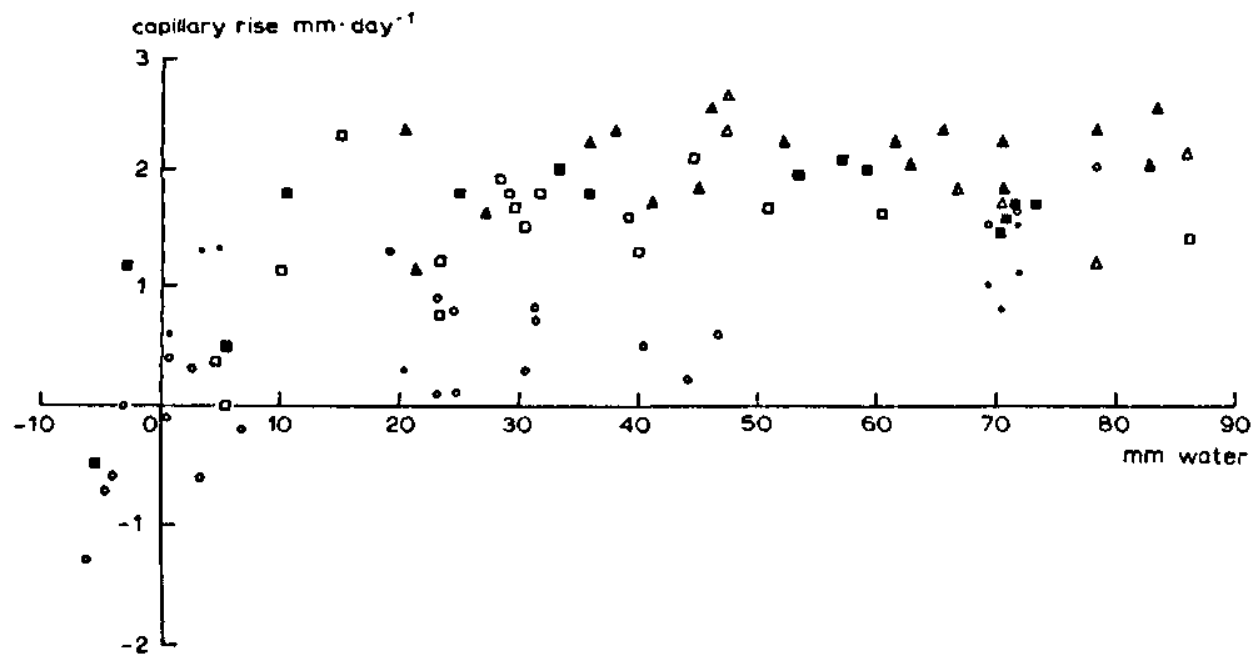

Fig. 27. Relation between capillary rise and total moisture extraction for loamy sand. Mean depth of the water table at $70 \mathrm{~cm}$. Mean values for 3 and 4 days

- $\triangle$ without precipitation; $\circ \square \triangle$ with precipitation - $E_{T}^{\text {pot }}<2 \mathrm{~mm} \cdot \mathrm{day}^{-1} ; \quad \square E_{T}^{\text {pot }} 2$ to $4 \mathrm{~mm} \cdot \mathrm{day}^{-1} ; \Delta \Delta E_{T}^{\text {pot }}>4 \mathrm{~mm} \cdot \mathrm{day}^{-1}$

capillary rise from the groundwater table averaged over periods of 3 to 4 days and the moisture conditions of the profile, expressed as a moisture deficit in relation to field capacity in loamy sand with a mean groundwater table of $70 \mathrm{~cm}$ below surface, is presented in figure 27 . It appears from these data that the capillary rise reaches nearly the observed maximum value, even when at high transpiration rates only a small deficit is present in the soil. Small values of capillary rise have been observed under conditions of a dry root zone and low values of potential transpiration. The relation between capillary rise and potential transpiration is shown in figure 28 . The variation in the data is mainly caused by the non-steady-state character of moisture extraction from the subsoil, because periods with high and low values of 
potential transpiration are alternating with each other. Further some periods with much precipitation show a strong deviation. The figures 27 and 28 agree with the calculated relation between capillary rise and suction at the underside of the root zone as presented in figure 26 , showing that the capillary rise in the loamy sand is not highly dependent on this suction value. The underside of the effective root zone is for the data presented in the figures 27 and 28 at 45 to $50 \mathrm{~cm}$ above the groundwater table when the latter is at a mean depth of $70 \mathrm{~cm}$ below the surface.

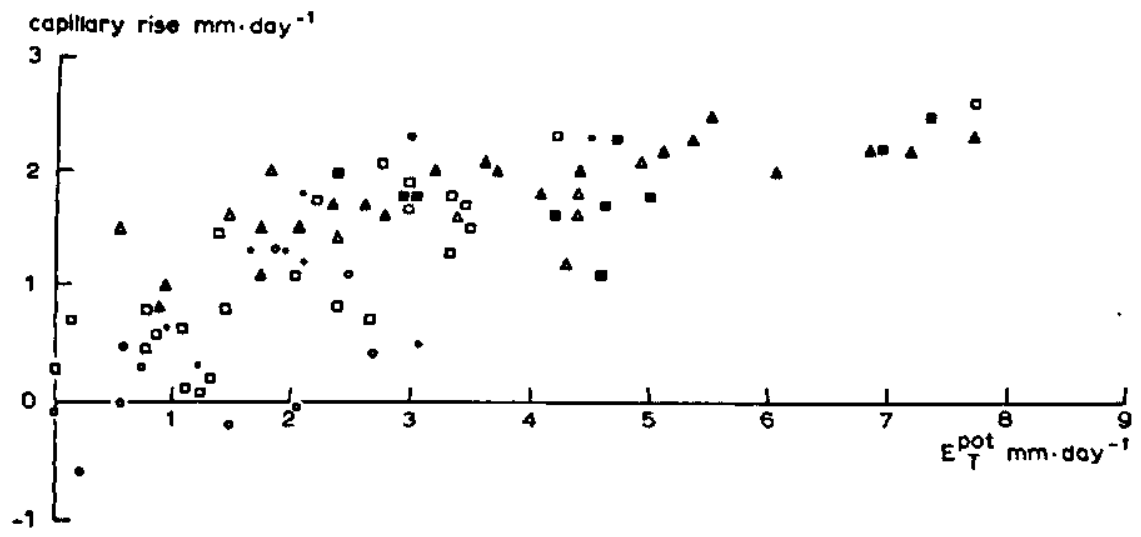

Fig. 28. Relation between capillary rise and potential transpiration for loamy sand. Mean depth of the water rable at $70 \mathrm{~cm}$. Mean values for 3 and 4 days

- $\triangle$ without precipitation; $0 \square \triangle$ with precipitation moissure extraction: $\bullet \circ$ 0-20 mm; $\square$ 20-50 mm: $\Delta \triangle>50 \mathrm{~mm}$

It is necessary, however, in investigations concerning the influence of the groundwater table on transpiration, to determine, besides capillary rise from the groundwater table, the amount of moisture which can be extracted from the soil below the effective root zone. The calculations of the amount of moisture available from this

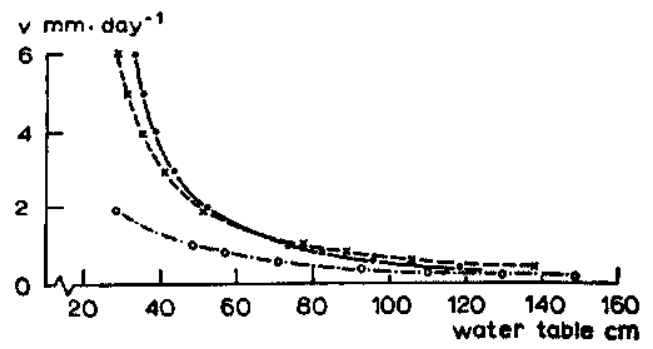

Fig. 29. Relation between the maximum capillary rise for a suction of $16000 \mathrm{~cm}$ at the underside of the effective root zone and the depth of the water table below this zone

layer are based on the steady-state solution of the capillary flow equation (41a), assuming a maximum suction of $16 \cdot 10^{3} \mathrm{~cm}$ at the underside of the effective root zone. The relation between the maximum values of capillary rise and the depth of the groundwater table is given in figure 29. The depth of the groundwater table is in this figure 
expressed in $\mathrm{cm}$ below the effective root zone. The maximum amount of moisture which can be extracted from below the effective root zone is shown in figure 30 in relation to the depth of the groundwater table. The speed with which the moisture, extracted from this layer, is available for transpiration, depends on the transpiration rate itself, which partly determines the suction gradients present below the root zone. The effect of the groundwater table on transpiration is for this reason also affected by the transpiration rate in preceding periods. In order to eliminate this effect in the calculations it seems to be useful to describe the crop reaction on water supply with the conditions present in the effective root zone, because the mean suction in this layer is also partly determined by the depth of the groundwater table and by the capillary conductivity in the layers below the root zone.

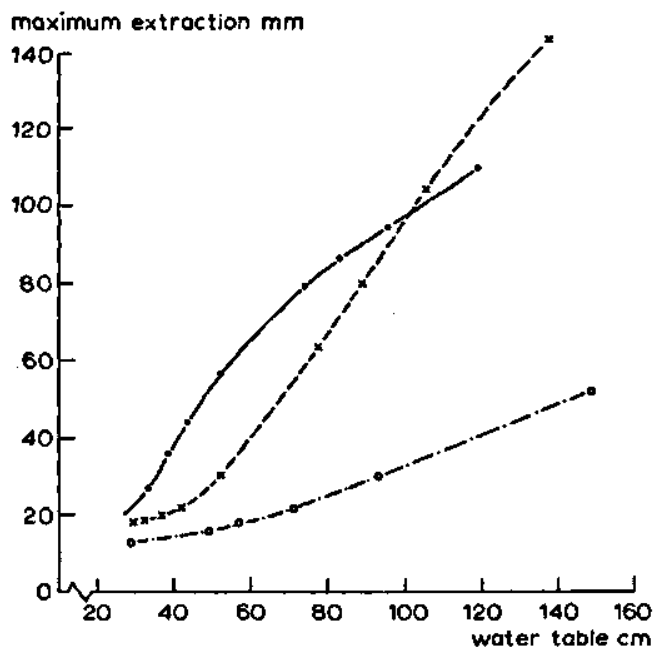

Fig. 30. Relation between the maximum amount of moisture available below the effective root zone and the depth of the water table below this zone

- loamy sand;

$x----\times$ peat

The figures 26,29 and 30 offer a possibility to characterize the drought sensitivity in relation to the depth of the groundwater table. The maximum amount of water that can be extracted by the grass within a certain number of days is calculated from these figures to which the amount of moisture available in the root zone is added. The calculations are starting from equilibrium conditions at the beginning of the period while the following propositions have been made:

a. The extraction rate of moisture present in the effective root zone is not restricted in the range between field capacity and wilting point.

b. The mean extraction rate of the moisture from below the root zone is, to a maximum amount of extraction as given in figure 30 , two times the maximum flow rate presented in figure 29.

c. The flow rate for capillary supply from the groundwater table is derived from figure 26 assuming a mean suction of $1000 \mathrm{~cm}$ at the underside of the effective root zone. 
d. The sum of moisture extraction from below the root zone and the capillary supply from the groundwater table at a certain depth of the groundwater table, has to be smaller than the corresponding value at higher groundwater tables. When the latter is not the case, the value can be obtained by graphical extrapolation.

The maximum amounts of moisture that can be extracted in relation to the depth of the groundwater table are calculated for periods of 30,60,90 and 120 days. The results of these calculations are given in table 10 .

Table 10. Maximum amounts of moisture $(\mathrm{mm})$ available for transpiration in periods of $30,60,90$ and 120 days in relation to the depth of the groundwater table

\begin{tabular}{|c|c|c|c|c|c|c|c|c|}
\hline \multirow[t]{2}{*}{ Soil } & \multirow[t]{2}{*}{$\begin{array}{l}\text { Period length } \\
\text { (days) }\end{array}$} & \multicolumn{7}{|c|}{$\begin{array}{l}\text { Depth of groundwater table } \\
\text { (cm -surface) }\end{array}$} \\
\hline & & 50 & 55 & 60 & 75 & 100 & 125 & 150 \\
\hline Sticky clay & $\begin{array}{r}30 \\
60 \\
90 \\
120\end{array}$ & $\begin{array}{l}144 \\
201 \\
258 \\
315\end{array}$ & $\begin{array}{l}- \\
- \\
-\end{array}$ & $\begin{array}{l}128 \\
167 \\
206 \\
245\end{array}$ & $\begin{array}{l}120 \\
150 \\
176 \\
203\end{array}$ & $\begin{array}{l}107 \\
124 \\
136 \\
151\end{array}$ & $\begin{array}{l}102 \\
120 \\
127 \\
137\end{array}$ & $\begin{array}{r}95 \\
111 \\
125 \\
132\end{array}$ \\
\hline Peat & $\begin{array}{r}30 \\
60 \\
90 \\
120\end{array}$ & $\begin{array}{l}- \\
- \\
-\end{array}$ & $\begin{array}{l}241 \\
388 \\
535 \\
682\end{array}$ & $\begin{array}{l}204 \\
315 \\
417 \\
528\end{array}$ & $\begin{array}{l}152 \\
212 \\
260 \\
314\end{array}$ & $\begin{array}{l}135 \\
170 \\
197 \\
219\end{array}$ & $\begin{array}{l}121 \\
161 \\
190 \\
210\end{array}$ & $\begin{array}{l}110 \\
152 \\
183 \\
205\end{array}$ \\
\hline Loamy sand & $\begin{array}{r}30 \\
60 \\
90 \\
120\end{array}$ & $\begin{array}{l}- \\
- \\
-\end{array}$ & $\begin{array}{r}355 \\
510 \\
765 \\
1020\end{array}$ & $\begin{array}{l}290 \\
448 \\
600 \\
752\end{array}$ & $\begin{array}{l}192 \\
261 \\
330 \\
399\end{array}$ & $\begin{array}{l}148 \\
195 \\
221 \\
250\end{array}$ & $\begin{array}{l}111 \\
150 \\
173 \\
201\end{array}$ & $\begin{array}{r}85 \\
110 \\
135 \\
160\end{array}$ \\
\hline
\end{tabular}

It appears from this table that the sticky clay is the most drought sensitive soil in comparison with the other soils used in this study, due to both the low values of capillary rise from the groundwater table and the small amount of moisture available from below the effective root zone. The amount of water and the extraction rate from the layers below the root zone is a measure for drought sensitivity, particularly when the groundwater table is at a great depth.

\section{Effect of soil factors on the apparent diffusion resistance of crops}

The apparent diffusion resistance $R_{c}$ of the crop has been introduced in Chapter IV.3 in order to calculate the actual transpiration. It is necessary to determine, besides the influence of light intensity, the relation between $R_{c}$ and the physical properties of the soil when soil moisture becomes a limiting factor. In relation to the interpretation of the data, the significance of $R_{c}$ has to be considered, namely that this resistance is mainly either a stomatal diffusion resistance for water vapour diffusion or a factor related to the transport resistance for liquid flow in soil and plant.

It has been assumed in the discussion presented in IV.3, that a saturated vapour pressure is present in the sub-stomatal cavities. However, the vapour pressure in the 
cavities is in equilibrium with the suction present in the leaf tissue. The following calculations are based on the considerations of a crop model with a single leaf layer, taking into account a non-saturated vapour pressure in the sub-stomatal cavities. Combination of the equations (27) and (56) expresses the transpiration as:

$$
E_{T}=\frac{e_{s}-e_{a}}{R_{a}}=\frac{e_{i n t}-e_{s}}{R_{s}}=\frac{\psi_{t}-\psi}{R_{p l}+b / k}=\frac{\varepsilon_{i n t}-e_{s}}{R_{c}}
$$

where $e_{\text {int }}$ is the actual vapour pressure in the sub-stomatal cavities and $R_{s}$ is the stomatal diffusion resistance.

The suction in the leaf tissue is related to the vapour pressure in the sub-stomatal cavities by the equation:

$$
\psi_{t}=\frac{R T^{\prime}}{\bar{V}} \ln \frac{\varepsilon_{i n t}}{e_{i n t}}
$$

where $R$ is the gas constant, $T^{\prime}$ is the temperature in degrees Kelvin and $\bar{V}$ is the volume.

The logarithmic term in this expression can be eliminated using the series expansion of the ratio $e / \varepsilon$, which can be written as:

$$
e / \varepsilon=1+(-1)^{1} \ln (\varepsilon / e)+(-1)^{2} \frac{\ln ^{2}(\varepsilon / e)}{2 !}+\ldots+(-1)^{n} \frac{\ln ^{n}(\varepsilon / e)}{n !}
$$

The neglect of all higher power terms of this series, leaving the first power term, results in a maximum deviation of $2 \%$ in the calculated value of the suction when $e / \varepsilon$ has a value between 1.0 and 0.96 , so under these conditions expression (63) can be approximated as:

$$
\ln \frac{\varepsilon_{i n t}}{e_{i n t}}=\frac{\varepsilon_{i n t}-e_{i n t}}{\varepsilon_{i n t}}
$$

Substitution of the equations (62) and (63a) in expression (61) gives:

$$
E_{T}=\frac{e_{s}-e_{a}}{R_{a}}=\frac{e_{i m t}-e_{s}}{R_{s}}=\frac{\varepsilon_{i n t}-e_{i m t}-\psi \frac{\bar{V}}{R T^{\prime}} \varepsilon_{i m t}}{\left(R_{p t}+b / k\right) \frac{\bar{V}}{R T^{\prime}} \varepsilon_{i n t}}=\frac{\varepsilon_{i m t}-e_{s}}{R_{c}}
$$

From equation (61a) follows:

$$
E_{T}=\frac{\varepsilon_{i n t}-e_{a}-\psi \frac{\nabla}{R T^{\prime}} \varepsilon_{i n t}}{R_{a}+R_{s}+\left(R_{p l}+b / k\right) \frac{\bar{V}}{R T^{\prime}} \varepsilon_{i m t}}=\frac{\varepsilon_{i m t}-e_{a}}{R_{a}+R_{c}}
$$

The relation between $R_{c}$ and the other resistances follows from this expression and 
can be written as:

$$
R_{c}=\left\{R_{s}+\left(R_{p l}+b / k\right) \frac{\bar{V}}{R T^{\prime}} \varepsilon_{i n t}\right\}\left\{\frac{\varepsilon_{i n t}-e_{a}}{\varepsilon_{i n t}-e_{a}-\psi \frac{\bar{V}}{R T^{\prime}} \varepsilon_{i n t}}\right\}+R_{a} \frac{\frac{\bar{V}}{R T^{\prime}} \varepsilon_{i n t}}{\varepsilon_{i n t}-e_{a}-\psi \frac{\bar{V}}{R T^{\prime}} \varepsilon_{i n t}}
$$

The effect of the various resistances on the value $R_{c}$ can be calculated, assuming that temporary wilting is present during the midday hours when the mean suction in the effective root zone is 16 atmospheres. Moreover, it is assumed that during this period the leaf temperature exceeds air temperature with $10^{\circ} \mathrm{C}$, while the relative humidity of the air is $80 \%$. In clear summer weather the relative humidity is during the midday hours generally lower than the assumed value used in the calculations, the assumed difference in temperature can be present, however. Based on these propositions it is possible to calculate a number of factors in equation (64). These data are given in table 11. The values in the last two columns of this table can vary somewhat, depending on the assumed propositions but they remain during midday conditions of the same order of magnitude. Equation (64) can be approximated by the following expression:

$$
R_{c} \approx 1.02 R_{s}+29.10^{-3}\left(R_{p l}+b / k\right)+0.02 R_{a}
$$

It appears from experimental investigations by GAASTRA (1959), KUIPER (1961) and SLATYER and BIERHUizen (1964), that the external resistance $R_{a}$ is about two times the stomatal resistance $R_{s}$ at maximum stomatal opening when a laminar flow is present in the external air. SLATYER and BIERHUIZEN conclude from calculations that the value of $R_{a}$ becomes considerably smaller than the corresponding value of $R_{s}$ when a turbulent flow is present in the external air, so under these conditions the stomatal resistance determines the transpiration rate. It can be concluded from these considerations that the resistance $R_{a}$ in equation (64a) is not to a considerable extent affecting the value of $R_{c}$.

The value of $R_{p t}$ is, based on the data given in table 9, assumed to be $1.04 \mathrm{~atm}$. - day $\cdot \mathrm{mm}^{-1}$, while the factor $b$ a value of $4.7 \cdot 10^{-4}$ atmospheres is given. The resistance term $\left(R_{p l}+b / k\right)$ has a value of $5.74 \mathrm{~atm} \cdot$ day $\cdot \mathrm{mm}^{-1}$, assuming that the value of the capillary conductivity is $10^{-5} \mathrm{~cm} \cdot \mathrm{day}^{-1}$ at a soil suction of 16 atmospheres. The effect of this resistance term on the value of $R_{c}$ equals under these conditions $29 \cdot 10^{-3} \cdot 5.74=0.167 \mathrm{~mm} \mathrm{Hg} \cdot$ day $\cdot \mathrm{mm}^{-1}$.

The data presented by GaAstra (1959), Kuiper (1961) and SLATYer and BierHUIZEN (1964) show that the stomatal resistance of various crops is in the order of 1 to $3 \mathrm{sec} \cdot \mathrm{cm}^{-1}$ when the stomata are fully open whereas this value increases to about $30 \mathrm{sec} \cdot \mathrm{cm}^{-1}$ when the stomata are closed.

The value of $R_{c}$ expressed in $\mathrm{mm} \mathrm{Hg} \cdot$ day $\cdot \mathrm{mm}^{-1}$ can be converted into $\mathrm{sec} \cdot \mathrm{cm}^{-1}$. A transpiration rate of $1 \mathrm{~mm} \cdot$ day $^{-1}$ has to be divided by $10 \times 24 \times 3600$ to express this value in $\mathrm{g} \cdot \mathrm{cm}^{-2} \cdot \mathrm{sec}^{-1}$ and the vapour pressure term in $\mathrm{mm} \mathrm{Hg}$ can be converted into $\mathrm{g} \cdot \mathrm{cm}^{-3}$ by multiplying by $0.623 \rho / p$, where $\rho$ has a value of $1.19 \cdot 10^{-3} \mathrm{~g} \cdot \mathrm{cm}^{-3}$ 


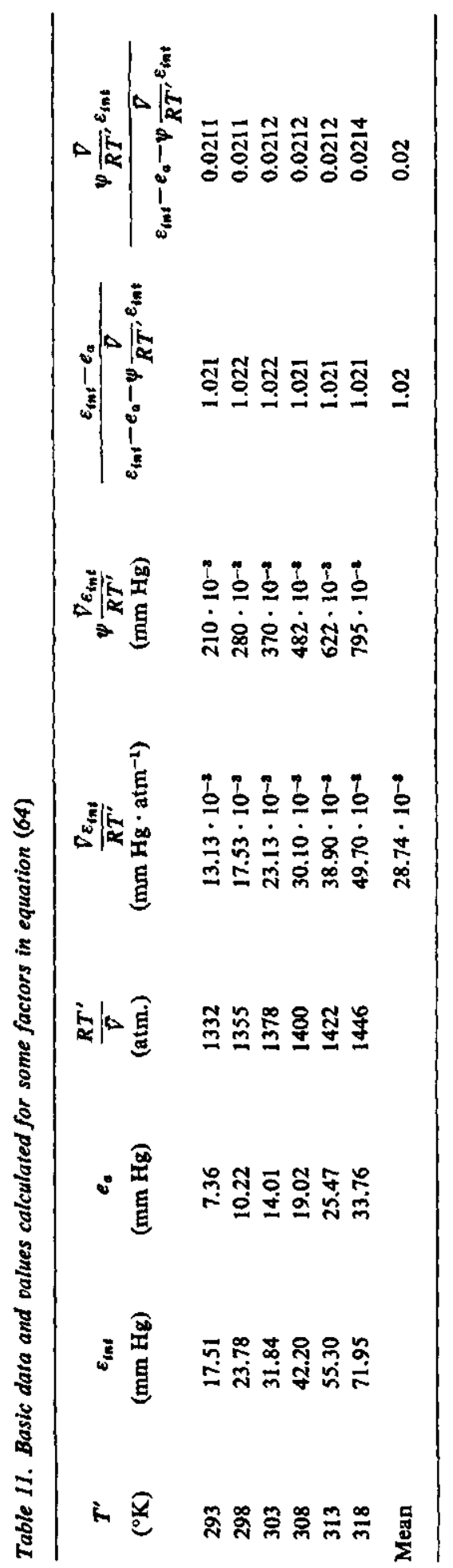


at a temperature of $20^{\circ} \mathrm{C}$ and the atmospheric air pressure $p$ is $760 \mathrm{~mm} \mathrm{Hg}$. From these conversion factors follows:

$1 \mathrm{~mm} \mathrm{Hg} \cdot$ day $\cdot \mathrm{mm}^{-1}=\frac{10 \times 24 \times 3600 \times 0.623 \times 1.19}{760 \times 10^{3}} \mathrm{sec} \cdot \mathrm{cm}^{-1}=0.94 \mathrm{sec} \cdot \mathrm{cm}^{-1}$

This conversion shows that the effect of the stomatal diffusion resistance in equation (64a) is already 6 to 18 times as large as the effect of the resistance for liquid flow when the stomata are fully open. This stomatal resistance increases considerably by stomatal closure.

It is concluded from these calculations that the value of $R_{c}$ is mainly determined by the stomatal resistance for water vapour diffusion. Although the apparent diffusion resistance $R_{c}$ of the crop is related to stomatal reaction this does not mean that both the suction in the root zone and the transport resistance for liquid flow in soil and plant are not important in controlling the value of $R_{c}$. The reaction of stomatal closure caused by a shortness of water, is related to the increase in the suction in the leaf tissue which in turn is determined by the transpiration rate, the resistances for liquid flow and the suction in the effective root zone.

The relation between $R_{c}$ and the suction in the leaf tissue can be given by the general equation:

$$
R_{c}=f\left(\psi_{l}\right)
$$

Substitution of equation (56) in (65) gives:

$$
R_{c}=f\left\{E_{T}^{r e}\left(R_{p l}+b / k\right)+\psi\right\}
$$

where $E_{T}^{r e}$ is the actual transpiration, $\psi$ and $k$ are respectively the mean values of suction and capillary conductivity in the effective root zone, while the values of $R_{p l}$ and $b$ can be obtained from the data given in table 9 .

\section{Summary}

An examination of both literature data and values calculated in the present study shows that the relation between capillary conductivity and suction can be expressed by an exponential function in the low suction range, taking into account the suction value of the air-entry point. The appearence of an apparent non-capillary pore space in some soils losing water immediately when a very small suction is present, hardly affects the considerations concerning capillary rise. The suction range in which this relation holds for the different soils varies strongly, depending possibly on the distribution and size of the soil particles. It appears from the available data that this range increases with decreasing coarseness of the soil whereas this range becomes possibly smaller again in soils with a compound structure.

The relation between capillary conductivity and suction in the range of high suctions can be expressed by a power function of the type originally proposed by 
WIND (1955). It appeared from the available data that the exponent $n$ in this equation seems to be constant, with a value of 1.4 , for various soil types. This result possibly indicates that the water transport in this range is mainly determined by a film-flow on the surface of the soil particles, whereas the flow through capillaries predominates in the low suction range.

The uptake of water from the soil by the plant roots has been described by an equation originating from GARDNER and EHLIG (1962). A calculation model has been introduced in order to calculate an estimated value for both the geometry factor of the root system and the resistance for liquid flow through the plant.

The extraction of moisture from below the effective root zone has been calculated using the steady-state solution of the flow equation. The capillary rise from the groundwater table is not highly dependent on the total moisture loss from the effective root zone when the groundwater table is relatively high, but it is affected by the exiscing transpiration rate.

The extraction rate of moisture from the soil below the effective root zone, particularly when the groundwater table is at great depth, is affected by the transpiration rate in preceding periods. The effect of the depth of the groundwater table on transpiration also depends on the preceding weather. For this reason the effect of soil moisture on transpiration is described by the conditions present in the effective root zone.

The relation between the maximum amount of moisture available for transpiration and the depth of the groundwater table has been calculated for different periodlengths. It appears from these data that the sticky clay soil is the most drought sensitive one of the soils used in the present study.

It is shown that the apparent diffusion resistance $R_{c}$ introduced in Chapter IV.3 is mainly determined by the stomatal diffusion resistance. The effect of soil conditions on the value of $R_{c}$ is described as a function of the suction in the leaf tissue, which in turn is related to the actual transpiration and to both suction and capillary conductivity in the effective root zone. 


\section{Procedure of the analysis}

A number of factors which affect evapotranspiration have been discussed in the Chapters III, IV and V. In a detailed determination of the effect of these factors it is necessary to measure evapotranspiration from a crop over short periods. Evapotranspiration is calculated from the water balance for periods of 3 and 4 days using weighable lysimeters covered with grass. The determination of the effect of the different factors on evapotranspiration proceeds from equation (34):

$$
E_{T}=E-E_{l}=\frac{\Delta\left(H_{n t} / L-E_{l}\right)+\gamma\left(E_{a}^{\prime}-E_{l}\right)}{\Delta+\gamma\left\{1+f\left(z_{0}, d\right) u R_{c}\right\}}
$$

The value of $E$ in this expression is known from the water balance, while the value of $E_{t}$ can be determined from the data of precipitation using figure 17. The value of $\Delta$ is the slope of the temperature-vapour pressure curve at air temperature at $2 \mathrm{~m}$ height and $L$ is the heat of vaporization. The term $H_{n t}$ can be calculated from equation (14):

$$
H_{m t}=(1-r) H_{s h}-{ }^{n t} H_{10}
$$

The value of $H_{s h}$ is determined from measured data of solar radiation, $r$ is the reflection coefficient of the evaporating surface, whereas ${ }^{n t} H_{c o}$ can be calculated from temperature, vapour pressure and relative duration of bright sunshine using the tables presented by Wesseling (1960). The term $E_{a}^{\prime}$ is calculated from the expression:

$$
E_{a}^{\prime}=f\left(z_{0}, d\right) u\left(\varepsilon_{a}-e_{a}\right)=\frac{13.65}{\left\{\ln \frac{200-z_{0}-d}{z_{0}}\right\}^{2}} u\left(\varepsilon_{a}-e_{a}\right)
$$

where $u$ is the wind velocity measured at 2 meter height, while $z_{0}$ and $d$ depend on crop height. $R_{c}$ is the apparent diffusion resistance of the crop and $\gamma$ is the psychrometer constant.

Applying these formulae in the calculation of evapotranspiration over short periods, the following remarks have to be made, based on the considerations presented in Chapter III.

a.1. When using the empirical relation (13) in the calculation of ${ }^{n t} H_{10}$ for short periods of 3 and 4 days, the accuracy reached is very small, since this expression only 
holds for long periods. Connected with this argument it appears that the calculated value of $H_{n t}$ can deviate considerably from the real value (MILTHORPE, 1960; TANNER and Pelton, 1960).

b.1. The neglect of the storage of heat in the soil, as is done for example in the equation proposed by Penman, can give a deviation $10 \%$ in the calculated value of $H_{n t}$ during periods of 3 and 4 days (MONTEITH, 1958).

c.l. If during long continued periods of drought the surroundings of the lysimeters have a shortness of water, resulting in a strongly reduced evapotranspiration from this area, an effect of local advection on evapotranspiration from lysimeters with a good water supply has to be taken into account. A systematic influence of local advection on evaporation from sunken pans was present in 1959, so it must be expected that the evapotranspiration from the lysimeters is affected in a similar way.

The following procedure is introduced in order to eliminate as well as possible the effects discussed in a.1, b.1 and c.l. It follows from the discussion presented in Chapter III.4 that, when using the equation proposed by Penman, the evaporation from sunken pans is very closely related to the calculated value $E_{o}$. Applying now, the combined method, discussed in III.3.1, without ignoring the storage of heat below the evaporating surface and including a term for local advection, the following expression results:

$$
(\Delta+\gamma) E_{0}=\left(1-r_{\mathrm{w}}\right) \frac{\Delta H_{s h}}{L}-\Delta\left(\frac{n t}{L} H_{l o}\right)_{\mathrm{w}}-\frac{\Delta S_{\mathrm{w}}}{L}+0.182 \gamma u\left(\varepsilon_{a}-e_{a}\right)+A_{w}
$$

where $A_{w}$ is the term giving the influence of local advection on evaporation from sunken pans. A similar relation as given in equation (35) holds for the transpiration from a crop, when both terms are taken into account. This expression can be written as:

$$
\begin{aligned}
& {\left[\Delta+\gamma\left\{1+f\left(z_{0}, d\right) u R_{c}\right\}\right] E_{T}=} \\
& \quad=\left(1-r_{c}\right) \frac{\Delta H_{s h}}{L}-\Delta\left(\frac{{ }^{n t} H_{l o}}{L}\right)-\frac{\Delta S_{c}}{L}+\gamma f\left(z_{0}, d\right) u\left(\varepsilon_{a}-e_{a}\right)-(\Delta+\gamma) E_{I}+A_{c}
\end{aligned}
$$

Combination of the equations (67) and (68) gives:

$$
\begin{aligned}
{[\Delta+\gamma\{1+f} & \left.\left.\left(z_{0}, d\right) u R_{c}\right\}\right] E_{T}= \\
& =(\Delta+\gamma) E_{o}-\left(r_{c}-r_{w}\right) \frac{\Delta H_{s h}}{L}-\Delta\left\{\frac{\left({ }^{n t} H_{l_{0}}\right)_{c}-\left({ }^{n t} H_{l_{0}}\right)_{w}}{L}\right\}-\Delta\left\{\frac{S_{c}-S_{w}}{L}\right\}+ \\
& +\gamma\left\{f\left(z_{0}, d\right)-0.182\right\} u\left(\varepsilon_{a}-e_{a}\right)-(\Delta+\gamma) E_{I}+\left(A_{c}-A_{w}\right)
\end{aligned}
$$

Considering equation (69) as the basic equation in the analysis of the data obtained from the lysimeters a further discussion concerning some terms is necessary. In connection with the arguments given in a.1, b.1 and c.1 the following remarks can be made. 
a.2. When equation (13) is applied, the same meteorological data are used in the calculation of ${ }^{n t} H_{l 0}$ from a free water surface and from a cropped surface. Differences in net longwave radiation due to differences in surface temperature are generally small during the periods of 3 and 4 days. Moreover, in the calculations of ${ }^{n t} H_{l o}$ from equation (13) equality of surface temperature and air temperature is assumed. This means that in the basic equation (69) the term $\left({ }^{n t} H_{l o}\right)_{c}-\left({ }^{n t} H_{l o}\right)_{w}$ can be considered as being equal to zero.

b.2. The absorption of solar radiation in free water is related to the depth in dependence of the cleanliness of the water. For this reason and due to the relatively high value of the heat capacity the storage of heat in water is in general greater than the corresponding value in a soil below a grass cover. However, it is unlikely that the storage of heat in shallow sunken evaporation pans considerably exceeds the corresponding value below a surface covered with grass. This means that the value of the term $\left(S_{c}-S_{w}\right)$ in equation (69) is much smaller than the value of $S_{c}$. Since $S_{c}$ has already a relatively small influence on evapotranspiration when using periods of 3 and 4 days, the term $\left(S_{c}-S_{w}\right)$ will be neglected.

c.2. The influence of local advection is among other things dependent on the dimensions and the roughness of the evaporating surface. The significance of this advective term increases when the dimensions of the evaporating surface decrease and the surface roughness increases. The surface area of the evaporation pan is approximately $20 \%$ of the corresponding area of the lysimeters, but the surface roughness of the latter is higher than the corresponding value of the pan. Although the influence of local advection is not the same for both surfaces, the effect of $\left(A_{c}-A_{w}\right)$ on evapotranspiration is considerably smaller than the corresponding influence of $A_{c}$. It is assumed that the effect of the term $\left(A_{c}-A_{w}\right)$ on evapotranspiration can be ignored in the calculations performed. A further discussion on this proposition is given in Chapter VI.3.

The relation used in the analysis of the evapotranspiration data obtained from the lysimeters does not contain the factors discussed, so equation (69) can be written as:

$$
\begin{aligned}
& {\left[\Delta+\gamma\left\{1+f\left(z_{0}, d\right) u R_{c}\right\}\right] E_{T}=} \\
& \quad=(\Delta+\gamma) E_{o}-\left(r_{c}-r_{w}\right) \Delta H_{s h} / L+\gamma\left\{f\left(z_{0}, d\right)-0.182\right\} u\left(\varepsilon_{a}-e_{a}\right)-(\Delta+\gamma) E_{I}
\end{aligned}
$$

In this equation is $E_{T}$ the transpiration from the crop, calculated from the water balance equation and from the interception based on the arguments given in Chapter IV.4, while $E_{o}$ is the evaporation from a free water surface, measured with sunken pans.

The unknown factors in equation (69a) are:

1. The mean reflection coefficient $r_{c}$ of the crop. In $\left(r_{c}-r_{w}\right)$ for the mean value of the reflection coefficient $r_{w}$ of a free water surface, the generally accepted value of 0.05 is taken. 
2. The surface roughness $z_{0}$ and the zero-plane displacement $d$ of the crop. From the discussion given in Chapter JII.1 follows that both factors depend on the height of the crop as well as on the wind velocity. In the term $f\left(z_{0}, d\right)$ the effect of the surface roughness and of the zero-plane displacement is taken into account. A separation of both terms is not possible since no measurements of the vertical profile of wind velocities are available. Moreover, no conclusions can be given concerning the validity of the logarithmic wind function under unstable atmospheric conditions. 3. The apparent diffusion resistance $R_{c}$ of the crop. It appeared from the discussion given in Chapter IV.3 that this factor, under conditions of optimum water supply only depends on the type of the crop, on light intensity and possibly on temperature and aeration, while it was shown in the discussion given in Chapter V.4 that this factor must also be related to the suction in the leaf tissue, which in turn depends on the suction in the root zone, on capillary conductivity and on the transport resistance in the plant, when a shortness of moisture is present in the soil.

The determination of these factors in relation to the variables mentioned, is performed by a reiterative operation of the data. A first estimate of the values of two of the unknown factors in relation to the given variables is made in this operation. Using equation $(69 \mathrm{a})$ the values of the third unknown factor can be calculated and are then analysed in their relation to the variables on which the factor depends. In this way a first estimate of this third factor is obtained. Next, from the first estimates of the first and third factor, the values of the second factor can be calculated using again equation (69a). These values are further analysed in relation to the variables on which this factor depends, resulting in a second estimate of this factor. The operation with equation (69a) is continued as long as the curves giving the relations concerned, are changing.

When calculating the mean reflection coefficient $r_{c}$ of the crop, equation $(69 \mathrm{a})$ is written as:

$$
\begin{array}{r}
\left(r_{c}-0.05\right) \Delta H_{s h} / L=(\Delta+\gamma)\left\{E_{o}-\left(E_{T}+E_{I}\right)\right\}-\gamma f\left(z_{0}, d\right) u R_{c} E_{T}-0.182 \gamma u\left(\varepsilon_{a}-e_{a}\right)+ \\
+\gamma f\left(z_{0}, d\right) u\left(\varepsilon_{a}-e_{a}\right)=F
\end{array}
$$

When the values of $\Delta H_{s h} / L$ are plotted against the calculated values of $F$, a linear relationship will have to be found, in which the line is passing through the points as well as through the origin. The slope of this line gives the mean value of $\left(r_{c}-0.05\right)$. As a first estimate of the mean reflection coefficient of grass, a value of 0.20 is introduced, based on the investigations reported by SCHOLTE UBING (1959).

In determining $f\left(z_{0}, d\right)$ equation (69a) is expressed as:

$$
f\left(z_{0}, d\right)=\frac{(\Delta+\gamma)\left\{E_{T}+E_{I}-E_{o}\right\}+\left(r_{c}-0.05\right) \Delta H_{s h} / L+0.182 \gamma u\left(\varepsilon_{a}-e_{a}\right)}{\gamma\left\{\left(\varepsilon_{a}-e_{a}\right)-R_{c} E_{T}\right\} u}
$$

The values of $f\left(z_{0}, d\right)$ calculated from $(69 \mathrm{c})$ are analysed in their relation to crop height and wind velocity. Only those data have been used in which the denominator of the right term of the equation exceeds 0.75 . The influence of errors in the basic 
data on the calculated values of $f\left(z_{0}, d\right)$ increases considerably when the value of the denominator becomes smaller. Only a few data concerning values of $z_{0}$ and $d$ are available from literature. As a first estimate of $f\left(z_{0}, d\right)$ the data given in table 3 are used, assuming that the zero-plane displacement equals zero, while for other grass lengths the values have been interpolated between the values given.

When calculating the values of the apparent diffusion resistance $R_{c}$, equation (69a) is written as follows:

$$
R_{c}=\frac{(\Delta+\gamma)\left\{E_{T}+E_{I}-E_{o}\right\}+\left(r_{c}-0.0 S\right) \Delta H_{s h} / L+0.182 \gamma u\left(\varepsilon_{a}-e_{a}\right)-\gamma f\left(z_{0}, d\right) u\left(\varepsilon_{a}-e_{a}\right)}{-\gamma f\left(z_{0}, d\right) u E_{T}}
$$

Since in this equation the influence of errors in the basic data becomes also predominant when the denominator of the right hand term of this equation is too small, data with a denominator smaller than 0.75 are not taken into consideration in the analysis. Based on the arguments given in Chapter IV.3 a first estimate of $R_{c}$ under conditions of optimum water supply and high light intensity can be given a value equal to zero. A first estimate of $R_{c}$ is not possible for other conditions.

Since only a few periods were present in which both low light intensity and a shortness of water are determining the value of $R_{c}$, a study concerning the interrelationship of both factors in their effect on $R_{c}$, is not possible in the present study. For this reason it is assumed that under these conditions the effect of both factors can be expressed as:

$$
R_{c}=R_{c}^{l}+R_{c}^{\psi}
$$

where $R_{c}^{l}$ is the factor depending on light intensity and $R_{c}^{\psi}$ the factor giving the effect of the suction in the leaf tissue on the value of $R_{c}$.

The procedure started with the determination of $R_{c}$ from equation (69d) using first estimates of $r_{c}$ and $f\left(z_{0}, d\right)$.

2. Determination of the unknown factors under conditions of optimum water supply

The factors $r_{c}, f\left(z_{0}, d\right)$ and the relation of $R_{c}^{l}$ to light intensity and to temperature are determined under conditions of optimum water supply. In this analysis, data are used from lysimeters in which the capillary rise from the groundwater table was about 80 to $90 \%$ of the evapotranspiration and in which the total extraction of moisture from the profile did not exceed $20 \mathrm{~mm}$. The effect of the suction in the effective root zone, of the capillary conductivity and of the transport resistance in the plant on the value of $R_{c}^{\psi}$, is determined afterwards with equation (69d), taking the other factors into account as known quantities.

When determining the values of the apparent diffusion resistance $R_{c}^{l}$, the mean reflection coefficient $r_{c}$ and the roughness function $f\left(z_{0}, d\right)$ in this analysis, balance periods with one of the following properties are not taken into consideration: 
a. Periods in which the presence of local advection could be shown by comparing calculated evaporation from a free water surface and measured evaporation from sunken pans.

b. Periods in which the grass on the lysimeters was cut resulting in a discontinuity of crop height.

c. Periods in which the daily values of precipitation exceeded $15 \mathrm{~mm}$ giving in a number of periods unaccountable values of both pan evaporation and evapotranspiration from the lysimeters.

d. Periods in which the calculated amount of interception exceeded evapotranspiration, or in which during the last day of the period much precipitation was present, resulting in a calculated amount of interception that was nearly equal to the value of evapotranspiration and it was unlikely that this amount of interception also evaporated during that last day.

In the discussion on the results obtained from this analysis only those figures are given that result from the last operation performed in the reiterative procedure.

\subsection{Reflection coefficient}

The relation of $\Delta H_{s h} / L$ and the calculated values of $F$, the right hand term of equation (69b), is presented in figure 31 . The value of the slope is 0.18 , so with an

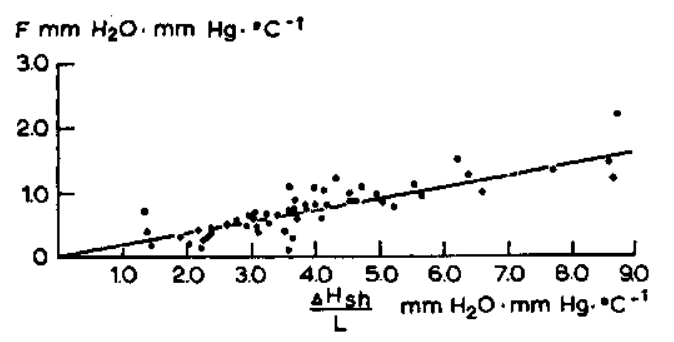

Fig. 31. The relation between calculated values of the right hand term $(F)$ of equation (69b) and $\Delta H_{s} / L$

assumed value of $r_{w}$ of 0.05 the mean reflection coefficient of the grass cover is 0.23 . The value of the reflection coefficient determined in this analysis, agrees better with the data given by MoNTEITH (1959) as discussed in Chapter III.2.2, than with the values given by ScHOLTE UbING (1959).

\subsection{Roughness function}

The effect of wind on the roughness function $f\left(z_{0}, d\right)$ gives an increase in roughness at low wind velocities due to the flutter of the grass leaves. At high wind velocities, however, the leaves adapt positions parallel to the direction of flow which results in a streamlining effect making the surface aerodynamically more smooth. The in- 
fluence of the wind velocity is likely to be higher for tall than for short grass. Moreover, under conditions of strong incoming radiation and low wind velocities, atmospheric instability affects the roughness function too. It is not possible, because of the remaining variation in the data, to give in the present study an analysis of the effect of wind velocity in its interrelationship with crop height, so it is assumed that the combined effect of both factors can be expressed as:

$$
f\left(z_{0}, d\right)=g(l) \cdot h(u)
$$

where $g(l)$ is a function of crop height with the same dimensions as $f\left(z_{0}, d\right)$ and $h(u)$ is a dimensionless factor which depends on wind velocity. In equation (71) the absolute values of $g(l)$ and $h(u)$ depend on each other. It is assumed that $h(u)$ equals unity at a mean wind velocity of $1.75 \mathrm{~m} \cdot \mathrm{sec}^{-1}$ at 2 meter height.

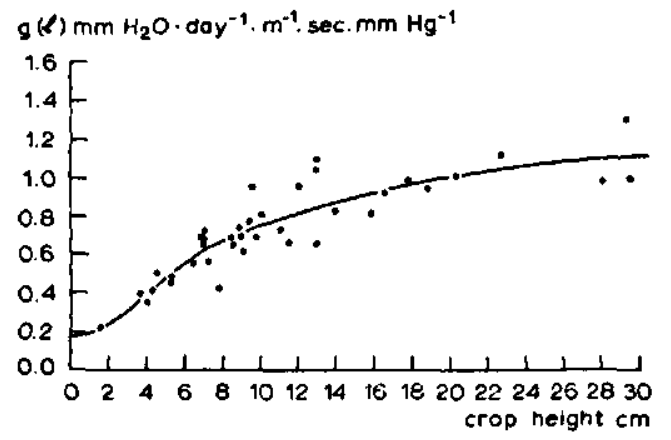

Fig. 32. The relation between $g(l)$ and crop height for a mean wind velocity at $2 \mathrm{~m}$ height of $1.75 \mathrm{~m} \cdot \mathrm{sec}^{-1}$

The values of $f\left(z_{0}, d\right)$ are calculated with equation (69c) and are related to crop height, which results in a curve giving the relation of $g(l)$ to grass length. The ratio of the calculated values of $f\left(z_{0}, d\right)$ and $g(l)$ is related to wind velocity, giving the relationship between $h(u)$ and $u$.

The relation between grass length and $g(l)$ is presented in figure 32 , for data reduced to a mean wind velocity of $1.75 \mathrm{~m} \cdot \mathrm{sec}^{-1}$ at a height of 2 meter. The calculated values of $h(u)$ are presented in figure 33a in relation to the mean wind
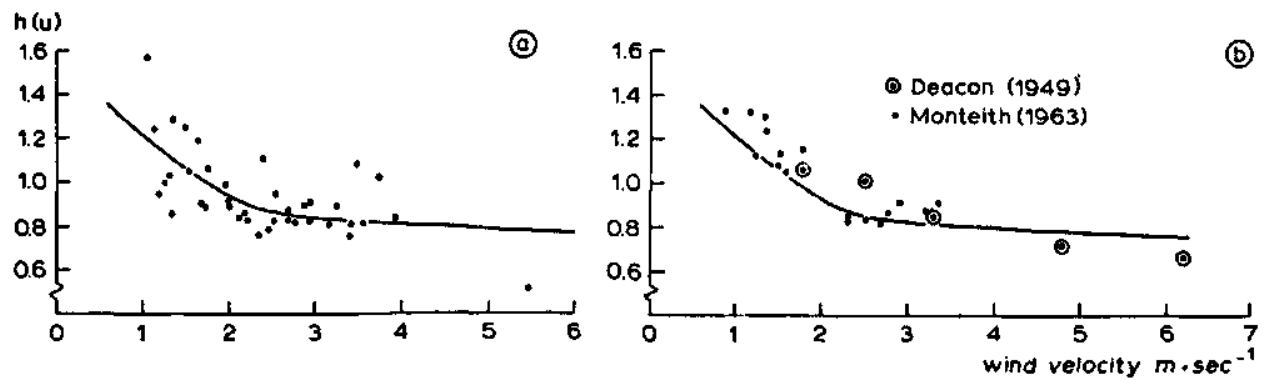

Fig. 33. The relation between $h(u)$ and wind velocity at $2 m$ height. a. data obtained from the analysis; b. calculated from data given by DeACON (1949) and by MONTEITH (1963). The curve originates from fig. $33 a$ 
velocity at 2 meter height. From data published by DEACON (1949) concerning grass with a height from 60 to $70 \mathrm{~cm}$ with a zero-plane displacement of $25 \mathrm{~cm}$ and from data given by MONTEITH (1963) of grass with a crop height of $75 \mathrm{~cm}$ and a displacement of the zero-plane of $45 \mathrm{~cm}$ values of $h(u)$ are calculated for different wind velocities. The results of these calculations are presented in figure $33 \mathrm{~b}$, in which the curve drawn is taken from figure 33a. In spite of the difference in the height of the grass, the adaptation of the curve to the calculated values agrees reasonably well. The value of $g(l)$ at a grass height of $75 \mathrm{~cm}$ calculated from these data, is equal to 1.43 .

\subsection{Apparent diffusion resistance of grass with optimum water supply}

The relation between the apparent diffusion resistance $R_{c}^{t}$ and light intensity is presented in figure 34 . The resistance reaches its minimum value, equal to zero, at a mean light intensity of $0.38 \mathrm{cal} \cdot \mathrm{cm}^{-2} \cdot \mathrm{min}^{-1}$. This minimum value agrees with the discussion on this subject given in Chapter IV.3. With decreasing light intensities

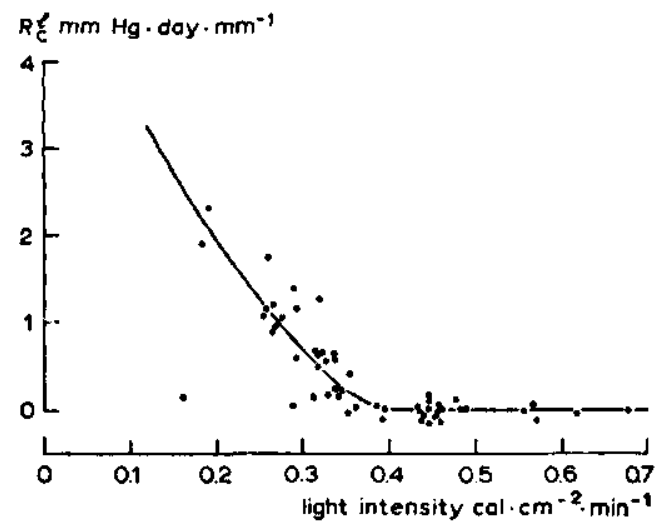

Fig. 34. The relation between the apparent diffusion resistance of grass $\left(R_{\varepsilon}^{l}\right)$ and mean light intensity

an increase in resistance is present in a similar way as is shown in the discussion on the physiological investigations given in Chapter IV.2.1. The results of this analysis show that the mean light intensity during periods of 3 and 4 days can be considered as a measure for the factor controlling stomatal opening.

No relation could be found in the analysis between the apparent diffusion resistance and temperature. In general an influence of low temperatures on stomatal opening coincides with low values of light intensity during that part of the day, so it is not possible to give a decision, based on the present data, on the existence of a relation between stomatal opening and temperature.

An effect of aeration on the value of the apparent diffusion resistance could not be shown, mainly because of the fact that the highest groundwater tables present in these experiments are at $50 \mathrm{~cm}$ below the surface resulting in a sufficient aeration for the shallow root zone of the grass. 
Balance periods in which the presence of local advection was shown were left out of consideration in the analysis given in VI.2 so the relations determined are not affected by dry conditions in the surroundings of the lysimeters. Particularly during the dry summer of 1959 extreme conditions concerning the effect of the water supply on evapotranspiration prevailed. This regards the high values of potential evapotranspiration in summer as well as the low ones under dry conditions of the soil in autumn. In order to determine the effect of a restricted supply of water on evapotranspiration under these conditions, it is necessary to calculate a value of potential evapotranspiration governed by the micro-climate present at the lysimeters.

It has been assumed in Chapter VI.1 that the difference in the effects of local advection on respectively evaporation from the pans and evapotranspiration from the lysimeters can be ignored. However, before applying this proposition in the analysis, a further testing is necessary. The course of the measured pan evaporation and
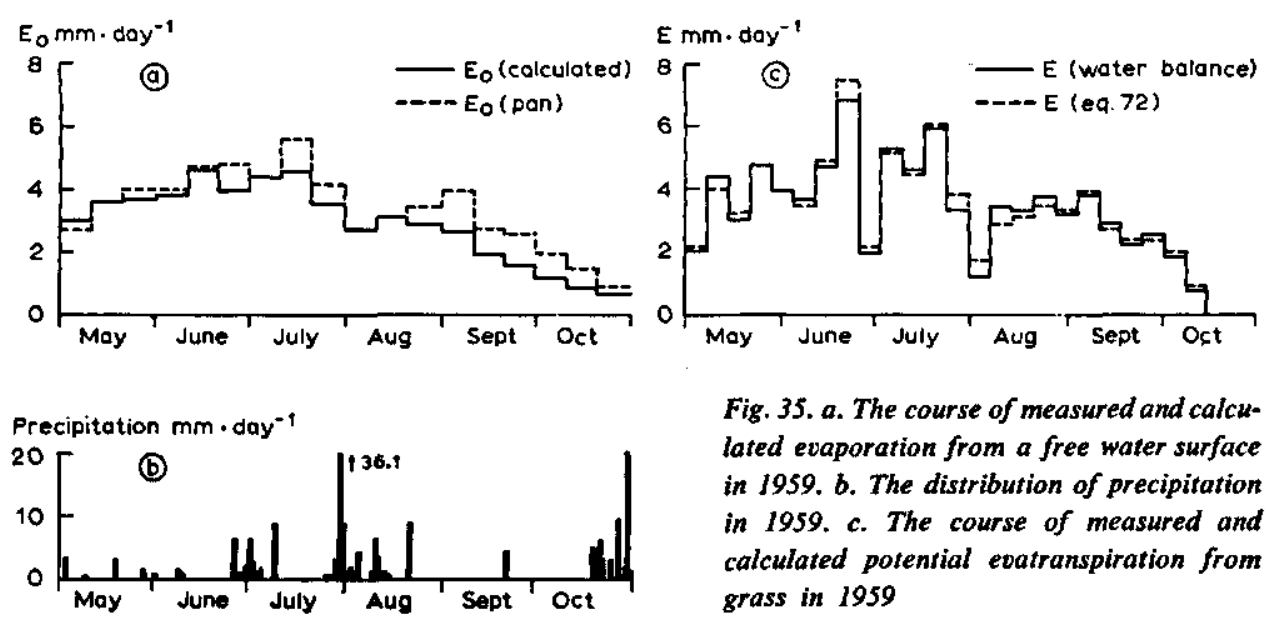

Fig. 35. a. The course of measured and calculated evaporation from a free water surface in 1959. b. The distribution of precipitation in 1959. $c$. The course of measured and calculated potential evatranspiration from grass in 1959

of the calculated evaporation during the summer half year of 1959 is presented in - figure 35a (see also figure 13). In May and during the first twenty days of June the differences between both values are very small because of the fact that no limiting conditions were present in the water supply of the surroundings. The difference between calculated and measured evaporation is also small during periods in which much precipitation was present just before or during the time considered (figure 35b). For the other periods the measured data of evaporation are systematically higher than the calculated ones, in particular during the long continued period of drought in the latter part of the summer and in early autumn. The systematic deviation is related to the restricted water supply in the direct surroundings of the lysimeters, resulting in a strongly reduced evapotranspiration from this area. 
In order to test the proposition assumed, the potential evapotranspiration from grass under optimum conditions of water supply is calculated for weekly periods using the following expression:

$$
E=\frac{(\Delta+\gamma) E_{o}-0.18 \Delta H_{s h} / L+\gamma\left\{f\left(z_{0}, d\right)-0.182\right\} u\left(\varepsilon_{a}-e_{a}\right)+\gamma f\left(z_{0}, d\right) u R_{c}^{l} E_{I}}{\Delta+\gamma\left\{1+f\left(z_{0}, d\right) u R_{c}^{l}\right\}}
$$

In these calculations the values of $f\left(z_{0}, d\right)$ and $R_{c}^{l}$ obtained from the relations given in VI.2 are used, while as value of $E_{o}$ the measured value of the sunken pans is taken. The values of evapotranspiration calculated from equation (72) are compared with the corresponding values determined from the water balance of lysimeters with a good water supply, in which the extraction of soil moisture from the profile did not exceed $20 \mathrm{~mm}$ except during one period in June. The data obtained from both methods are presented in figure 35c. The difference between both values is very small and a systematic deviation cannot be proved. The difference between both values added over the season is equal to $11 \mathrm{~mm}$. Based on these results it cannot be proved that the proposition assumed in relation to local advection is incorrect under the given conditions of the experiments, so this argument can be used in the present study in the analysis of the data.

4. Effect of the water supply in the effective root zone on evapotranspiration

The presence of a too small water supply to the roots in comparison to the potential transpiration of the crop results in an increase of the apparent diffusion resistance $R_{c}^{\psi}$ that is related to the increase in suction in the leaf tissue. In the discussion given in Chapter V.4 on the relation between the suction in the leaf tissue and the apparent diffusion resistance, the following expression was derived:

$$
R_{c}^{\psi}=f\left\{E_{T}^{r e}\left(R_{p l}+b / k\right)+\psi\right\}
$$

Where $E_{T}^{r e}$ is the real transpiration from the crop, $R_{p l}$ and $b$ are dependent on the type of the crop and represent respectively the resistance for water transport in the plant and the geometry of the root system, while $\psi$ and $k$ give the mean suction in the effective root zone and the capillary conductivity related to it.

In the analysis of the data obtained from the lysimeters the right hand term of this equation can be calculated, since $E_{T}^{r e}$ is known from the water balance minus the amount of interception calculated from figure 17 for the period considered, values of $R_{p t}$ and $b$ can be obtained from table 9 , while the mean suction in the effective root zone is derived from the data obtained from the measurements with nylon units and values of $k$ can be taken from figure 22 in relation to the mean suction.

However, in many hydrological investigations the value of $E_{r}^{r e}$ is often unknown, so it appears to be useful to relate for practical purposes $R_{c}$ to an other parameter also depending on both climatological and soil physical factors. For this reason the 
concept of the potential suction in the leaf tissue is introduced; it is defined as the theoretical suction necessary in the leaf tissue to ensure potential transpiration at the soil physical conditions prevailing in the effective root zone of the crop. This theoretical suction value can be calculated, analogous to equation (56) given in Chapter V.2.1, from the following expression:

$$
\psi_{l}^{p o t}=E_{T}^{p o t}\left(R_{p l}+b / k\right)+\psi
$$

where $E_{T}^{\text {pot }}$ is the potential transpiration calculated with equation (34), taking into account the values of $R_{c}^{l}$ as presented in figure 34, while the other factors have the same meaning as is given for equation (65a).

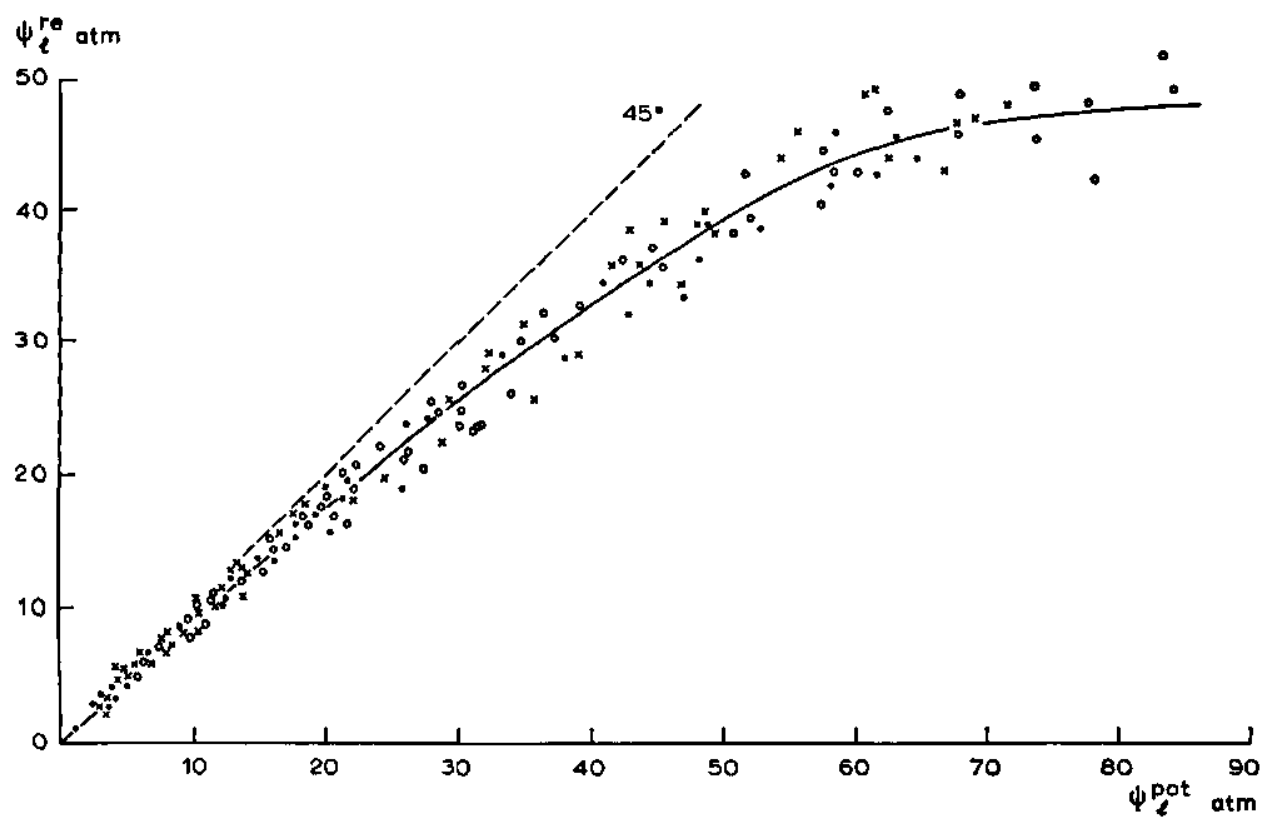

Fig. 36. The relation between the calculated values of the real $\left(\psi_{1}^{\prime *}\right)$ and the potential $\left(\varphi_{1}^{\text {pot }}\right)$ suction in the leaf tissue. The data are calculated for grass on loamy sand ( $\bullet)$, sticky cluy (o) and peat (x)

A comparison between the values of $\psi_{i}^{\text {pot }}$ and $\psi_{t}^{\text {re }}$, calculated with the given equations is presented in figure 36 . The scatter of the data around the curve is particularly at low suctions small due to the fact that both equations only differ in the transpiration term. Moreover, the curve shows that the real suction in the leaf tissue reaches as mean value for periods of some days its maximum at a value from 48 to 50 atmosphere. The maximum values of the soil suction measured in the upper part of the effective root zone were approximately 57 atmosphere. SLATYER (1957) reported maximum values of the suction in the leaf tissue of tomato, privet and cotton equal to 41,70 and 77 atmosphere respectively. These data concern measurements performed at sunrise. The values of the suction in the soil of the root zone measured at the same day are 45, 110 and 107 atmosphere respectively. The data of the maximum suction 
in the leaf tissue of grass, obtained from the calculations performed, appear to be acceptable.

The relationship between $\psi_{i}^{r e}$ and $\psi_{i}^{\text {pot }}$ as presented in fig. 36 , shows that the relation given in equation (65a) can be changed into:

$$
R_{c}^{\psi}=g\left(\psi_{t}^{p o t}\right)=g\left\{E_{T}^{p o t}\left(R_{p l}+b / k\right)+\psi\right\}
$$

The relation between $R_{c}^{\psi}$ (eq. 69d) and $\psi_{i}^{\text {pot }}$ (eq. 73), presented in figure 37, is calculated from data obtained from the three soils used in the present study.

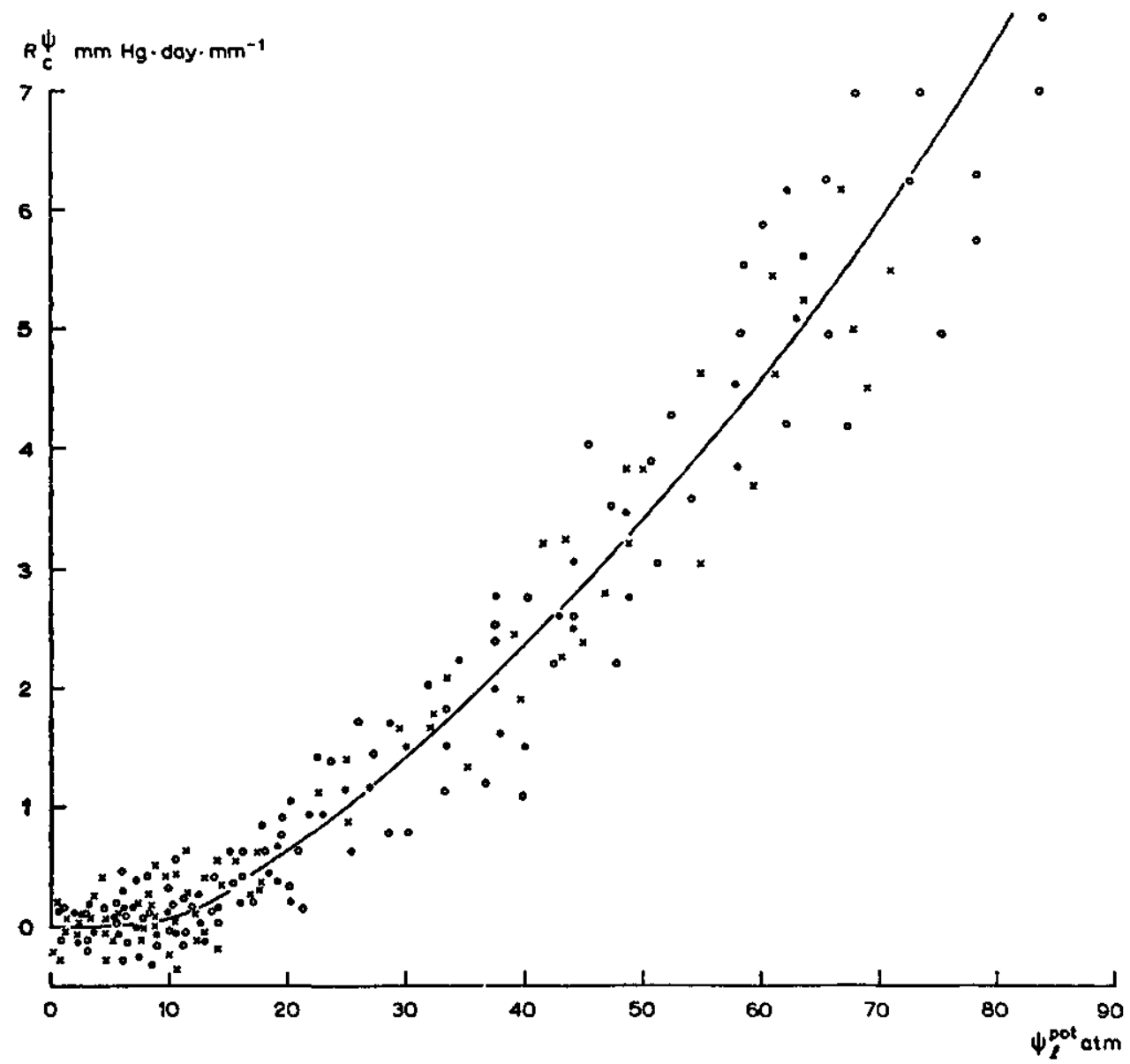

Fig. 37. The relation befween $R_{c}^{\downarrow}$ and the potential suction in the leaf tissue $\left(\psi_{l}^{\text {pot }}\right)$. The dafa are calculated for grass on loamy sand ( () , sticky clay (o) and peat $(x)$

The relation between real transpiration and potential transpiration can be derived from equation (34) and is written as:

$$
E_{T}^{r e}=\frac{\Delta+\gamma\left\{1+f\left(z_{0}, d\right) u R_{c}^{l}\right\}}{\Delta+\gamma\left\{1+f\left(z_{0}, d\right) u\left(R_{c}^{l}+R_{c}^{\psi}\right)\right\}} E_{T}^{p o t}
$$


It appears from this expression that the influence of the suction on the reduction of transpiration, at a given value of both potential transpiration and suction in the root zone, also depends on temperature, on wind velocity, on light intensity and on the roughness function of the crop. The reduction in transpiration due to a shortness of water increases with increasing surface roughness and increasing wind velocity, whereas it decreases with increasing temperature.

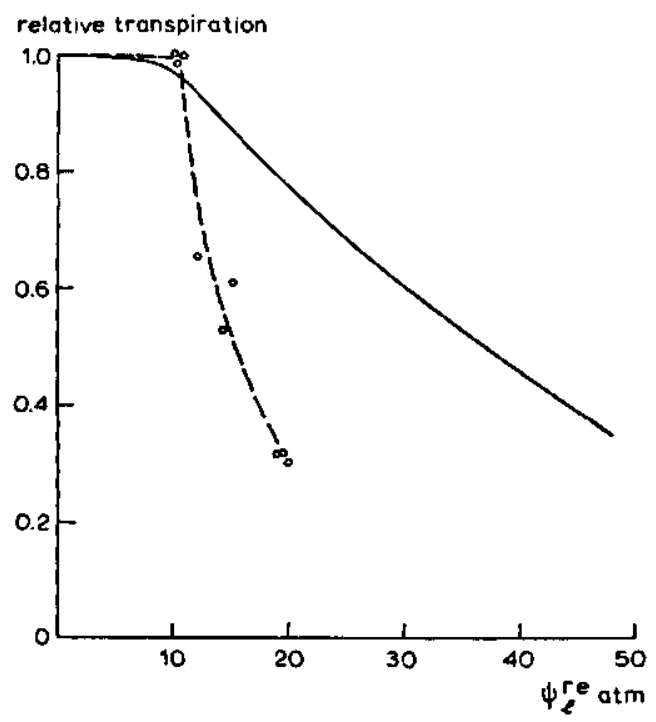

Fig. 38. The relation between the relative transpiration and the real suction in the leaf tissue ०---० Birdsfoot trefoil (EHLIG and GARDNER, 1964)

Grass

The relation between the relative transpiration from grass and the calculated value of $\psi_{l}^{\text {re }}$ is presented in figure 38 for a temperature of $20^{\circ} \mathrm{C}$ and assumed values of $f\left(z_{0}, d\right) u$ and $R_{c}^{l}$ equal to respectively unity and zero. This figure also presents data concerning Birdsfoot Trefoil given by EHLIG and GARDNER (1964). A strong deviation exists between both curves, which can be explained, aside from a possible influence due to the differences in the crops used, by the following arguments:

a. The measurements taken by Ehlig and Gardner concern a crop with a uniform root distribution in shallow containers, whereas the calculations performed in the present study are related to the mean suction in the effective root zone of a crop with a non-uniform root distribution in relation to depth, which can result in a high suction in the leaf tissue when low suctions are still present in the soil of the lower part of the effective root zone, giving an increased extraction from this layer.

b. The measurements of the suction in the leaf tissue in the experiments reported by Ehlig and Gardner were performed between 8.00 and 9.00 a.m. The mean value of the suction in the leaf tissue, however, exceeds considerably their measured values, since this suction is more or less in phase with the daily cycle of transpiration. The values in the leaf tissue calculated for the grass are mean values for periods of some days. 
c. A strong deviation can exist between the value of $f\left(z_{0}, d\right) u$ taken in the present calculations and the corresponding value under the experimental conditions of Ehlig and Gardner.

In order to get an expression of a similar type as those presented by VISSER (1963, 1964 ) equation (75), assuming that $R_{c}^{t}$ equals zero, is rewritten as:

$$
\left\{E_{T}^{p o t}-E_{T}^{r e}\right\}\left[f\left\{E_{T}^{r e}\left(R_{p l}+b / k\right)+\psi\right\}\right]^{-1}=\frac{\gamma}{\Delta+\gamma}\left\{f\left(z_{0}, d\right) u\right\} E_{T}^{r e}
$$

The relation of the effect of the availability of soil moisture on actual evapotranspiration, as proposed by Visser, can be expressed either in terms of the suction in the soil or in terms of the soil moisture content. For a comparison of the relation derived in the present study with the expressions given by Visser, the relation expressed in the suction of the soil moisture is used. This relation of Visser is given by the following equation:

$$
\left(g E_{0}-E\right)^{n-1}\left(\frac{C}{\psi^{n-1}}-E\right)=D
$$

where $g$ is an empirically determined crop constant, $n$ is the exponent originating from the relation between capillary conductivity and suction, $C$ and $D$ are also constants to be determined by experiment. Visser assumes that the value of $n$ is equal to 2 for the majority of soils.

A comparison of both equations shows that (75a) has a more complicated structure than the relation given by Visser. The main differences in both relations can be explained by the following arguments:

a. Visser assumes in his approach that the transport resistance in the plant from the root surface to the atmosphere is a constant, whereas it has been shown in Chapter V.4 that stomatal closure is the main factor reducing transpiration. Moreover, it was shown that the stomatal resistance varies from fully open to closed by a factor exceeding 10.

b. Visser does not consider the effects of crop development and stomatal resistance in relation to the distribution of net energy over sensible heat transfer and evapotranspiration.

It are mainly these factors which prevent the relations proposed by Visser from being of general application in the calculation of actual evapotranspiration during periods of a few days under widely different climatological conditions.

The relation between real transpiration, potential transpiration and the mean suction in the effective root zone is presented in figure 39 for the three soils used in the present study. These relations are calculated for an air temperature of $20^{\circ} \mathrm{C}$, while $f\left(z_{0}, d\right) u$ and $R_{c}^{l}$ have assumed values of respectively unity and zero. This figure shows that the reduction in transpiration at a given value of both potential transpiration and mean suction, highly depends on the capillary conductivity of the soils used. 

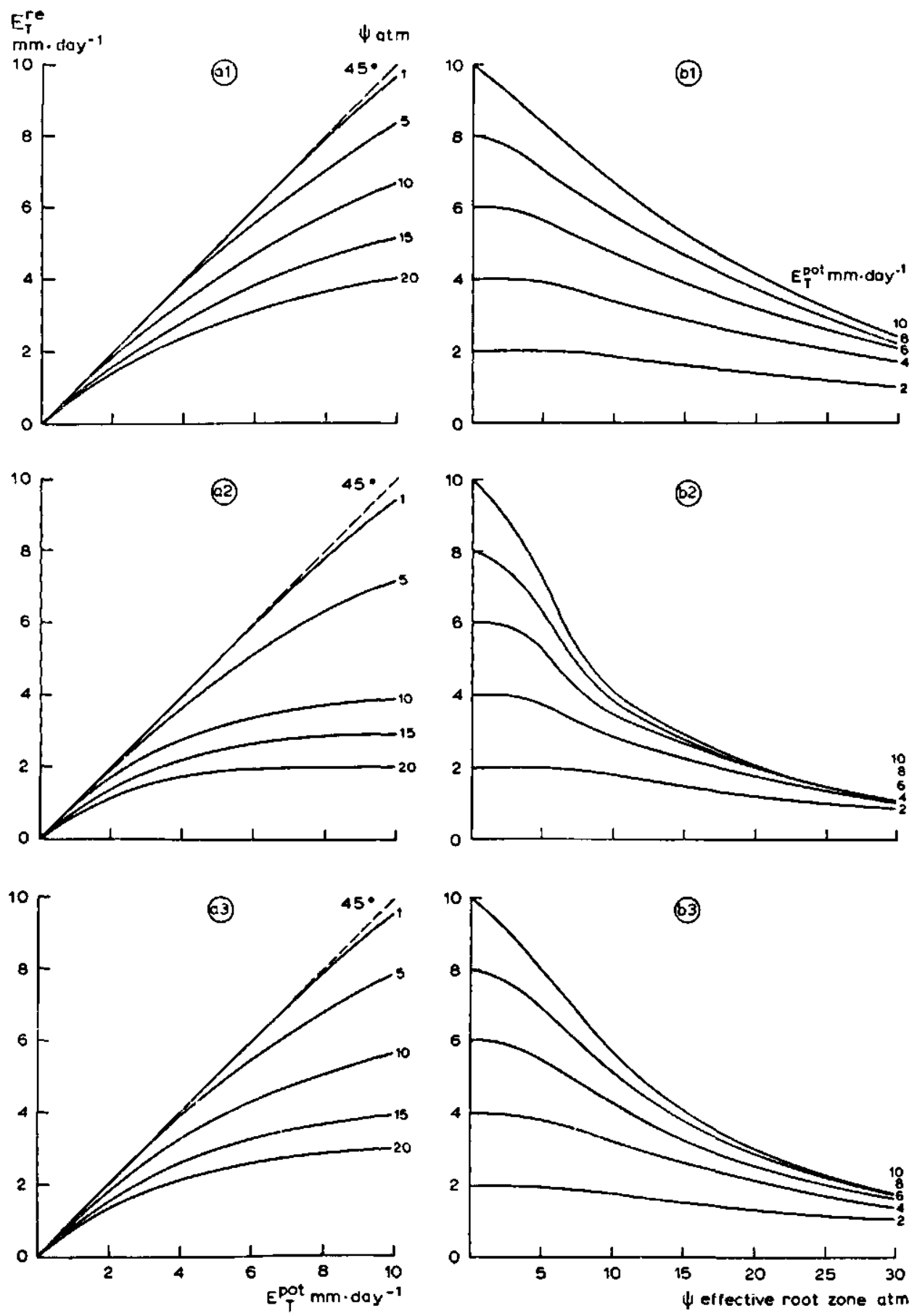

Fig. 39. a. The relation between real transpiration and potential transpiration for various values of the suction in the effective root zone. 1 . loamy sand; 2 . sticky clay; 3. peat. 6 . The relation between real transpiration and mean suction in the effective root zone for various values of potential transpiration. 1. loamy sand; 2. sticky clay; 3. peat 


\section{Calculation of crop factors in relation to evaporation}

Calculated values of potential evapotranspiration are compared with data determined from the water balance of lysimeters with an optimum water supply. The relation between calculated evapotranspiration, according to $E=f \cdot E_{0}$, and measured data is presented in figure 40. In these calculations it is assumed that $f$ has a value of 0.8 . The deviation between calculated and measured potential evapotranspiration becomes larger with increasing values of evapotranspiration. Moreover, the scatter of the points increases due to the difference in crop height between the various periods.

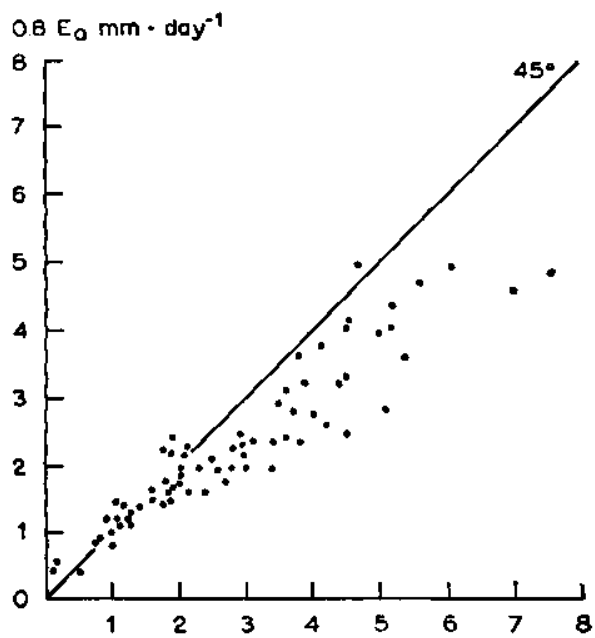

Fig. 40. The relation between measured potential evatranspiration from grass and the reduced values of evaporation from a free water surface

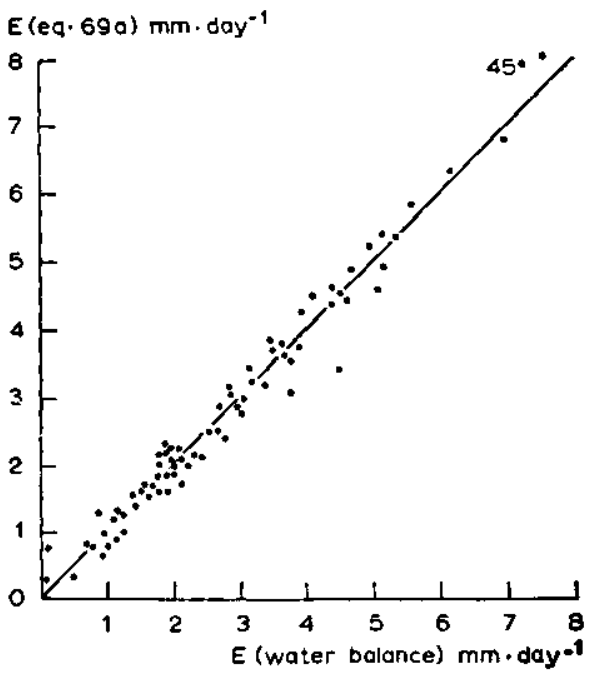

Fig. 41. The relation between measured potential evatranspiration from grass and the values calculated with equation (69a)

Potential evapotranspiration is calculated with equation (69a) taking into account the values of $R_{c}^{l}$ derived from figure 34. The results of these calculations, presented in figure 41 , show a good agreement with the data obtained from the lysimeters. The balance periods used in this figure do not coincide with the balance periods used in the reiterative procedure.

Often, data of evaporation from a free water surface are used in the calculation of potential evapotranspiration from crops. These data are then multiplied by an experimentally determined factor for a certain crop in order to calculate the evapotranspiration. A reasonable relation appears to exist between pan evaporation and potential evapotranspiration from crops when this relation is determined for mean monthly values (STANHILL, 1961; TALSMA, 1963). Difficulties arise, however, when transfering these relations from one area to an other climatologically widely different one.

The development of a general applicable method for the calculation of the relation 
between the evaporation from a free water surface, either calculated with the Penman equation or measured from sunken pans, and the potential evapotranspiration from a crop is of value, since it offers possibilities to calculate the crop factors for widely different climates.

In calculating the relation between evaporation from a free water surface and potential evapotranspiration from a crop, it is assumed that $R_{\mathfrak{c}}^{l}$ is equal to zero, while the considerations start from the following equations:

$$
\begin{gathered}
E=f \cdot E_{o} \\
E=E_{o}-0.18 \frac{\Delta}{\Delta+\gamma} \frac{H_{s h}}{L}+\frac{\gamma}{\Delta+\gamma}\left\{f\left(z_{0}, d\right)-0.182\right\} u\left(\varepsilon_{a}-e_{a}\right)
\end{gathered}
$$

It appears from a comparison of the equations that the value of the crop factor depends on the correlation between $E_{o}$ and both $\Delta\left(H_{s h} / L\right)(\Delta+\gamma)^{-1}$ and $\gamma u\left(\varepsilon_{a}-e_{a}\right)$. $\cdot(\Delta+\gamma)^{-1}$, while this factor also depends on the roughness of the evaporating surface.
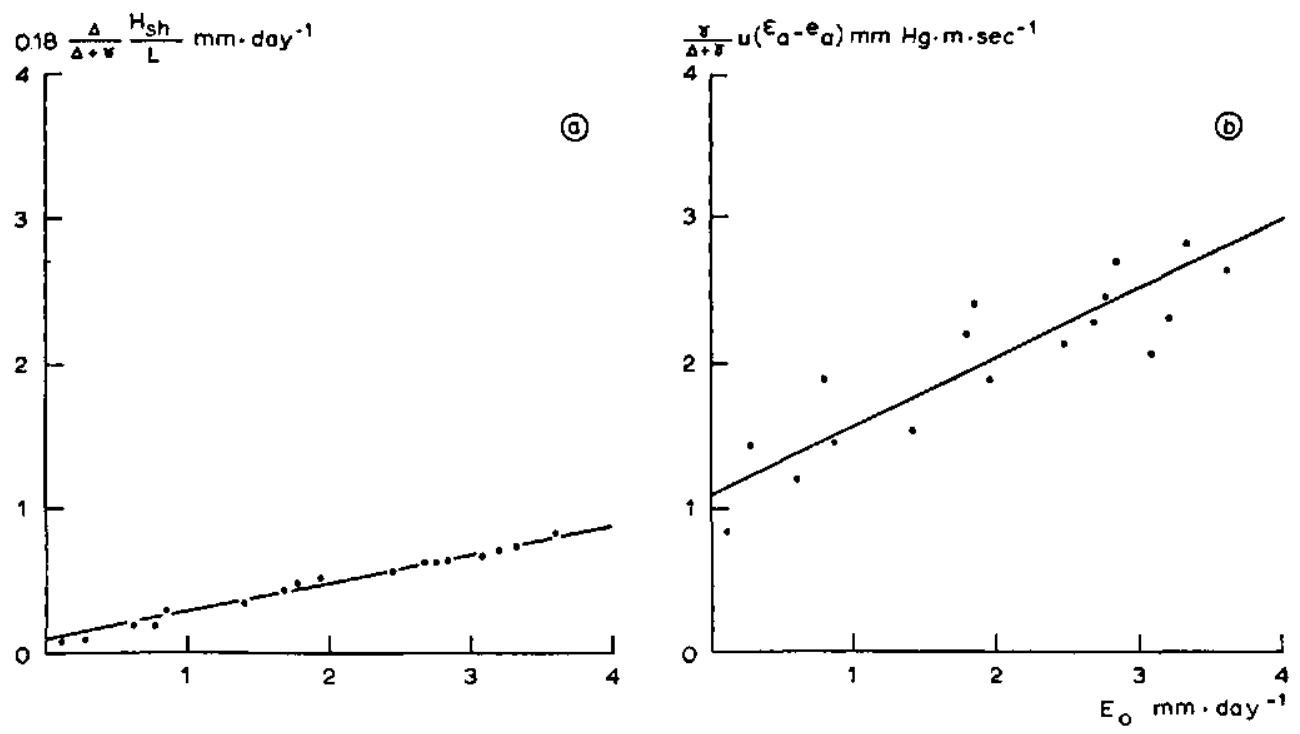

Fig. 42. a. The relation between $0.18(\Delta /(\Delta+\gamma)) H_{\mathrm{on}} / L$ and $E_{0}$ for climatological conditions in the Netherlands; $b$. The relation between $(\gamma /(\Delta+\gamma)) u\left(\varepsilon_{a}-e_{a}\right)$ and $E_{o}$ for climatological conditions in the Netherlands

The mean values of $f\left(z_{0}, d\right)$ for crops like grass and alfalfa, are for monthly periods more or less constant due to the frequency of mowing. Moreover, the correlation between $E_{o}$ and the meteorological factors mentioned, is rather high for the mean monthly values as is shown by MAKKINK (1960) for the climatological conditions prevailing in the Netherlands. The relation between $E_{o}$ and respectively $0.18 \Delta\left(H_{s h} / L\right)$. $\cdot(\Delta+\gamma)^{-1}$ and $\gamma u\left(\varepsilon_{a}-e_{a}\right)(\Delta+\gamma)^{-1}$ for mean monthly values in the Netherlands are presented in figure 42 . The relations can be given by the expressions: 


$$
0.18 \frac{\Delta}{\Delta+\gamma} \frac{H_{s h}}{L}=0.20 E_{o}+0.09
$$

and

$$
\frac{\gamma}{\Delta+\gamma} u\left(\varepsilon_{a}-e_{a}\right)=0.48 E_{o}+1.08
$$

Substitution of these expressions in equation (79) gives:

$$
E=\left\{0.71+0.48 f\left(z_{0}, d\right)\right\} E_{o}+\left\{1.08 f\left(z_{0}, d\right)-0.29\right\}
$$

If the mean values of $f\left(z_{0}, d\right)$ remain constant during the course of the year, a linear relationship exists between evaporation and evapotranspiration. The relation between evapotranspiration and evaporation is composed of a number of linear relationships when $f\left(z_{0}, d\right)$ varies over the year.

These considerations are also applied in the determination of the relation between evapotranspiration from alfalfa and evaporation from a free water surface (calculated with the Penman equation in which the modified wind function for a sunken pan is used) based on data from experiments performed by VAN 'T LEVEN and HADDAD $(1963,1964 a, 1964 b)$ in the Medjerda Valley in Tunesia.

The height of the crop varied during the summer period from 5 to $50 \mathrm{~cm}$ with a frequency of mowing of once in 4 weeks. The growth was considerably less during the winter season, so the crop was cut once in 8 to 10 weeks, giving a considerably smaller yield than during the summer months. For this reason it is assumed in the present calculations that the mean crop height was equal to $25 \mathrm{~cm}$ over the summer season, whereas a mean height of $15 \mathrm{~cm}$ was taken for the winter season. Moreover, it was assumed that $f\left(z_{0}, d\right)$ for alfalfa can also be calculated from the relations given in VI.2.2.

The relation between the calculated values of $E_{a}$ and respectively $0.18 \Delta\left(H_{s h} / L\right)$. $\cdot(\Delta+\gamma)^{-1}$ and $\gamma u\left(\varepsilon_{a}-e_{a}\right)(\Delta+\gamma)^{-1}$ are presented in figure 43 for the mean monthly values in Tunesia. The relations can be given by the expressions:

$$
0.18 \frac{\Delta}{\Delta+\gamma} \frac{H_{s h}}{L}=0.193 E_{o}+0.15
$$

and

$$
\frac{\gamma}{\Delta+\gamma} u\left(\varepsilon_{a}-e_{a}\right)=0.80 E_{o}+1.15
$$

Substitution of both relations in equation (79) gives:

$$
E=\left\{0.66+0.80 f\left(z_{0}, d\right)\right\} E_{0}+\left\{1.15 f\left(z_{0}, d\right)-0.36\right\}
$$

The mean wind velocity during the two years of observation was $2.9 \mathrm{~m} \cdot \mathrm{sec}^{-1}$, so $f\left(z_{0}, d\right)$ derived from the figures 32 and 33 , has respectively for mean crop heights of 25 and $15 \mathrm{~cm}$ a value of 0.92 and 0.76 . These values are used in equation (79b), giving the following expressions for the relation between the evapotranspiration 
from alfalfa and calculated evaporation from a free water surface in Tunesia:

Summer season (May to September): $E=1.40 E_{o}+0.70$

Winter season (October to April): $E=1.27 E_{o}+0.51$

The mean values of $E_{0}$ in the summer and winter period are respectively 5.63 and $2.04 \mathrm{~mm} \cdot$ day $^{-1}$. With the relations (84) and (85) the mean values of potential evapotranspiration in both seasons are calculated, giving values of respectively 8.57 and
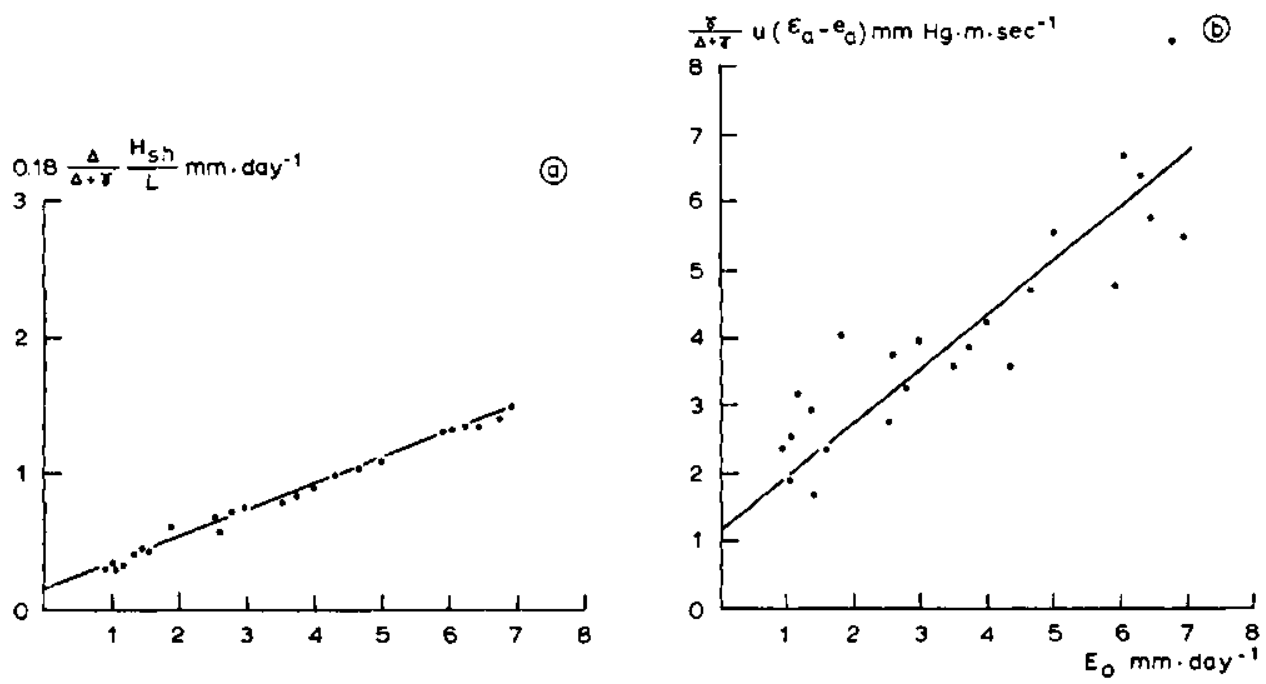

Fig. 43. a. The relation between $0.18(\Delta /(\Delta+\gamma)) H_{\mathrm{san}} / L$ and $E_{0}$ for the climatological conditions in Tunesia b. The relation between $(\gamma /(\Delta+\gamma)) u\left(\varepsilon_{a}-e_{0}\right)$ and $E_{0}$ for the climatological conditions in Tunesia

$3.10 \mathrm{~mm} \cdot \mathrm{day}^{-1}$. The calculated mean values are connected by a linear relationship given by the following equation:

$$
E=1.52 E_{o}+0.02
$$

This expression gives the apparent relation between the potential evapotranspiration from alfalfa and evaporation from a free water surface for the conditions prevailing in Tunesia. A comparison of the calculated relation with the observed data is presented in figure 44 . The remaining variation between the calculated line and the observations is mainly caused by the scatter of the points presented in figure 43 as well as by the uncertainties in the estimates of $f\left(z_{0}, d\right)$. A comparison of the potential evapotranspiration from alfalfa, calculated directly with equation (79) without using the linear relationships given in figure 43 , with the values determined from the water balance of the lysimeters is presented in figure 45 . This figure shows a better agreement between calculated and measured evapotranspiration than the relation given in figure 44 , since the monthly deviation from the linear relationships presented in figure $\mathbf{4 3}$ is taken into account. 
However, for many crops the value of the roughness function is unknown, whereas the apparent relation between potential evapotranspiration and evaporation is known for various crops under different climatological conditions. The considerations given in the preceding discussion can also be used in the determination of a rough estimate of $f\left(z_{0}, d\right)$ by back solution for different crops from the apparent relation between evapotranspiration and evaporation, provided that the relations as presented in the figures 42 and 43 are known. These rough estimates can be used in their turn in the calculation of the relation between evapotranspiration and evaporation for regions with other climatological conditions. This procedure might be of particular value for the calculation of potential evapotranspiration from crops when designing irrigation projects under any given climatological condition.

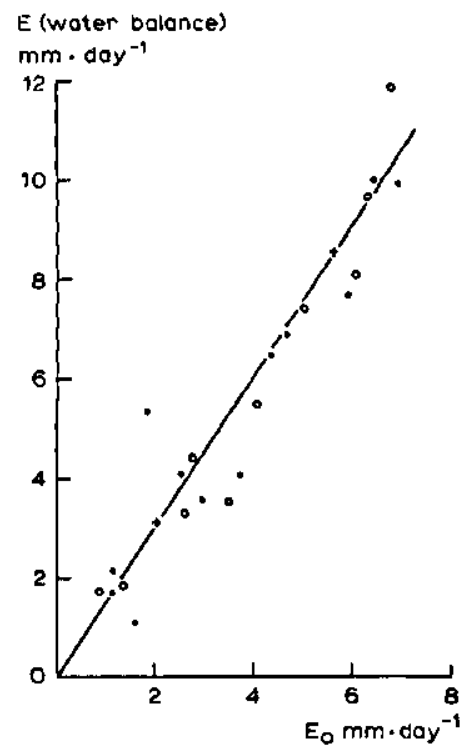

Fig. 44. The relation between the measured potential evapotranspiration from alfalfa and the calculated evaporation from a free water surface for the climatological conditions prevailing in Tunesia. The line is calculated with equation (86)

- 1962; - 1963; + mean values for summer and winter season

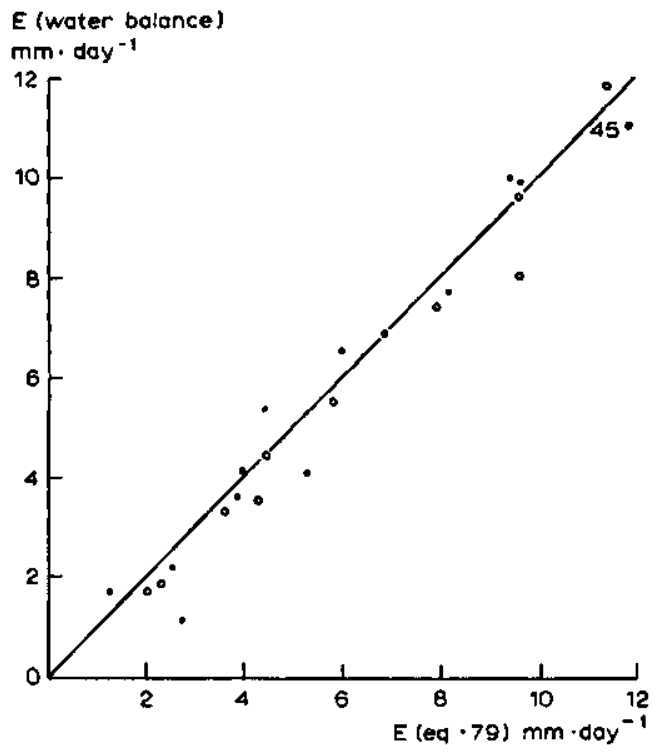

Fig. 45. The relation between the measured potential evapotranspiration from alfalfa and the values calculated with equation (79) for the climatological conditions in Tunesia

○ 1962; 1963

\section{Summary}

A description is given of the procedure used in the analysis of data obtained from lysimeters concerning the evapotranspiration from grass. The relations holding for evapotranspiration from grass and for evaporation from sunken pans are combined in order to eliminate the uncertainties arising from the errors in the calculated values 
of net longwave radiation over short periods, from the neglect of the storage of heat in the soil and from the effect of local advection.

The mean reflection coefficient of the grass cover and the influence of light intensity on the apparent diffusion resistance of the crop, as well as the relation between the roughness of the evaporating surface and both the crop height and the wind velocity are determined under conditions of optimum water supply for periods in which no local advection was present.

It is shown that a difference in the influence of local advection on potential evapotranspiration and on pan evaporation cannot be proved under the conditions prevailing in the experiments performed.

The influence of water supply on the value of the apparent diffusion resistance is described in relation to potential transpiration, to the suction and capillary conductivity in the effective root zone, to the geometry of the root system and to the resistance for transport of water through the plant.

It is shown that the reduction in transpiration, besides on the value of the apparent diffusion resistance of the crop also depends on temperature, on wind velocity and on the roughness of the evaporating surface. The reduction in transpiration increases, at a given value of the apparent diffusion resistance in relation to a shortness of water, with increasing surface roughness and increasing wind velocity, whereas the reduction decreases with increasing temperatures.

It appeared to be possible to calculate the relation between potential evapotranspiration and evaporation from a free water surface, the latter either calculated with the Penman equation or measured from sunken pans. These calculations are performed for the determination of the apparent relation between potential evapotranspiration from alfalfa and calculated evaporation under the climatological conditions prevailing in Tunesia. This procedure may be of particular value for the calculation of potential evapotranspiration from various crops when designing irrigation projects under any given climatological condition. 
This study gives an analysis of the main factors determining the actual evapotranspiration from crops in their interrelationships with each other. Actual evapotranspiration can be calculated from a combined aerodynamic and energy balance approach, taking into account the following factors:

a. The reflection coefficient of the crop.

b. The surface roughness of the crop in relation to crop height and to wind velocity.

c. The physiological properties of the crop with special reference to the resistance for liquid through the plant and to the stomatal diffusion resistance.

d. The suction in the effective root zone and the capillary conductivity of the soil in relation to this suction.

The introduction of an apparent diffusion resistance of the crop was necessary due to the geometry of the evaporating surface. The relation of this factor to light intensity and to the suction in the leaf tissue has been determined for grass.

It is shown that the amount of precipitation intercepted by the crop increases evapotranspiration when the apparent diffusion resistance of the crop is not equal to zero. A separation between transpiration and evaporation of intercepted precipitation is introduced in order to determine the effects of other factors on transpiration.

A full discussion is presented on the relation between capillary conductivity and suction from both data obtained from literature and those calculated in this study. Some indications are present that this relation in the range of low suctions is governed by flow through filled capillaries, whereas in the range of high suctions it is mainly determined by film-flow on the surface of the soil particles.

An estimate of the resistance for liquid flow through the plant as well as a value for the geometry and the activity of the root system are calculated from a flow model. These estimates offered the possibility to calculate the effect of the suction and the capillary conductivity in the effective root zone on the suction in the leaf tissue, which in turn affects the value of the apparent diffusion resistance of the crop.

An equation has been derived in which the effects of the factors determining the evapotranspiration are taken into account. It is shown that the reduction in transpiration due to a shortness of water, also depends, at given soil physical conditions in the effective root zone, on temperature, wind velocity and the roughness of the evaporating surface.

A discussion is given on the possibility to calculate the relation between potential evapotranspiration from crops and evaporation from a free water surface. The method 
has been applied to the calculation of the relation between potential evapotranspiration from alfalfa and calculated values of the evaporation from a free water surface under the climatological conditions prevailing in Tunesia.

The transfer of this type of relations from one area to an other climatologically different one is discussed. This procedure may be of value for the calculation of potential evapotranspiration from various crops when irrigation projects have to be designed under any given climatological condition. 


\section{Samenvatting}

Deze studie geeft een analyse van de voornaamste factoren, die de werkelijke evapotranspiratie van gewassen bepalen. Deze belangrijkste factoren kunnen als volgt worden weergegeven:

a. de afvoer van waterdamp uit de luchtlagen dicht bij het verdampend oppervlak naar de hoger gelegen lagen;

b. de hoeveelheid energie beschikbaar voor de verdamping van water;

c. de opening van de huidmondjes en de diffusie van waterdamp van de intercellulaire holten naar de externe atmosfeer;

d. de aanvoersnelheid van water naar het verdampend oppervlak.

Elk van deze factoren kan als beperkende factor voor de verdamping optreden, zodat alle genoemde factoren in het onderzoek zijn betrokken. Op grond van dit onderzoek is een formulering gegeven voor de berekening van de werkelijke evapotranspiratie onder verschillende klimatologische omstandigheden.

In hoofdstuk II wordt een overzicht gegeven van de apparatuur en van de waarnemingsmethoden die bij dit onderzoek zijn gebruikt.

Voor de neerslaggegevens werd gebruik gemaakt van de op maaiveldhoogte gemeten hoeveelheden. Dit in verband met de systematische afwijking, die onder invloed van de windsnelheid optreedt, van de waarden die op $40 \mathrm{~cm}$ standaardhoogte werden gemeten.

De gemeten waarden van de evaporatie uit twee ingegraven verdampingspannen vertoonden geen systematische afwijkingen ondanks de verschillen in opstelling. Dit geeft een aanwijzing dat de rails van de weegwagen en het dak van de waarnemingskelder van de lysimeters geen overwegende invloed hebben op de verdamping uit deze pannen.

De lysimeters bevatten ongestoorde bodemprofielen. De bij dit onderzoek gebruikte gronden zijn knipklei (12 lysimeters) uit de omgeving van Sneek, veen (12 lysimeters) uit de omgeving van Kamerik (Utrecht) en leemhoudend zand (8 lysimeters) uit de omgeving van Wageningen.

De verandering van vochtinhoud van het profiel in de lysimeters werd naast de periodiek uitgevoerde wegingen ook bepaald met behulp van nylon elementen. Beide methoden gaven alleen vergelijkbare resultaten indien geen hysteresiseffecten aanwezig waren. 
In Hoofdstuk III zijn de meteorologische factoren besproken die de evapotranspiratie van een gewas bepalen.

Het waterdamptransport van het verdampend oppervlak naar hoger gelegen luchtlagen wordt beheerst door de dampspanningsgradiënt, de turbulentie van de luchtstroom en de ruwheid van het verdampend oppervak.

De verticale verdeling van de windsnelheid kan onder neutrale omstandigheden van de atmosfeer met een logaritmische functie van de hoogte worden beschreven. Bij andere atmosferische omstandigheden geeft een machtsfunctie van de hoogte een beter resultaat. Het geeft echter grote moeilijkheden om de exponent van deze functie met enige nauwkeurigheid uit experimentele gegevens te bepalen. De fout die door het gebruik van de logaritmische functie onder niet neutrale omstandigheden wordt geïntroduceerd, is in de orde van grootte van 10 tot $15 \%$ wanneer dicht bij het verdampend oppervlak wordt gemeten. De ruwheid van het verdampend oppervlak is afhankelijk van de gewashoogte en van de windsnelheid.

De evapotranspiratie kan ook worden berekend uit de energiebalans. De nauwkeurigheid van de berekende netto straling is niet groot, wanneer gebruik wordt gemaakt van empirische relaties. Een fout van 10 tot $20 \%$ in de berekende waarde van de netto straling moet worden verwacht bij een periodelengte van enkele dagen.

De warmteberging in de grond is voor perioden van enkele dagen ongeveer $10 \%$ van de netto straling. De warmteoverdracht naar de grond in de lysimeters blijkt, tengevolge van de opstelling van de bakken, groter te zijn dan de overdracht onder normale veldomstandigheden.

De verdeling van de netto energie tussen verdamping en warmtetransport naar de atmosfeer kan tot stand worden gebracht door middel van de Bowen-verhouding, waarvoor de over de tijd gemiddelde waarden van de temperatuur- en dampspanningsgradiënten noodzakelijk zijn. Ten einde de metingen van deze gradiënten te vermijden zijn methoden ontwikkeld die een combinatie van de aerodynamische en de energie balans methoden zijn. Het biijkt bij deze gecombineerde methoden echter noodzakelijk te zijn om de eigenschappen van het verdampend oppervlak in rekening te brengen.

De gemeten panverdamping en de berekende verdamping van een vrij wateroppervlak vertonen goede overeenstemming indien ingegraven pannen worden gebruikt. De boven de grond opgestelde verdampingspannen geven, tengevolge van deze opstelling, systematisch te hoge verdampingswaarden.

In de literatuur zijn aanwijzingen aanwezig, dat de gecombineerde methoden ook onder omstandigheden met advectie op grote schaal bevredigende resultaten geven. De lokale advectie op kleine schaal kan de evapotranspiratie uit lysimeters sterk beïnvloeden. Het is echter bijzonder moeilijk om een schatting te maken van de invloed van de lokale advectie op de evapotranspiratie. Er zijn enige aanwijzingen in de literatuur, dat deze lokale effecten reeds over een zeer korte afstand worden geëlimineerd. Een systematische invloed van de lokale advectie kon onder de gegeven proefomstandigheden alleen in de zeer droge zomer van 1959 worden aangetoond. 
In Hoofdstuk IV wordt de invloed van enige plantenfysiologische aspecten behandeld.

De vochtopname door de plant wordt veroorzaakt door de transpiratie. De vochtstroom in de plant kan als een fysisch verschijnsel worden beschreven, waarbij het transport in de plant voornamelijk plaats vindt in de xyleemvaten en de celwanden van het bladweefsel. Alleen in de endodermis wordt het water door de levende cellen getransporteerd, waarbij het vochttransport mede afhankelijk is van de stofwisseling in deze cellen. Zowel lage bodemtemperaturen als slechte aeratie kunn en daardoor het vochttransport in de wortels beïnvloeden. Deze factoren geven echter ten aanzien van de reductie in de transpiratie eenzelfde reactie als een vochttekort in de wortelzone.

De grootste weerstand in de plant treedt op in de dampfase bij de diffusie van waterdamp van de intercellulaire holien naar de externe atmosfeer. Deze weerstand is afhankelijk van de opening van de huidmondjes, die weer in verband staat met de lichtintensiteit, de bladtemperatuur en de zuigspanning in het bladweefsel.

De lichtintensiteit is bij optimale vochtvoorziening de voornaamste factor die de huidmondjes-opening regelt. In dit onderzoek is de gemiddelde lichtintensiteit gedurende de balansperiode als maatstaf gebruikt om dit effect te beschrijven.

De plantenfysiologische en fysische beschouwingen die door Penman en SCOFIELD (1951) zijn ontwikkeld, geven geen verklaring voor de, voor kort gras, experimenteel bepaalde waarden van de reductiefactor $f$. De sluiting van de huidmondjes gedurende de nacht heeft weinig invloed op de waarde van de transpiratie, aangezien de voor de verdamping beschikbare energie gedurende deze periode zeer klein is. Hieruit volgt, dat de factor daglengte van weinig betekenis is voor de bepaling van de waarde van de reductiefactor. Bovendien wordt in deze studie angetoond, dat de waarde van de reductiefactor in hoofdzaak wordt bepaald door het verschil in waarde van de reflectiecoëfficiënten van het gewas en van een vrij wateroppervlak.

De schijnbare diffusieweerstand van het gewas is in de berekeningen ingevoerd in verband met de geometrie van het verdampend oppervlak en de diffusieweerstand in de huidmondjes. Een gecombineerde vergelijking van de evapotranspiratie werd afgeleid, waarbij deze factor in rekening is gebracht.

Er zijn aanwijzingen dat de waarde van de schijnbare diffusieweerstand van gras bij hoge lichtintensiteit en optimale vochtvoorziening gelijk is aan nul.

Evaporatie van de interceptie van neerslag heeft een verhogend effect op de evapotranspiratie indien de schijnbare diffusieweerstand niet gelijk is aan nul. Een benadering voor de berekening van dit effect is gegeven, waarbij is aangenomen dat de evaporatie uit de grond onder een gewas met volledige bodembedekking kan worden verwaarloosd.

In Hoofdstuk V wordt de invloed van bodemfysische factoren op de evapotranspiratie besproken.

Een onderzoek van zowel literatuurgegevens als van de waarden die in deze studie zijn berekend toont aan, dat het verband tussen het capillair geleidingsvermogen en de zuigspanning in het traject van verzadiging tot een zuigspanning van 100 à $300 \mathrm{~cm}$ 
door een exponentiële functie kan worden weergegeven, waarin tevens de zuigspanning van het luchtindringingspunt in rekening wordt gebracht. De aanwezigheid van een schijnbaar niet-capillair poriënvolume in een aantal gronden, heeft weinig invloed op de beschouwingen over capillaire opstijging. Het zuigspanningstraject waarin deze exponentiële relatie geldig is varieert sterk voor uiteenlopende gronden, in afhankelijkheid van de verdeling en de grootte van de bodemdeeltjes. Uit de beschikbare gegevens blijkt dat het zuigspanningstraject toeneemt met afnemende grofheid van de grond. Dit traject is mogelijk weer kleiner bij gronden met een samengestelde structuur.

Het verband tussen het capillair geleidingsvermogen en de zuigspanning in het traject van hoge zuigspanningen kan worden weergegeven door een machtsfunctie, zoals door WIND (1955) werd voorgesteld. Uit de beschikbare gegevens bleek, dat de exponent in deze vergelijking voor sterk uiteenlopende gronden een vrijwel constante waarde heeft van 1,4 .

De gevonden resultaten geven mogelijk een aanwijzing, dat het capillair geleidingsvermogen in het lage zuigspanningstraject wordt bepaald door stroming door gevulde capillairen, terwijl in het hoge zuigspanningstraject het transport in hoofdzaak wordt bepaald door de weerstand in de oppervlakte-film over de bodemdeeltjes.

De vochtopname door de wortels is beschreven met een vergelijking die door GARDNER en EHLIG (1962) is ontwikkeld. Een berekeningsmodel werd opgesteld om geschatte waarden van de transportweerstand in de plant en van de geometriefactor van het wortelstelsel te berekenen.

De vochtonttrekking onder de effectieve wortelzone is berekend door gebruik te maken van de stationaire oplossingen van de stromingsvergelijking. De capillaire opstijging vanaf het freatisch vlak is niet sterk afhankelijk van de vochtonttrekking in de effectieve wortelzone, indien de waterstand relatief hoog is, maar wordt dan voornamelijk bepaald door de potentiële transpiratie van het gewas. De onttrekkingssnelheid van het vocht beneden de effectieve wortelzone wordt, vooral bij diepe grondwaterstanden, mede bepaald door de transpiratie in voorafgaande perioden. De invloed van de grondwaterstand op de transpiratie is afhankelijk van de voorafgaande weersomstandigheden. Om deze reden is het effect van het bodemvocht op de transpiratie beschreven door de vochttoestand in de effectieve wortelzone.

Het verband tussen de maximale hoeveelheid vocht beschikbaar voor transpiratie en de diepte van de grondwaterstand is berekend voor verschillende periode-lengten. Uit deze berekeningen volgt dat de knipklei relatief de meest droogtegevoelige grond is van de bij dit onderzoek betrokken gronden.

Door berekening is aangetoond, dat de schijnbare diffusieweerstand van het gewas voornamelijk wordt bepaald door de weerstand in de huidmondjes. Het effect van de vochttoestand op de waarde van de schijnbare diffusieweerstand is beschreven als een functie van de zuigspanning in het bladweefsel, die weer afhankelijk is van de werkelijke transpiratie, van de zuigspanning en het capillair geleidingsvermogen in de effectieve wortelzone, van de geometrie van het wortelstelsel en van de transportweerstand in de plant. 
In Hoofdstuk VI is een beschrijving gegeven van de opzet van de analyse die is gebruikt bij de bestudering van de lysimetergegevens.

De vergelijkingen die geldig zijn voor de berekening van de evapotranspiratie van gras en de evaporatie uit ingegraven verdampingspannen, zijn gecombineerd om de onzekerheden die ontstaan uit fouten in de berekende netto langgolvige uitstraling over korte perioden, uit de verwaarlozing van de warmteberging in de grond en uit de invloed van de lokale advectie, in de berekende evapotranspiratie uit te schakelen.

De gemiddelde reflectiecoëfficiënt van het gras, de invloed van de lichtintensiteit op de schijnbare diffusieweerstand van het gewas en het verband van de ruwheid van het verdampend oppervlak met de gewashoogte als wel met de windsnelheid zijn bepaald onder omstandigheden van optimale vochtvoorziening, voor balansperioden, waarin geen invloed van lokale advectie kon worden aangetoond.

Onder de gegeven proefomstandigheden kon geen verschil tussen de invloed van de lokale advectie op de potentiële evapotranspiratie van gras en op de evaporatie uit ingegraven verdampingspannen worden bewezen.

De invloed van de vochtvoorziening op de waarde van de schijnbare diffusieweerstand van gras is weergegeven als een functie van de potentiele transpiratie, van de zuigspanning en het capillair geleidingsvermogen in de effectieve wortelzone, van de geometrie van het wortelstelsel en van de transportweerstand in de plant.

$\mathrm{Er}$ is aangetoond dat de reductie in transpiratie, behalve van de waarde van de schijnbare diffusieweerstand van het gewas ook afhankelijk is van de temperatuur, de windsnelheid en de ruwheid van het verdampend oppervlak. De reductie neemt voor een optredend vochttekort toe, bij een gegeven waarde van de schijnbare diffusieweerstand, bij toename van de oppervlakte ruwheid en van de windsnelheid, terwijl de reductie kleiner wordt bij een toename van de temperatuur.

Het is mogelijk om het verband te berekenen tussen de potentiële evapotranspiratie en de, volgens de vergelijking van Penman berekende of met ingegraven vcrdampingspannen gemeten, evaporatie van een vrij water oppervlak. Deze berekening is uitgevoerd voor de bepaling van het schijnbare verband tussen de potentiële evapotranspiratie van lucerne en de berekende evaporatie van een vrij wateroppervlak onder de klimatologische omstandigheden in Tunesië.

Deze methode kan vooral van belang zijn voor het bepalen van de potentiële waterbehoefte van verschillende gewassen bij het ontwerpen van irrigatieprojecten onder uiteenlopende klimatologische omstandigheden. 


\section{List of symbols}

Definitions of symbols used in one paragraph only, mainly in the discussion on relations presented in literature, are given in the paragraph concerned and not in this list. The letters $a, b, c, \alpha$ and $\beta$ are used for any given constant. In some cases two dimensions are given, separated by a semicolon.

$A_{c}$ factor for the effect of local advection on $\mathrm{mm} \mathrm{H}_{2} \mathrm{O} \cdot \mathrm{mm} \mathrm{Hg} \cdot{ }^{\circ} \mathrm{C}^{-1} \cdot$ day $^{-1}$ evapotranspiration

$A_{w}$ factor for the effect of local advection on $\mathrm{mm} \mathrm{H} \mathrm{H}_{2} \mathrm{O} \cdot \mathrm{mm} \mathrm{Hg} \cdot{ }^{\circ} \mathrm{C}^{-1} \cdot$ day $^{-1}$ evaporation from sunken pans

b geometry- and activity-factor of the root $\mathrm{cm}$; atm system

$d$ zero-plane displacement in relation to $\mathrm{cm}$ earth surface

$E$ evapotranspiration

$E_{a} \quad 0.182 u\left(\varepsilon_{a}-e_{a}\right)$

$E_{a}^{\prime} \quad f\left(z_{0}, d\right) u\left(\varepsilon_{a}-e_{a}\right)$

$E_{I} \quad$ evaporation of intercepted precipitation

$E_{o} \quad$ evaporation from a free water surface

$$
\begin{aligned}
& \mathrm{mm} \cdot \mathrm{day}^{-1} ; \mathrm{g} \cdot \mathrm{sec}^{-1} \cdot \mathrm{cm}^{-2} \\
& \mathrm{~mm} \cdot \mathrm{day}^{-1} \\
& \mathrm{~mm} \cdot \mathrm{day}^{-1} \\
& \mathrm{~mm} \cdot \mathrm{day}^{-1} \\
& \mathrm{~mm} \cdot \mathrm{day}^{-1} \\
& \mathrm{~mm} \cdot \mathrm{day}^{-1}
\end{aligned}
$$

$E_{p}^{\prime} \quad$ evaporation from a wet surface with the same aerodynamic and reflective properties as short grass

$E_{T} \quad$ transpiration

$E_{T}^{r e}$ real transpiration

$E_{T}^{\text {pot }}$ potential transpiration

$e_{a} \quad$ actual vapour pressure at $2 \mathrm{~m}$ height

$e_{i n t}$ actual vapour pressure in the sub-stomatal cavities

$e_{s} \quad$ actual vapou pressure at the evaporating surface

$f \quad$ reduction factor of Penman

$G \quad$ storage of heat in the crop

$H_{a}$ theoretical maximum shortwave radiation

$\mathrm{mm} \cdot$ day $^{-1}$

$\mathrm{mm} \cdot \mathrm{day}^{-1}$

$\mathrm{mm} \cdot \mathrm{day}^{-1}$

$\mathrm{mm} \mathrm{Hg}$

$\mathrm{mm} \mathrm{Hg}$ received if no atmosphere is present (Angot value).

$H_{n t}$ net radiation

$\mathrm{cal} \cdot \mathrm{day}^{-1} \cdot \mathrm{cm}^{-2}$

$\mathrm{cal} \cdot \mathrm{day}^{-1} \cdot \mathrm{cm}^{-2}$

$\mathrm{mm} \mathrm{Hg}$

$\mathrm{cal} \cdot \mathrm{day}^{-1} \cdot \mathrm{cm}^{-2}$ 
${ }^{n} H_{l o}$ net longwave radiation

$H_{\text {sh }}$ global shortwave radiation

${ }^{\max } H_{s h}$ maximum shortwave radiation received on clear days

$K \quad$ sensible heat flux density to the atmosphere

$K_{H} \quad$ eddy transfer factor for heat

$K_{M}$ eddy transfer factor for momentum

$K_{V}$ eddy transfer factor for water vapour

$k \quad$ capillary conductivity

$k_{0} \quad$ capillary conductivity at $\psi=0$ (extrapolated)

$k_{3} \quad$ hydraulic conductivity

$L \quad$ latent heat of vaporization

$N$ maximum possible duration of bright sunshine

$n \quad$ actual duration of bright sunshine

$P \quad$ precipitation

$p \quad$ atmospheric air pressure

$q \quad$ specific humidity

$R_{a} \quad$ diffusion resistance in the external atmosphere

$R_{c} \quad$ apparent diffusion resistance of the crop

$R_{c}^{i} \quad$ apparent diffusion resistance of the crop in relation to light intensity

$R_{c}^{\psi} \quad$ apparent diffusion resistance of the crop in relation to the suction in the leaf tissue

$R_{s} \quad$ stomatal diffusion resistance

$R_{p l} \quad$ resistance for liquid flow through the plant

$r$ reflection coefficient

$r_{c}$ reflection coefficient of a crop

$r_{w}$ reflection coefficient of water

$S \quad$ sensible heat flux density to the soil

$T$ temperature

$T_{a} \quad$ air temperature at $2 \mathrm{~m}$ height

$T_{s} \quad$ temperature at the evaporating surface

$T^{\prime} \quad$ absolute temperature

$u \quad$ wind velocity at $2 \mathrm{~m}$ height

$u_{z} \quad$ wind velocity at height $z$

$v \quad$ flow velocity of water in the soil

$z \quad$ height above zero level (earth surface, groundwater table)

$z_{0} \quad$ roughness length of the evaporating surface $\mathrm{cal} \cdot \mathrm{day}^{-1} \cdot \mathrm{cm}^{-2}$

$\mathrm{cal} \cdot \mathrm{day}^{-1} \cdot \mathrm{cm}^{-2}$

$\mathrm{cal} \cdot$ day $^{-1} \cdot \mathrm{cm}^{-2}$

$\mathrm{cal} \cdot \mathrm{day}^{-1} \cdot \mathrm{cm}^{-2}$

$\mathrm{cm}^{2} \cdot \mathrm{sec}^{-1}$

$\mathrm{cm}^{2} \cdot \mathrm{sec}^{-1}$

$\mathrm{cm}^{2} \cdot \mathrm{sec}^{-1}$

$\mathrm{cm} \cdot$ day $^{-1}$

$\mathrm{cm} \cdot$ day $^{-1}$

$\mathrm{cm} \cdot$ day $^{-1}$

$10^{-1} \cdot \mathrm{cal} \cdot \mathrm{cm}^{-3}$

hours

hours

$\mathrm{mm} \cdot$ day $^{-1}$

$\mathrm{mm} \mathrm{Hg}$

$\mathrm{g}_{\mathrm{H}_{2} \mathrm{O}} \cdot \mathrm{g}_{\mathrm{air}}^{-1}$

$\mathrm{mm} \mathrm{Hg} \cdot$ day $\cdot \mathrm{mm}^{-1} ; \mathrm{sec} \cdot \mathrm{cm}^{-1}$

$\mathrm{mm} \mathrm{Hg} \cdot$ day $\cdot \mathrm{mm}^{-1} ; \mathrm{sec} \cdot \mathrm{cm}^{-1}$

$\mathrm{mm} \mathrm{Hg} \cdot$ day $\cdot \mathrm{mm}^{-1} ; \mathrm{sec} \cdot \mathrm{cm}^{-1}$

$\mathrm{mm} \mathrm{Hg} \cdot \mathrm{day} \cdot \mathrm{mm}^{-1} ; \mathrm{sec} \cdot \mathrm{cm}^{-1}$

$\mathrm{mm} \mathrm{Hg} \cdot$ day $\cdot \mathrm{mm}^{-1} ; \mathrm{sec} \cdot \mathrm{cm}^{-1}$

$\mathrm{cm} \cdot$ day $\cdot \mathrm{mm}^{-1} ; \mathrm{atm} \cdot$ day $\cdot \mathrm{mm}^{-1}$

$\mathrm{cal} \cdot \mathrm{day}^{-1} \cdot \mathrm{cm}^{-2}$

${ }^{\circ} \mathrm{C}$

${ }^{\circ} \mathrm{C}$

${ }^{\circ} \mathrm{C}$

${ }^{\circ} \mathrm{K}$

$\mathrm{m} \cdot \mathrm{sec}^{-1}$

$\mathrm{cm} \cdot \mathrm{sec}^{-1} ; \mathrm{m} \cdot \mathrm{sec}^{-1}$

$\mathrm{cm} \cdot$ day $^{-1} ; \mathrm{mm} \cdot \mathrm{day}^{-1}$

cm

cm 
$\gamma$ constant of wet and dry bulb hygrometer $\mathrm{mm} \mathrm{Hg} \cdot{ }^{\circ} \mathrm{C}^{-1}$ equation (psychrometer constant)

$\Delta$ slope of the temperature-vapour pressure $\mathrm{mm} \mathrm{Hg} \cdot{ }^{\circ} \mathrm{C}^{-1}$ curve at temperature $T_{a}$

$\varepsilon_{a} \quad$ saturated vapour pressure at temperature $\mathrm{mm} \mathbf{H g}$ $T_{a}$

$\varepsilon_{i m} \quad$ saturated vapour pressure below the zero- $\mathrm{mm} \mathrm{Hg}$ plane at temperature $T_{s}$

$\varepsilon_{s} \quad$ saturated vapour pressure at the evapo- $\mathrm{mm} \mathrm{Hg}$ rating surface at temperature $T_{s}$

$\rho \quad$ air density

$\mathrm{g} \cdot \mathrm{cm}^{-3}$

$\tau$ momentum

$\psi \quad$ suction of soil moisture

$\psi_{a} \quad$ suction at the air entry point

$\psi_{1} \quad$ suction in the leaf tissue

$\psi_{i}^{\text {re }}$ real suction in the leaf tissue

$\psi_{i}^{\text {pot }}$ potential suction in the leaf tissue

$\left(\mathrm{g} \cdot \mathrm{cm} \cdot \mathrm{sec}^{-1}\right) \cdot \mathrm{sec}^{-1} \cdot \mathrm{cm}^{-2}$

$\mathrm{cm}$; atm

$\mathrm{cm}$

$\mathrm{cm} ;$ atm

$\mathrm{cm}$; aim

$\psi_{\max }$ maximum suction to which equations (44) $\mathrm{cm}$ and (45) hold

$\psi_{r} \quad$ suction at the root surface

cm; atm 


\section{References}

Andel-Aziz, M. H., S. A. TAYlor and G. L. Ashcroft, 1964. Influence of advective energy on transpiration. Agron. J. 56: 139-142.

Abd El Rahman, A. A., P. J. C. Kuiper and J. F. Bierhuizen, 1959. Preliminary observations on the effect of soil temperature on transpiration and growth of young tomato plants under controlled conditions. Med. Landbouwhogeschool 59, 15.

ARISZ, W. H., R. J. Helder and R. VAN NIE, 1951. Analysis of the exudation process in tomato plants. J Exp. Bot. 2: 257-297.

Ashburn, E. V. and R. G. Weldon. 1956. Spectral diffusive reflectance of desert surfaces. $J$. Opt. Soc. Am. 46: 583-586.

Bavel, C. H. M. van, L. J. Fritschen and W. E. Reeves, 1963. Transpiration by Sudangrass as an externally controlled process. Science 141: 269-270.

BEARd, J. S., 1962. Rainfall interception by grass. Sd. Afr. Bosboutijdskriff 42: 12-15.

BlaneY, H. F, and W. D. CrudDle. 1950. Determining water requirements in irrigated areas from climatological and irrigation data. U.S. Soil Cons. Serv. SCS - T.P. 96.

BonYthon, C. W., 1950. Evaporation studies using some South Australian data. Trans. Roy. Soc. South Austr. 73: 198-219.

BrewIG, A., 1937. Permeabilitätsänderungen der Wurzelgewebe, die vom Spross aus beeinflusst werden. Z. Bot. 31: 481-540.

Broadbent, L., 1950. The microclimate of the potato crop. Quart. J. Roy. Met. Soc. 76: 439-454.

Brouwer, R., 1954. The regulating influence of transpiration and suction tension on the water and salt uptake by the roots of intact Vicia Faba plants. Acta Bot. Neerl. 3: 264-312.

Burgy, R. H. and C. R. Pomeroy, 1958. Interception losses in grassy vegetation. Trans. Am. Geoph. Un. 39: 1095-1100.

Businger, J. A., 1956. Some remarks on Penman's equation for the evapotranspiration. Neth. $J$. Agric. Sci. 4: 77-80.

ButiJ, J., 1961. Bodembehandeling in de fruitteelt. Versl. Landb. Onderz. 66.7.

CALDER, K. L., 1939. A note on the constancy of horizontal turbulent shearing stress in the lower layers of the atmosphere. Quart. J. Roy. Met. Soc. 65: 537-541.

CARR, D. J. and D. F. GAFF, 1961. The role of the cell-wall in the water relations of leaves. Arid. Zone Res. 16: 117-125.

Chrustensen, H. R., 1944. Capillary conductivity curves for three prairy soils. Soil Sci. 57: 381-391.

ClARK, O. R., 1940. Interception of rainfall by prairy grasses, weeds and certain crop plants. Ecological Monograph. 10: 245-277.

COVEY, W. and M. E. Bloodworth, 1962. Mathematical study of the flow of water to plant roots. Texas Agr. Exp. Sta. MP-599.

Crawford, T. V., 1965. Moisture transfer in free and forced convection. Quart. J. Roy. Met. Soc. 91: 18-27.

Deacon, E. L., 1949. Vertical diffusion in the lowest layers of the atmosphere. Quart. J. Roy. Met. Soc. 75: 89-103.

DeACON, E. L., 1954. Some measurements of the shearing stress and its variation with height in the lowest 100 feet of the atmosphere. Proc. Toronto Met. Conf.: 238-239.

DeACON, E. L., 1959. The measurement of turbulent transfer in the lower atmosphere. Adv. in Geoph. 6: 211-228. 
Deacon, E. L. and W. C. Swinbank, 1958. Comparison between momentum and water vapour transfer. Arid Zone Res. 11: 38-41.

Deacon, E. L., C. H. B. Priestly and W. C. Swinbank, 1958. Evaporation and the waterbalance. Arid Zone Res. 10: 9-34.

Dep. Phys. Met. Agric. Univ. Wageningen, 1957-1963. Meteorologische maandgrafieken.

DRINKWATER, W. O. and B. E. JANES, 1957. Relation of potential evapotranspiration to environment and kind of plant. Trans. Am. Geoph. Un. 38: 524-528.

EhLIG, C. F. and W. R. GARDNer, 1964. Relationship between transpiration and the internal water relations of plants. Agron. J. 56: 127-130.

EHRLER, W. L., 1963. Water absorption of alfalfa as affected by low root temperature and other factors of a controlled environment. Agron. J. 55: 363-366.

England, C. B., 1963. Water use by several crops in a weighing lysimeter. Agron. J. 55: 239-242.

Ertel, H., 1933. Beweis der Wilh. Schmitschen kompensierten Potenzformeln für Austausch und Windgeschwindigkeit in den bodennahen Luftschichten. Met. Z. 50; 386-388.

Fleming, P. M., 1964. Evaporimeter relationships at Griffith N.S.W. Trans. Inst. Civil Eng. Austr. March 1964: 15-24.

GaAstra, P, 1959. Photosynthesis of crop plants as influenced by light, carbon dioxide, temperature and stomatal diffusion resistance. Med. Landbouwhogeschool: 59.13

Gardner, W., O. W. Israelsen, N. E. Edlefsen and H. Clyde, 1922. The capillary potential function and its relation to irrigation practics. Phys. Rev. 20 Ser. 2: 196.

Gardner, W. R., 1958. Some steady state solutions of the unsaturated moisture flow equation with application to evaporation from a watertable. Soil Sci. 85: 228-232.

GARDNER, W. R., 1960. Dynamic aspects of water availability to plants. Soil Sci. 89: 63-73.

GARDNER, W. R., 1964. Relation of root distribution to water uptake and availability. Agron. J. S6: $41-45$.

GARDNER, W. R., and C. F. EHLIG, 1962. Some observations on the movement of water to plant roots. Agron. J. 54: 453-456.

GARDNER W. R. and C. F. EHLIG, 1963. The influence of soil water on transpiration by plants. J. Geoph. Res. 68: 5719-5724.

Gardner, W. R. and M. Fireman, 1958. Laboratory studies of evaporation from soil columns in the presence of a water table. Soil Sci. 85: 244-249.

Goss, J. R. and F. A. Brooks, 1956. Constants for empirical expressions for downcoming atmospheric radiation under cloudiess sky. J. Met. 13: 482-488.

Halstead, M. H. and W. CoveY, 1957. Some meteorological aspects of evapotranspiration. Soil Sci. Soc. Am. Proc. 21: 461-464.

HONERT, T. H. VAN DEN, 1948. Water transport in plants as a catenary process. Disc. Faraday Soc. 3: 146-153.

Hounam, C. E., 1958. Evaporation pan coefficients in Australia. Arid Zone Res. 11: 52-64.

Kohler, M. A., T. J. Nordenson and W. E. Fox, 1955. Evaporation from pans and lakes. U.S. Dep. Comm. Res. Paper 38.

Kramer, P. J., 1938. Root resistance as a cause of the absorption lag. Am. J. Bor. 25: 110-113.

KRAMER, P. J., 1939. The forces concerned in the intake of water by transpiring plants. Am. J. Bot. 26: 784-791.

Kramer, P. J., 1941. Soil moisture as a limiting factor for active absorption and root pressure. Am. J. Bot. 28: 446-451.

Kramer, P. J., 1945. Absorption of water by plants. Bot. Rev. 11: 310-355.

KrAmer, P. J., 1956. Physical and physiological aspects of water absorption. In: W. Ruhland Handb. Pflanzenphys. III. Springer-Verlag, Berlin: 124-159.

KUIPER, P. J. C., 1961. The effects of environmental factors on the transpiration of leaves, with special reference to stomatal light response. Med. Landbouwhogeschool 61.7.

KuIPER, P. J. C., 1964. Water uptake ofhigher plants as affected by root temperature. Med. Landbouwhogeschool 64.4 . 
Kuiper, P. J. C. and J. F. Bierhuizen, 1958. The effect of some environmental factors on the transpiration of plants under controlled conditions. Med. Landbouwhogeschool 58.11.

Lemon, E. R., A. H. Glaser and L. E. Satrerwhite, 1957. Some aspects of the relationship of soil, plant and meteorological factors to evapotranspiration. Soil Sci. Soc. Am. Proc. 21: 464-468.

Letey, J., O. R. Lunt, L. H. Stolzy and J. Szuszkiewicz, 196I. Plant growth, water use and nutritional response to rhizosphere differentials of oxygen concentration. Soil Sci. Soc. Am. Proc. 25: 183-186.

Leven, J. A. VAN 'T et M. H. HAdDAd, 1963. Rapport annuel sur le fonctionnement des stations climatologiques de la Basse Vallée de la Medjerda. Année 1962. Office de la Mise en Valeur de la Vallée de la Medjerda, Rep. Tunisienne.

LeVen, J. A. VAN 'T et M. H. HADdad, 1964a. Rapport annuel sur le fonctionnement des stations climatologiques de la Basse Vallée de la Medjerda. Année 1963. Office de la Mise en Valeur de la Vallee de la Medjerda. Rep. Tunisienne.

LEVEN, J. A. VAN 'T et M. A. HADDAD, 1964b. Compte rendu des recherches à la station expérimentale de Bejaoua. Années 1962 et 1963. Office de la Mise en Valeur de la Vallée de la Medjerda, Rep. Tunisienne.

LevitT, J., 1956. The physical nature of transpiration pull. Plant Phys. 31: 248-251.

LIESHOUT, J. W. VAN, 1957. De invloed van de wortelontwikkeling op de waterhuishouding van een hoge zandgrond. Landbouwk. Tijdschr. 67: 165-179.

Lipps, R. C. and R. L. Fox, 1964. Root activity of sub-irrigated alfalfa as related to soil moisture, temperature and oxygen supply. Soil Sci. 97: 4-12.

MakKINK, G. F., 1953. Een nieuw lysimeterstation. Water 37: 159-163.

Makkink, G. F., 1955. Toetsing van de berekening van de evapotranspiratie volgens Penman. Landbouwk. Tijdschr. 67: 267-282.

Makxink, G. F., 1957. Testing the Penman formula by means of lysimeters. J. Inst. Water Eng. 11: 277-288.

Makkink, G. F., 1960. De verdamping uit vegetaties in verband met de formule van Penman. Versl. en Med. Comm. Hydr. Onderz. T.N.O. 4: 90-115.

Makkink, G. F., 1962. Vijf jaren lysimeteronderzoek. Versl. Landb. Onderz. 68.1.

Makkink, G. F. en H. D. J. van HeEmST, 1962. Het berekenen van de waterbalans van de Schroeweg polder op Walcheren. Versl. Landb. Onderz. 68.2

MARlATt, W. E., 1961. The interactions of microclimate, plant cover and soil moisture content affecting evapotranspiration rates. Dep. Atm. Sci. Colorado State Univ. Atm. Techn. Paper 23.

McllroY, I. C., and D. E. ANGus, 1964. Grass, water and soil evaporation at Aspendale. Agric. Met. 1: 201-224.

MCMillan, W. D. and R. H. BuRGY, 1960. Interception loss from grass. J. Geoph. Res. 65: 2389-2394.

Mees, G. C. and P. E. Weatherly, 1957. The mechanism of water absorption by roots. Proc. Roy Soc. London B 147: 367-391.

MILlAR, B. D., 1964. Effect of local advection on evaporation rate and plant water status. Austr. J. Agric. Res. 15: 85-90.

Milthorpe, F. L., 1960. The income and loss of water in arid and semi-arid zones. Arid Zone Res, 15: 9-36.

MonterTH, J. L., 1956. Evaporation at night. Neth. J. Agric. Sci. 4: 34-38.

MoNTEITH, J. L., 1958. The heat balance of soil beneath crops. Arid Zone Res. II: 123-128.

MONTEITH, J. L., 1959. The reflection of shortwave radiation by vegetation. Quart. J. Roy. Met. Soc. 85: $386-392$.

MONTEITH, J. L., 1963. Gax exchange in plant communities. In: Evans, E. T., Environmental control of plant growth. Academic Press, New York. 95-112.

MONTEITH, J. L. and G. SzEICZ, 1962. Radiative temperature in the heat balance of natural surfaces. Quart. J. Roy. Met. Soc. 88: 496-507.

Moore, R. E., 1939. Water conduction from shallow tables. Hilgardia 12: 383-426. 
Nielsen, D. R., D. Kirkham and E. R. Perrier, 1960. Soil capillary conductivity, comparison of measured and calculated values. Soil Sci. Soc. Am. Proc. 24: 157-160.

PAsquill, F., 1949a. Eddy diffusion of water vapour and heat near the ground. Proc. Roy. Soc. London A 198: 116-140.

PASQunl, F., 1949b. Some estimates of the amount and diurnal variation of evaporation from a clay land pasture in fair spring weather. Quart. J. Roy. Met. Soc. 75: 249-256.

Pasquill, F., 1950a. The aerodynamic drag of grassland. Proc. Roy. Soc. London A 202: 143-153.

PasquiLL, F., 1950b. Some further considerations of the measurement and indirect evaluation of natural evaporation. Quart. J. Roy. Met. Soc. 76: 287-301.

Penman, H. L., 1948. Natural evaporation from open water, bare soil and grass. Proc. Roy. Soc. London A 193: 120-145.

Penman, H. L., 1956. Evaporation. An introductory survey. Neth. J. Agric. Sci. 4: 9-29.

Penman, H. L. and R. K. Schofield, 1951. Some physical aspects of assimilation and transpiration. Proc. Symp. nr. V Soc. Exp. Biol.: 115-129.

Philip, J. R., 1957. The physical principles of soil water movement during the irrigation cycle. Proc. 3rd Int. Congr. Irr. and Drain: 8.125-8.154.

Ramdas, L. A., 1957. Evaporation and potential evapotranspiration over the Indian subcontinent. Indian J. Agric. Sci. 27: 137-149.

Richards, L. A., 1931. Capillary conduction of liquids through porous media. Physics 1: 318-333.

Richards, L. A., and D. C. MoORE, 1952. Influence of capillary conductivity and depth of wetting on moisture retention in soil. Trans. Am. Geoph. Un. 33: 531-540.

Richards, L. A. and B. D. Wilson, 1936. Capillary conductivity measurements in peat soils. J. Am. Soc. Agron. 28: 427-431.

Richards, S. J. and L. V. WEeKs, 1953. Capillary conductivity values from moisture yield and tension measurements on sojl columns. Soil Sci. Soc. Am. Proc. 17: 206-209.

RIDER, N. E., 1954a. Eddy diffusion of momentum, water vapour and heat near the soil. Phylos. Trans. A 246: 481-501.

RIDER, N. E., 1954b. Evaporation from an oatfield. Quart. J. Roy. Met. Soc. 80: 198-211.

RIDER, N. E., 1957. Water losses from various land surfaces. Quart. J. Roy. Met. Soc. 83: 181-193.

RIDER, N. E. and C. D. Robinson, 1951. A study of the transfer of heat and water vapour above a surface of short grass. Quart. J. Roy. Mer. Soc. 77: 375-401.

Rider, N. E., J. R. PhiljP and E. F. Bradley, 1963. The horizontal transport of heat and moisture: A micrometeorological study. Quart. J. Roy. Met. Soc. 89: 507-531.

Rutema, P. E., 1959. Calculation methods of potential evapotranspiration. Inst. Land and Water Man. Res. Techn. Bull 7.

Robinson, G. D., 1950. Notes on the measurement and estimation of atmospheric radiation. Quart. J. Roy. Mes. Soc. 76: 37-51.

Rubin, J., R. Steinhardt and P. RenNiger, 1964. Soil water relations during rain infiltration II. Moisture content profiles during rains of low intensities. Soil Sci. Soc. Am. Proc. 28: 1-5.

RyHiner, A. H. and P. E. Rutema, 1963. Berekening van de gemiddelde grootte van de verdamping van naaldhout volgens de methode van Mcllroy. Inst. Cultuurtechn. Waterhuish. Nota 213.

SCHOlte UBING, D. W., 1959. Over stralingsmetingen, de warmtebalans en de verdamping van gras. Med. Landbouwhogeschool 59.10.

SHEPPARD, P. A., 1958. Transfer across the earth's surface and through the air above. Quart.J. Roy. Met. Soc. 84: $205-224$.

SLATYER, R. O., 1957. The influence of progressive increases in total soil moisture stress on transpiration, growth and internal water relationships of plants. Austr. J. Biol. Sci. 10: 320-336.

Slatyer, R. O. and J. F. Bifrhuizen, 1964. Transpiration from cotton leaves under a range of environmental conditions in relation to internal and external diffusive resistances. Austr. J. Biol. Sci. 17: 115-130.

Sl.ATYer, R. O. and I. C. Mcllrox, 1961. Practical microclimatology. Unesco. 
StÅlfelt, M. G., 1956. Die stomatäre Transpiration und die Physiologie der Spaltöffnungen. In: Ruhland, W. Handb. Pflanzenphys. III. Springer-Verlag, Berlin: 351-421.

Stanhild, G., 1958. The accuracy of meteorological estimates of evapotranspiration. J. Inst. Water Eng. 12: 377-383.

Stanhile, G., 1961. A comparison of methods calculating potential evapotranspiration from climatic data. Isr. J. Agric. Res. 11: 159-171.

Staple, W. J. and J. J. Lehane, 1954. Movement of moisture in unsaturated soils. Can. J. Agric. Sci. 34: 329-342.

SUOMI, V. E. and C. B. TANNER, 1958. Evapotranspiration estimate from heat-budget measurement over a field crop. Trans. Am. Geoph. Un. 39: 298-304.

SutTon, O. G., 1953. Micrometeorology. McGraw Hill Book Comp., New York.

SwINBANK, W. C., 1951. The measurements of vertical transfer of heat and water vapour by eddies in the lower atmosphere with some results. J. Met. 8: 135-145.

SwINBank, W. C., 1955. An experimental study of eddy transports in the lower atmosphere. C.S.I.R.O. Div. Met. Phys. Techn. Paper 2.

TALSMA, T., 1963. The control of saline groundwater. Med. Landbouwhogeschool 63.10.

TANner, C. B., 1960. Energy balance approach to evaporation from crops. Soil Sci. Soc. Am. Proc. 24: $1-9$.

TANNER, C. B. and E. R. Lemon, 1962. Radiant energy utilised in evapotranspiration. Agron. J. 54: 207-212.

TANner, C. B., and W. L. Pelton, 1960. Potential evapotranspiration estimates by the approximate energy balance method of Penman. J. Geoph. Res. 65: 3391-3413.

TAYLOR, R. J., 1960. Similarity theory in the relation between fluxes and gradients in the lower atmosphere. Quart. J. Roy. Met. Soc. 86: 67-78.

TAYLOR, S. A. and J. L. HAdDOCX, 1956. Soil moisture availability related to power required to remove water. Soil Sci. Soc. Am. Proc. 20: 284-288.

TEW, R. K., S. A. TAYLOR and G. L. AshCrofT, 1963. Influence of soil temperature on transpiration under various environmental conditions. Agron. J. 55: 558-560.

ThoRnthwaIre, C. W., 1948. An approach toward a rational classification of climate. Geogr. Rev. 38: 55-94.

Thornthwaite, C. W. and B. Holzman, 1939. The determination of evaporation from land and water surfaces. Mon. Weather Rev. 67: 4-11.

ThORNTHWAite, C. W. and B. HolzMAN, 1942. Measurement of evaporation from land and water surfaces. U.S.D.A. Techn. Bull. 817.

Turc, L., 1954-1955. Le bilan d'eau des sols: relations entre les précipitations, l'évaporation et l'écoulement. Ann. Agron. 5: 491-595; et 6: 5-131.

VaAdia, Y., F. C. Raney and R. M. Hagan, 1961. Plant water deficits and physiological processes. Ann. Rev. Plant Phys. 12: 265-292.

VAzQUEZ, R. and S. A. TAYLOR, 1958. Similated root distribution and water removal rates from moist soil. Soil Sci. Soc. Am. Proc. 22: 106-1 10.

VISSER, W. C., 1959. Crop growth and availability of moisture. Inst. Land and Water Man. Res. Techn. Bull. 6.

VISSER, W. C., 1963. Soil moisture content and evapotranspiration. Inst. Land and Water Man. Res. Techn. Bull. 31.

VIsSER, W. C., 1964. Moisture requirements of crops and rate of moisture depletion of the soil. Inst. Land and Water Man. Res. Techn. Bull. 32.

VRIES, D. A. DE, 1953. Natuurkundige beschouwingen omtrent de diffusieweerstand en het warmtegeleidingsvermogen van gronden. Landbouwk. Tijdschr. 65: 676-683.

VRIES, D. A. DE, 1955. Solar radiation at Wageningen. Med. Landbouwhogeschool 55: 277-304.

VRIES, D. A. DE, 1959. The influence of irrigation on the energy balance and the climate near the ground. J. Met. 16: 256-270.

WARNE, L. G. G., 1942. The supply of water to transpiring leaves. Am. J. Bot. 29: 875-884. 
WArtenA, L., 1959. Het klimaat en de verdamping van een meer in Centraal Irak. Med. Landbouwhogeschool 59.9.

WARTENA, L., and A. J. W. Borghorst, 1961. The energy balance of an evaporation pan and the measurement of the reflectivity of its bottom. Quart. J. Roy. Met. Soc. 87: 245-249.

WEATHerLeY, P. E., 1963. The path-way of water movement across the root cortex and leaf mesophyll of transpiring plants. In: RuTter, A. J. and F. H. WhiteheAD. The water relations of plants. Symp. British Ec. Soc.: 85-100.

WERKCOMMISSIE VOOR VERDAMPINGSONDERZOEK, 1958-1960. Verslagen inzake het verdampingsonderzoek 1958-1960.

Wesseling, J., 1957. Enige aspecten van de waterbeheersing in landbouwgronden. Versl. Landb. Onderz. 63.5.

WeSSELING J., 1960. Hulpmiddelen bij de berekening van de verdamping uit een vrij wateroppervlak. Versl, en Med. Comm. Hydr. Onderz. T.N.O. 4: 31-45.

Wux, W. R. van and D. A. DE Vries, 1954. Evapotranspiration. Neth. J. Agric. Sci. 2: 105-119.

WIJK, W. R. VAN and J. DE WILDE, 1962. Microclimate. Arid Zone Res. 18: 83-113.

Wuj, W. R. vaN, D. A. DE VRIES and R. H. A. vaN DuIN, 1953. Potential evapotranspiration. Neth. J. Agric. Sci. 1: 35-38.

WILSON, B. D. and S. J. Richards, 1938. Capillary conductivity of peat soils at different moisture tensions. J. Am. Soc. Agron. 30: 583-588.

WiND, G. P., 1955. A field experiment concerning capillary rise of moisture in a heavy clay soil. Neth. J. Agric. Sci. 3: 60-69.

WIND, G. P. and A. P. Hidoing, 1961. The soil physical basis of the improvement of clay cover soils. Neth. J. Agric. Sci. 9: 281-292.

Wind, R., 1958. The lysimeters in the Netherlands. Proc. Inform. Comm. Hydrol. Res. T.N.O. 3: 164-228.

Wind, R., 1960. De lysimeters in Nederland (II). Versl. Med. Comm. Hydrol. Onderz. T.N.O. 4: 207-271.

ZEEUW, J. W. DE, 1963. Over de werkelijkheidsbenadering van gemeten neerslagen. Landbouwk. Tijdschr. 75: 815-832. 